\title{
Nigeria: 2004 Semi-Annual Staff Report Under Intensified Surveillance
}

This 2004 semi-annual staff report under intensified surveillance for Nigeria was prepared by a staff team of the International Monetary Fund as background documentation for the periodic consultation with the member country. It is based on the information available at the time it was completed on November 8, 2004. The views expressed in this document are those of the staff team and do not necessarily reflect the views of the government of Nigeria or the Executive Board of the IMF.

The policy of publication of staff reports and other documents by the IMF allows for the deletion of market-sensitive information.

To assist the IMF in evaluating the publication policy, reader comments are invited and may be sent by e-mail to publicationpolicy@imf.org.

Copies of this report are available to the public from

International Monetary Fund • Publication Services

700 19th Street, N.W. • Washington, D.C. 20431

Telephone: (202) 6237430 • Telefax: (202) 6237201

E-mail: publications@imf.org • Internet: http://www.imf.org

Price: $\$ 15.00$ a copy

\section{International Monetary Fund Washington, D.C.}





\title{
INTERNATIONAL MONETARY FUND
}

\author{
NIGERIA

\section{Semi-Annual Staff Report Under Intensified Surveillance}

Prepared by the Staff Representatives

Approved by Michael Nowak and Carlos Muñiz

November 8, 2004

- The mid-term review was held in Abuja during September 6-13, 2004 to assess the implementation of the authorities' program for the first six months of 2004 and the near- term outlook. Staff representatives were Mr. Katz (Head), Mr. Bartsch and Ms. Gobat (all AFR), Mr. Villafuerte (FAD), Mr. Nielsen (PDR), and Mr. Thiam (Senior Resident Representative). The mission collaborated with the World Bank resident mission.

- The mission met with a range of senior officials, including Dr. (Mrs.) Okonjo-Iweala, Minister of Finance; Professor Soludo, Governor of the Central Bank of Nigeria (CBN); Mr. El-Rufai, Minister of the Federal Capital Territory; Mrs. Ezekwesili, Senior Special Assistant to the President, Mr. Agusto, Director General, Budget Office of the Federation (BOF); Ms. Omoigui, Executive Chair, Federal Inland Revenue Service (FIRS); Mr. Naiyeju, Accountant General of the Federation (OAGF); and Dr. Mansur, Director General, Debt Management Office (DMO); and other senior officials. The mission also met with representatives of the oil sector and the international community in Nigeria.

- On July 16, 2004, the Executive Board concluded the 2004 Article IV consultation discussions with Nigeria. Executive Directors welcomed the improvement in prospects for sustained adjustment and economic reform and, in particular, the articulation of a homegrown reform agenda-National Economic Empowerment and Development Strategy (NEEDS). Directors concurred with the broad reform priorities and stressed that consistent and determined implementation of the reform agenda was essential for Nigeria to confront successfully the daunting economic and social challenges that lay ahead. They generally endorsed the proposed intensified surveillance.

- The intensified surveillance framework involves quarterly staff visits and the preparation of a six-monthly report for the information of the Executive Board. The implementation of the authorities' program will be assessed against their quarterly budget and monetary targets and their matrix of structural reforms, as indicated in the 2004 Article IV consultation staff report (IMF Country Report No. 04/239, Tables 7, 8a, 8b, and Appendix VII). This is the first report, assessing implementation of the authorities' program for the first six months of 2004.

- Further information about Fund and World Bank relations with Nigeria is attached (Appendices I and II, respectively), as are an update of the core reform measures of the authorities' NEEDS policy matrix (Appendix III), and a tentative work program (Appendix IV). 


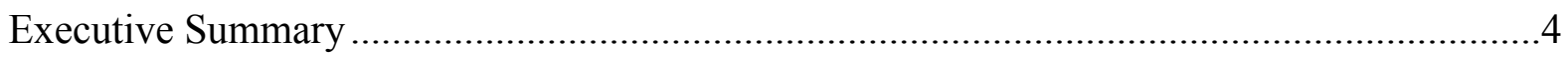

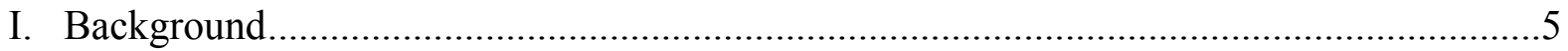

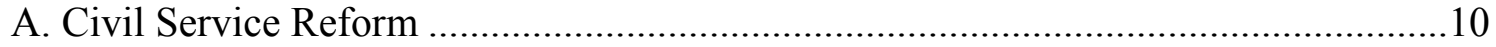

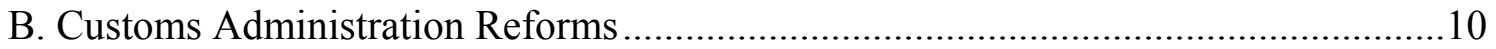

C. Procurement and Due Process Reforms ............................................................11

D. Transparency and Extractive Industries Transparency Initiative (EITI) Reforms .....11

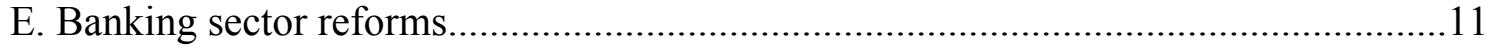

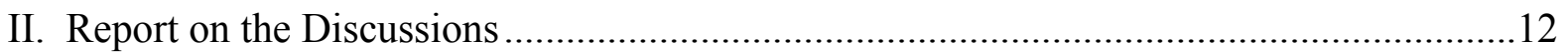

A. Short-term Outlook and Immediate Policy Challenges ..........................................12

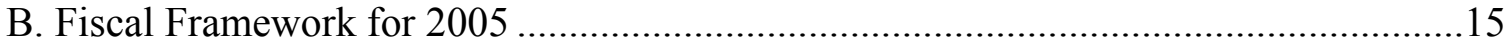

C. Technical Assistance and Capacity Building .......................................................16

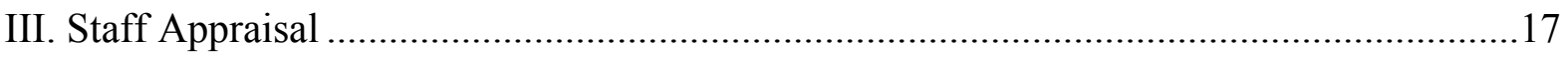

Figures

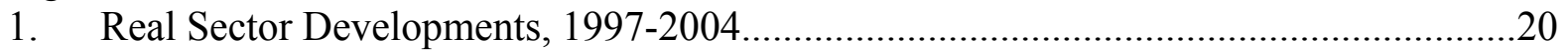

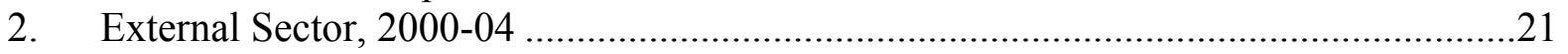

3. Consolidated Government Operations, 2000-04..................................................22

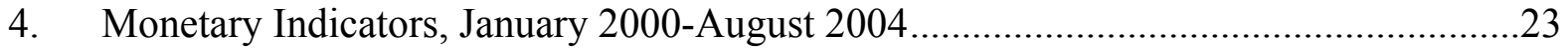

Tables

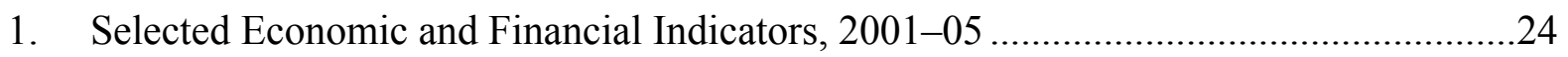

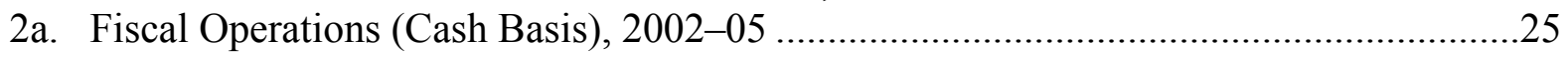

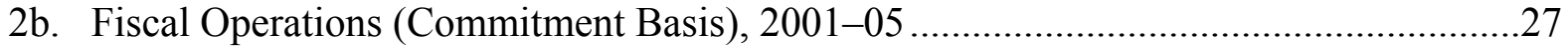

2c. Fiscal Accounts, Federal Government Budget, 2003-05 .........................................29

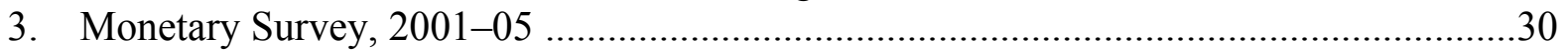

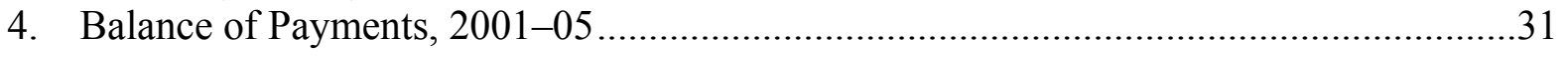

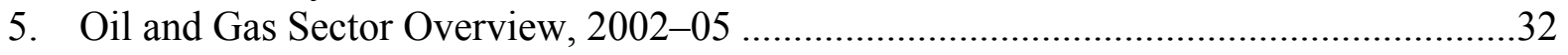

6. Quarterly Federal Government Budget (Cash Basis), Authorities' Program, 2004 .........33

7a. Central Bank of Nigera's 2004 Program: Monetary

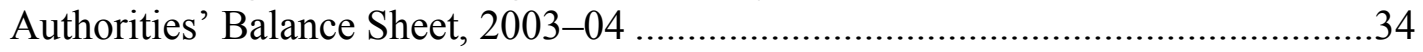

7b. Central Bank of Nigeria's 2004 Revised Monetary Program:

Monetary Survey, 2003-2004. 
Appendices

I. Relations with the Fund Report on the Discussions ...................................................36

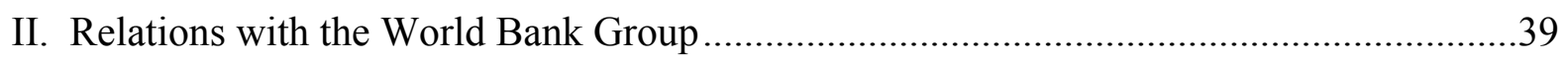

III.Authorities'Core Reform Program_-Preliminary Matrix of Measures ...........................47

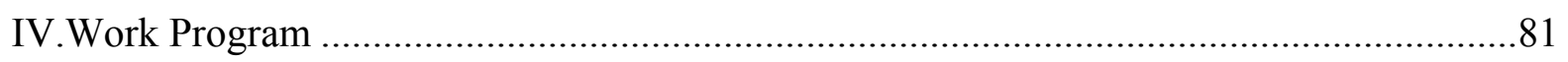




\section{Executive Summary}

Overall economic performance in the first half of 2004 was commendable. The implementation of sound macroeconomic policies, underpinned by a conservative reference oil price and savings of the oil revenue windfall, has helped stabilize the economy. Fiscal prudence along with a tight monetary policy has contributed to a buildup of international reserves and a sharp decline in inflation. These developments signal a reversal of past imprudent macroeconomic policies and will help reduce Nigeria's vulnerability to oil price shocks. They also offer hope that implementation of the reform agenda will lead to a durable transformation in economic management that will, in turn, help realize Nigeria's vast growth potential and bring about a rapid improvement in living standards.

While the outlook for the remainder of 2004 is promising, the government faces the immediate challenge of persuading all states to continue to save the oil revenue windfall. It will be essential to preserve and reinforce fiscal discipline and solidify the gains made in macroeconomic stabilization. Early passage of the Fiscal Responsibility Bill will help provide the legal underpinning for a prudent consolidated fiscal policy.

The CBN should continue to implement a credible monetary framework aimed at achieving the end-year inflation targets. Given the uncertain inflation outlook, the CBN needs to stand ready to actively manage excess liquidity consistent with its targets. Excess liquidity should be absorbed through market-determined domestic instruments. The liquidity management practices need to be strengthened to improve the effectiveness of monetary policy. Foreign exchange market reforms should be considered to bring about exchange rate unification.

Consistent implementation of structural reforms will be essential to enhancing prospects for achieving higher sustainable growth and poverty reduction. In this context, it would be important to complete the first phase of the civil service reforms and progress to the second phase in 2005. The announced banking sector reforms should help reduce the vulnerability of the financial system and enhance financial deepening. In this context, staff welcomes the CBN's request for technical assistance to ensure that the banking reforms are consistent with best practices. The privatization program needs to be accelerated to address the problem of chronic shortages and attract new investment. The announced trade liberalization by mid-2005, in the context of sound macroeconomic policies and improved infrastructure, should help spur export-oriented growth. However, capacity constraints continue to impede the implementation of the reform program. Weaknesses of the statistical system for policy formulation and analysis need to be addressed as a matter of priority.

The 2005 federal government budget should build on progress made in 2004 and remain consistent with the objectives of fiscal prudence and disinflation. Fiscal prudence is all the more important given the planned banking and foreign exchange market unification reforms. The performance of the capital budget needs to be enhanced, and measures need to be in place to ensure priority projects are selected. 


\section{BACKGROUND}

Overall macroeconomic performance in the first half of 2004 was in line with the authorities' program targets. Macroeconomic policies were consistent with the objectives of restoring macroeconomic stability and reducing Nigeria's vulnerability to oil price volatility. The fiscal stance was more restrained than programmed, and the overall surplus and the non-oil primary deficit of the consolidated government were better than targeted. All three tiers of government saved the oil revenue windfall. Monetary policy was tightened to address a liquidity overhang and curb inflationary pressures. International reserves rose sharply and inflation fell significantly. Progress was also made in implementing structural reforms.

Nigeria: Core Indicators, 2003-04 (Annual percentage changes, unless otherwise specified)

\begin{tabular}{|c|c|c|c|c|c|}
\hline & \multirow[t]{3}{*}{2003} & \multicolumn{4}{|c|}{2004} \\
\hline & & \multicolumn{2}{|c|}{ First half } & \multirow[b]{2}{*}{$\begin{array}{l}\text { Auth. } \\
\text { Prog 1/ }\end{array}$} & \multirow[b]{2}{*}{ Rev. Prog } \\
\hline & & $\begin{array}{c}\text { Auth. } \\
\text { Prog 1/ }\end{array}$ & Est. & & \\
\hline Consumer prices (end of period ) & 23.8 & $\ldots$ & 14.1 & 11.5 & 11.5 \\
\hline Federal non-oil primary balance, cash basis (in \% of non-oil GDP) & -14.6 & -14.3 & -12.1 & -13.0 & -12.8 \\
\hline Consolidated non-oil primary balance, cash basis (in \% of non-oil GDP) & -34.2 & -40.5 & -33.3 & -41.5 & -37.2 \\
\hline Broad money (12-month rate, end of period) $2 /$ & 24.1 & 0.1 & 0.1 & 16.0 & 16.0 \\
\hline Broad money (cumulative since end-2003) & $\ldots$ & 7.2 & 7.1 & 16.0 & 16.0 \\
\hline Reserve Money (12-month rate, end of period) 2/ & 16.4 & -3.7 & 0.1 & 8.2 & 8.2 \\
\hline Gross international.reserves (in billions of U.S. dollars) & 7.5 & 10.2 & 11.4 & 12.5 & 13.7 \\
\hline
\end{tabular}

1/ As reported in (IMF COUNTRY REPORT NO. 04/239).

2/ Figure for the first half is for June 2004 over June 2003

1. Overall macroeconomic performance in the first half of 2004 was in line with the authorities' objectives and targets, namely, to restore macroeconomic stability and enhance the transparency and predictability of policies. The key targets are to lower inflation to 10-13 percent by end-2004, from 24 percent at end-2003; rebuild gross international reserves to US\$12.5 billion from US\$7.5 billion at end-2003; and generate fiscal savings from the oil revenue windfall in order to contain aggregate demand pressures and provide a buffer against possible future oil price shocks.

2. Real sector developments were in line with projections. Oil prices averaged US\$33.7 per barrel for the first half of 2004 and oil production 2.5 million barrels per day (mbd). ${ }^{1}$ Other indicators of economic activity, such as land preparation and plantings, use of fertilizer and electricity consumption, and level of manufacturing inventories, suggest that the non-oil economy continues to grow strongly.

\footnotetext{
${ }^{1}$ The authorities' macroeconomic framework for 2004 assumed an oil price of US\$33.5 per barrel, average crude oil production of $2.5 \mathrm{mbd}$, and non-oil GDP growth of $4 \frac{1}{2}$ percent.
} 
3. The main fiscal targets of the authorities' program for the first half of 2004 were observed, and the fiscal stance, as measured by the non-oil primary balance of the federal government, was more prudent than programmed. Notwithstanding lower revenue, the overall surplus was larger than projected because of the slow execution of the capital budget. The main reasons for the revenue shortfall were a lower government equity share in oil production, ${ }^{2}$ the lagged passthrough of rising oil prices on oil revenue, a stronger naira, and delays in the transfer of the operating surpluses of federal government parastatals. While spending on overheads and personnel costs was in line with budget targets, only 43 percent of the capital budget targeted for the first half of 2004 was executed, largely on account of the delayed approval of the 2004 budget

\begin{tabular}{|c|c|c|c|c|}
\hline \multicolumn{5}{|c|}{$\begin{array}{l}\text { Nigeria: Federal Government Budget (Cash Basis) } \\
\text { (In billions of naira, unless otherwise specified) }\end{array}$} \\
\hline & \multirow[b]{3}{*}{2003} & \multicolumn{3}{|c|}{2004} \\
\hline & & \multicolumn{3}{|c|}{ First half } \\
\hline & & $\begin{array}{l}\text { Auth. } \\
\text { Prog. }\end{array}$ & Est. & Diff. \\
\hline Total revenue & 1,014 & 726 & 657 & -68 \\
\hline Oil revenue & 740 & 591 & 540 & -50 \\
\hline Nonoil revenue & 273 & 135 & 117 & -18 \\
\hline Total expenditure & 1,108 & 606 & 518 & -89 \\
\hline Recurrent expenditure & 841 & 441 & 424 & -18 \\
\hline Of which: personnel and pension & 368 & 219 & 219 & 1 \\
\hline overhead cost & 146 & 51 & 53 & 2 \\
\hline Capital expenditure & 267 & 165 & 94 & -71 \\
\hline Of which: domestically financed & 257 & 157 & 86 & -71 \\
\hline Overall balance & -95 & 119 & 140 & 20 \\
\hline (In percent of GDP) & -1.3 & 2.6 & 3.0 & 0.4 \\
\hline Non-oil primary balance & -593 & -346 & -295 & 51 \\
\hline (In percent of non-oil GDP) & -14.6 & -14.3 & -12.1 & 2.1 \\
\hline Memorandum items & & & & \\
\hline Non-oil primary balance, federation & $-1,390$ & -980 & -809 & 171 \\
\hline (In percent of non-oil GDP) & -34.2 & -40.5 & -33.3 & 7.2 \\
\hline Oil price (U.S. dollars per barrel) & 28.9 & 33.5 & 33.7 & 0.20 \\
\hline Oil production (millions of barrels per dollar) & 2.45 & 2.50 & 2.52 & 0.02 \\
\hline
\end{tabular}
(signed into law in April) and capacity constraints in ensuring projects met the due process requirements.

\section{The consolidated fiscal stance for the first half of $\mathbf{2 0 0 4}$ was more prudent than} programmed, because all states saved most of the oil revenue windfall. Initially only 12 states agreed to save the oil revenue windfall, but the authorities were able to persuade all states to save the windfall, resulting in fiscal savings of 3 percent of GDP for the consolidated government. As a result, the non-oil primary deficit was smaller than originally programmed and smaller than in 2003. The buildup of fiscal savings also helped lower Nigeria's net debt burden, consistent with the objectives of achieving fiscal sustainability over the medium-term and reducing fiscal vulnerability to potential oil price shocks. ${ }^{3}$

\footnotetext{
${ }^{2}$ Although oil production was in line with program targets, a higher-than-expected share of this production was supplied by fields operated under production sharing contracts and other licensing arrangements without government equity participation. The government's equity stake in the country's total crude oil production fell to 50 percent in the first half of 2004 compared with 52 percent projected.

${ }^{3}$ However, the end-2003 gross public debt figure does not include domestic contractor and pension arrears, tentatively estimated at about 20 percent of GDP, and contingent liabilities. The Debt Management Office is in the process of verifying the stock of outstanding arrears
} 
However, total savings from the oil revenue windfall fell short of projections largely because the windfall from sales of crude for domestic refining appears not to have been set aside in accounts with the CBN. ${ }^{4}$ The authorities indicated that they would review the method for calculating the windfall oil revenue to ensure consistency with the understandings of the oil price-based rule.

\section{The monetary program was broadly on track and consistent with achieving the end-year inflation} target. Fiscal restraint along with tighter liquidity management helped slow 12-month broad money growth to 8.6 percent in August from 29.1 percent a year earlier. The government's sterilization of the oil revenue windfall in savings accounts with the CBN and lower-than-targeted capital spending helped control liquidity expansion. Money market rates have increased

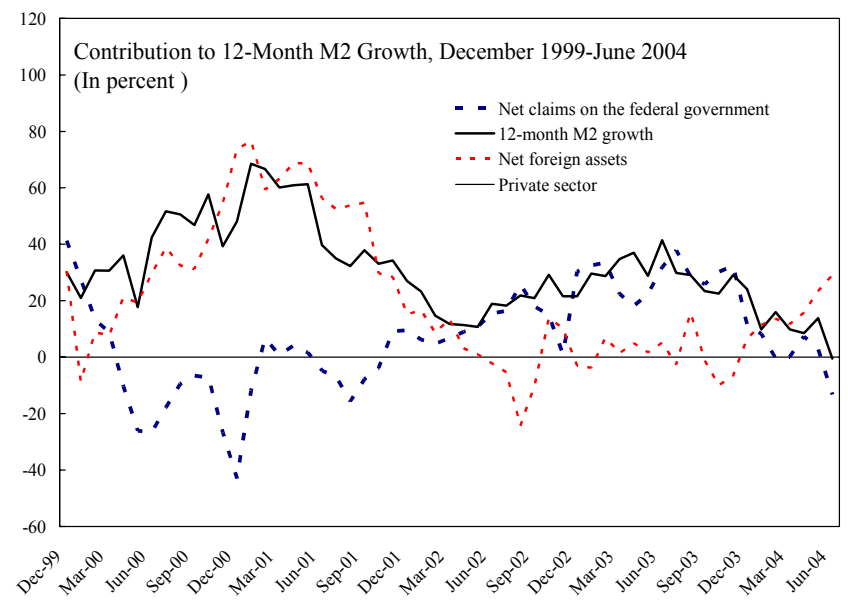
since end-2003, turning positive in real terms (Figure 4), and net credit to the government declined more than programmed. The introduction of the new clearing and settlement bank system in early April also helped mop up excess liquidity as each of the seven designated settlement banks was required to deposit N 15 billion in FGN treasury bills - as settlement collateral - with the CBN or N 105 billion in total (equivalent to about 14 percent of end2003 base money). ${ }^{5}$

and contingent liabilities, and will then assess the implications this may have on public debt burden.

${ }^{4}$ Under the oil price-based rule, all oil related revenue above the budget reference price of US\$25 per barrel should have been saved. Staff estimates that total savings fell $1 \frac{1}{2}$ percent of GDP short in the first half of 2004. This amount was distributed to the three tiers of government. While the federal government saved this extra revenue, the SLGs appear to have spent their share.

${ }^{5}$ The new system is expected to reduce banks' overdrawn accounts with the CBN, enhance monetary control, and, over time, contribute to the consolidation of the banking industry. 
6. Tighter liquidity conditions dampened foreign exchange market pressures. The naira has appreciated against the U.S. dollar by 4 percent since end-2003, and the parallel market premium has remained relatively stable at around 5 percent. Foreign exchange demand increased somewhat in the second quarter, largely because of uncertainty over the course of policies under the new governor of the $\mathrm{CBN}$ as well as the implications of the announced bank consolidation reforms (see discussion below). The CBN responded by increasing foreign exchange sales through the Dutch Auction System (DAS). DAS sales fell back to first-quarter levels following the return of investor confidence (Figure 4).

\section{The tight monetary stance and the strengthened naira helped lower inflation.}

The 12-month inflation rate declined sharply to 13 percent in August from 23.8 percent at end-2003, enhancing the prospects for achieving the end-year target despite the recent increase in domestic fuel prices. ${ }^{6}$ Nonfood inflation, which accounts for about 30 percent of the consumer price index, has been declining since the beginning of the year. Food prices continue to benefit from a bountiful harvest and underlying structural improvements in the agricultural sector.
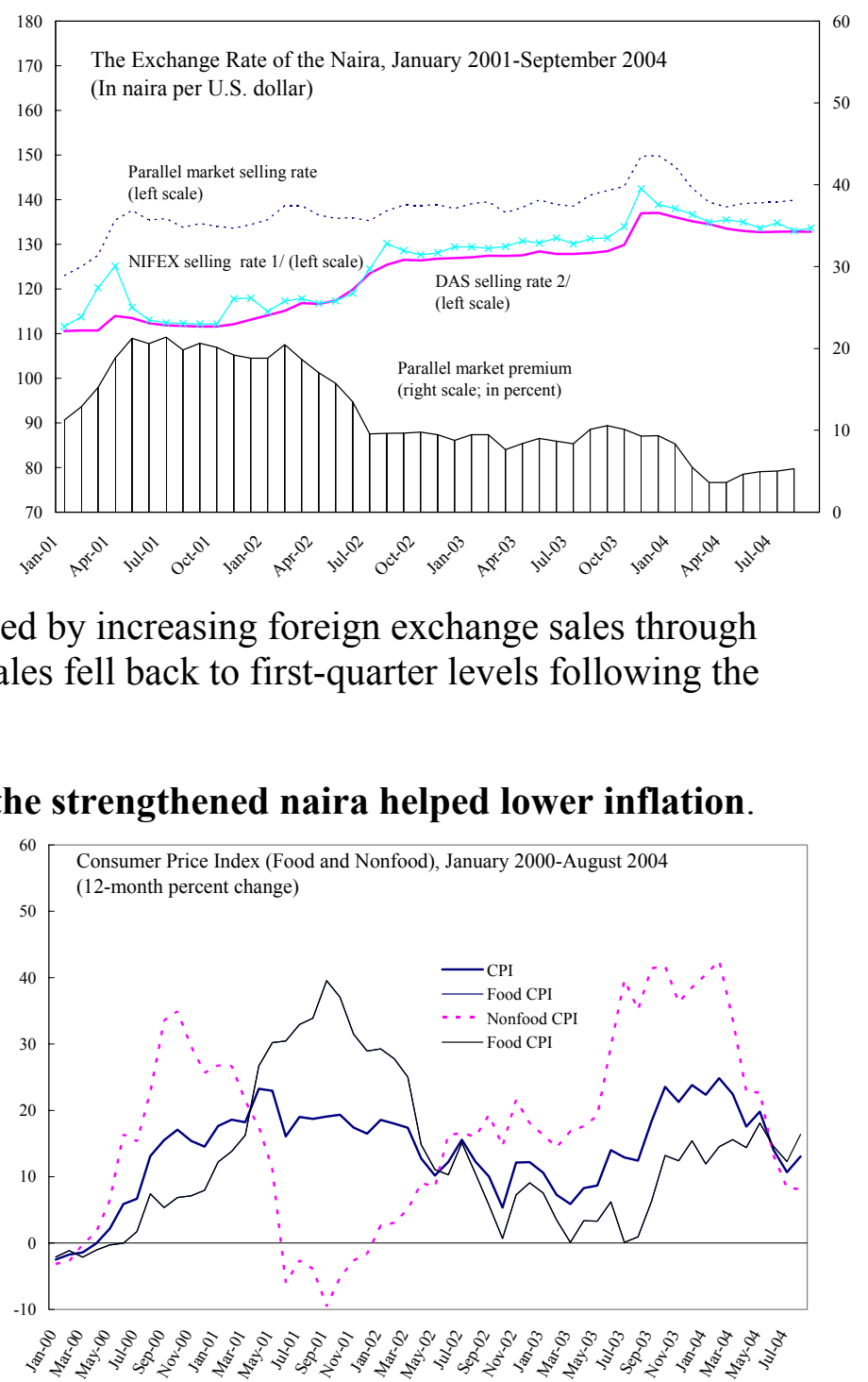

${ }^{6}$ Following rulings of the High Court of Abuja in January and May, pump prices were fixed below import parity cost. The Nigerian National Petroleum Corporation (NNPC) was forced to absorb the cost of the subsidy by drawing on its cash reserves. In mid-September, the court's injunction against fuel price increases was lifted. In response, NNPC adjusted wholesale prices to cover costs of importing refined products, and oil marketing companies increased pump prices by about 25 percent in September in line with higher costs. This adjustment is expected to add about 3 percentage points to the consumer price index. 
8. As a result of record high oil export proceeds and prudent macroeconomic policies, international reserves rose from 3.8 months of imports at end-2003 to 4.9 months of imports at end-June $2004{ }^{7}$ The stronger-thanprogrammed increase in the first half of 2004 was largely due to a more restrained fiscal position. Gross reserves rose further through September.

9. Reflecting prudent macroeconomic management of the positive terms of trade shock, the real exchange rate has remained largely unchanged since end2003.

10. External debt-service payments were made as budgeted. During JanuaryAugust, the authorities continued to meet all obligations falling due to multilateral and commercial creditors. External debt-service payments amounted to US $\$ 1.1$ billion, of which US\$0.7 billion was paid to Paris Club

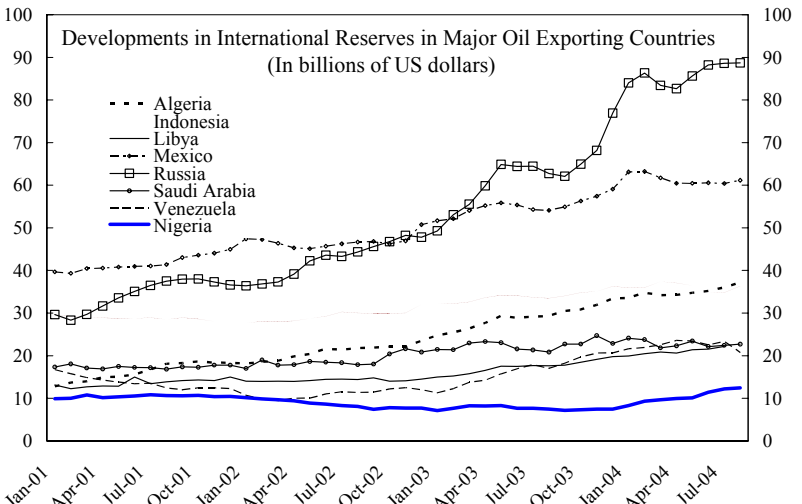

Source: IFS; Central Bank of Nigeria.

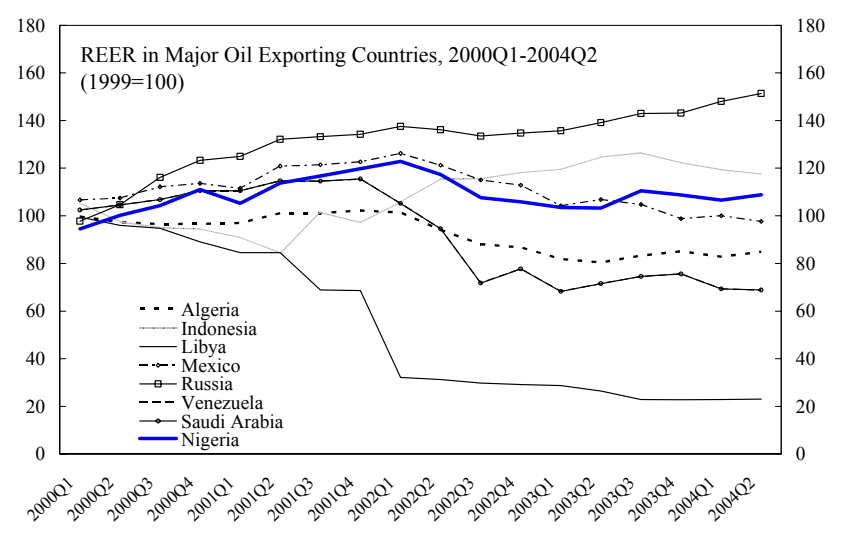

Source: IFS; Central Bank of Nigeria. creditors, consistent with the budget appropriation to pay US\$1.8 billion for the year. ${ }^{8}$ Among the remaining bilateral rescheduling agreements from the 2000 Paris Club agreement, that with Finland was signed in late September.

11. Movements in sovereign risk spread suggest that confidence in the Nigerian economy is gradually returning. Nigeria's spread over the overall JP Morgan Emerging Market Bond Index Global has narrowed by about 50 basis points since end-2003. Investor confidence improved, visible in the commitments of about US\$150 million

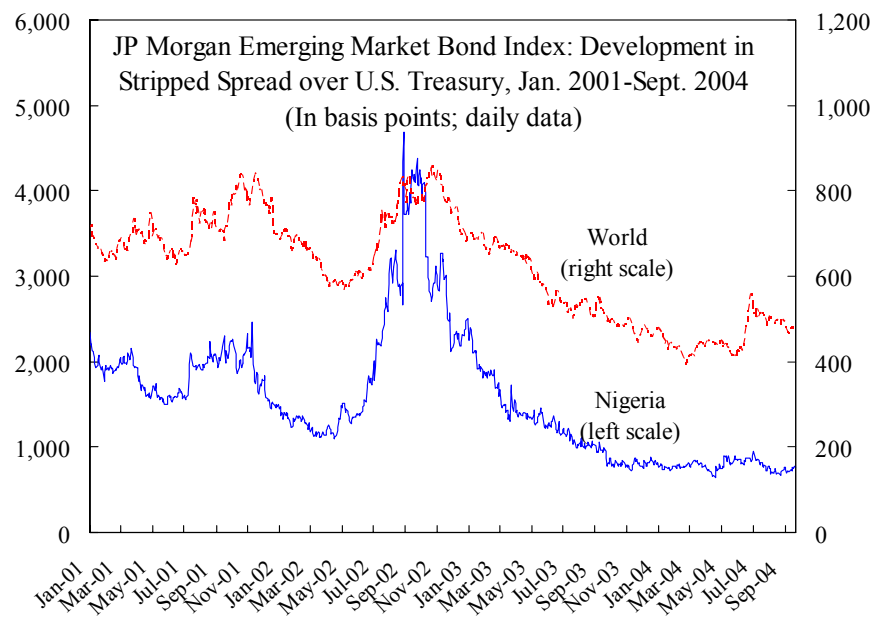

${ }^{7}$ Excluding services, the import coverage ratio was 7.8 months at end-June.

${ }^{8}$ The total amount due to the Paris Club in 2004 is US\$2.2 billion. 
new investment made by several large multinational corporations in the non-oil economy during the first half of 2004.

12. Progress has been made in implementing the structural reform agenda. Several measures have been taken to reform the civil service, public procurement, and the banking system. The Extractive Industries Transparency Initiative (EITI) is also moving forward.

\section{A. Civil Service Reforms}

- The restructuring of five pilot ministries and agencies has advanced. ${ }^{9}$ The first phase scheduled to be completed by the end of the year, entails completing payroll surveys to eliminate ghost workers, assessing skills to identify redundancies and training needs, and streamlining the organizational structure. ${ }^{10}$ The second phase, which focuses on the financing of severance packages and training programs, is scheduled for 2005.

- The Head of Service Office has directed several large ministries (e.g., works, health and education) to examine their payroll, confirm the legality of employees, and assess the skills of their staff. These directives are being issued ahead of the finalization of the pilot programs. The authorities expect that this could eventually result in a sizable reduction in personnel.

\section{B. Customs Administration Reforms}

- A new head of customs administration was appointed, 30 senior officials were removed on findings of corruption, and 80 additional senior officials were retired.

\section{Procurement and Due Process Reforms}

- A consultation workshop was held with the public and private sectors to discuss draft procurement legislation. The final draft law is expected to be submitted to the National Assembly by end-October 2004.

- Due process units have been integrated into all line ministries to review the implementation of their respective capital budgets. The units consist of in-house staff and a sector expert from the Budget Management Price Intelligence Unit (BMPIU). The

\footnotetext{
${ }^{9}$ These include the Ministry of the Federal Capital Territory (MFCT), Ministry of Finance/Budget Office of the Federation (BOF), National Planning Commission (NPC), Ministry of Information, and the State House.

${ }^{10}$ About 3,000 ghost workers and some 250 senior staff positions were eliminated at the MFCT in 2004. The MFCT has begun the skills assessment phase, while BOF is testing an integrated personnel and payroll management system, which will be extended to other ministries and agencies.
} 
BMPIU staff will be doubled to cope with the expanding work assignments, which should help to improve the effectiveness and value for money of the Federal Government's capital budget.

\section{Transparency and Extractive Industries Transparency Initiative (EITI) Reforms}

- An international oil industry expert will be hired shortly to assist the stakeholder monitoring group to draft the terms of reference for the oil revenue payment audits. The auditor is to be selected by January 2005 , with preliminary results expected to be available by mid-2005.

- The authorities published the 2004 half year report on budget implementation, the monthly distribution of oil revenue to all levels of government, and the amounts saved every month.

\section{E. Banking Sector Reforms}

- In July 2004, the CBN announced plans for consolidating the banking sector. Banks will be required to increase their minimum capital base to $\mathrm{N} 25$ billion by end-2005, from $\mathrm{N} 1$ billion at end-2003. ${ }^{11}$ The CBN also announced that it would adopt a zero tolerance policy for misreporting and move toward a risk-based supervision framework-both in line with the recommendations of the 2002 Financial Sector Assessment Program (FSAP). ${ }^{12}$

13. However, progress in other areas has been protracted. ${ }^{13}$ A number of priorities, such as the privatization of the oil refineries, have been delayed. ${ }^{14}$ In addition, a tariff reform,

${ }^{11}$ Banks achieving the new end-2005 target will benefit from a number of incentives, including amnesty on past misreporting, authorization for foreign exchange dealing and access to public funds.

12 The 2002 Financial System Stability Assessment (FSSA) concluded that there were serious concerns about the soundness and stability of the banking system in Nigeria. The system was characterized by (i) weak corporate governance; (ii) widespread insider lending; (iii) high level of non-performining loans and systemic underprovisioning; (iv) dependence on government for business and deposits; (v) persistent misreporting by many banks; and (vi) weak supervisory framework, with a heavy reliance on direct controls. For a more detailed discussion, see IMF Country Report No. 03/3 and No. 04/239.

${ }^{13}$ See Appendix III for progress made in structural reforms.

${ }^{14}$ The delay was due in part to the complexity of the operation, including the need for proper due diligence, and was worsened by a temporary court injunction that froze prices on refined petroleum products. 
which was initially expected to go into effect on July 1, 2004, will now be introduced a year later. ${ }^{15}$ The tariff structure will be streamlined to five tariff bands $(0,5,10,20$ and 50 percent). Duty concessions will no longer be granted. Existing import bans will be phased out in 2007 and replaced by the highest tariff rate.

\section{REPORT ON THE DISCUSSIONS}

14. Discussions focused on the outlook for the remainder of the year and program risks and challenges. Preliminary discussions were also held on the 2005 federal government budget and the implications of the announced banking sector reforms for the vulnerability of the financial system.

15. While good progress was made toward restoring macroeconomic stability in the first half of the year and the outlook for the remainder of 2004 is promising, the challenges and risks remain considerable. The most pressing challenges are to continue to save the oil revenue windfall, consolidate the macroeconomic stability achievements made so far, including preserve fiscal discipline, and deepen the reform process. The Nigerian economy is also vulnerable to social and political risks, visible in the recent labor strikes and unrest in the oil-rich Niger Delta region as well as ethnic conflicts in some northern states. ${ }^{16}$ Furthermore, capacity constraints continue to impede the implementation of the reform agenda, including in monitoring program implementation.

\section{A. Short-term Outlook and Immediate Policy Challenges}

16. The macroeconomic outlook for the remainder of 2004 is good. Higher world oil prices and continued prudent macroeconomic policies are expected to allow for sizable savings of the oil revenue windfall, lower inflation, and larger international reserves.

17. The authorities have revised their macroeconomic framework for 2004 as follows: The average oil price for the year was increased to US\$35.8 per barrel from US $\$ 33.5$ per barrel, while oil production - reflecting capacity constraints - was lowered in the second half of the year from $2.5 \mathrm{mbd}$ to $2.4 \mathrm{mbd}$. The net impact is higher oil export proceeds and lower oil GDP growth for the year. By contrast, the non-oil GDP growth and current account surplus targets for the year remain unchanged. Owing largely to the

${ }^{15}$ The authorities indicated that the delays were primarily due to the realization that additional time was required to build consensus around the reforms.

16 The National Labor Congress called a labor strike in early October 2004 to protest increases in domestic fuel prices. In addition, workers for the oil and gas industry went on a two-day strike to protest restructuring plans by local affiliates of international oil companies. So far, the impact of these strikes on exports and oil production has been limited. The government has announced that it will establish a committee, with civil society participation, to design measures that will mitigate the adverse impact of higher fuel prices on the poor. 
unexpected oil windfall savings from all states in the first half of the year, international reserves were revised up to US\$13.7 billion at end-2004 (6.6 months of imports). While prospects for achieving the end-year inflation target have improved, the outlook is clouded by increases in domestic fuel prices.

18. In spite of lower revenue, the fiscal performance of the federal government is projected to be in line with the authorities' program target. Both oil revenue and non-oil revenue were revised down largely because of lower petroleum profit taxes (PPT) and profit transfers from federal parastatals. ${ }^{17}$ However, 80 percent of the capital budget is expected to be implemented by end-2004. With reduced capital spending more than offsetting lower non-oil revenue, the federal government will register a slightly smaller than programmed non-

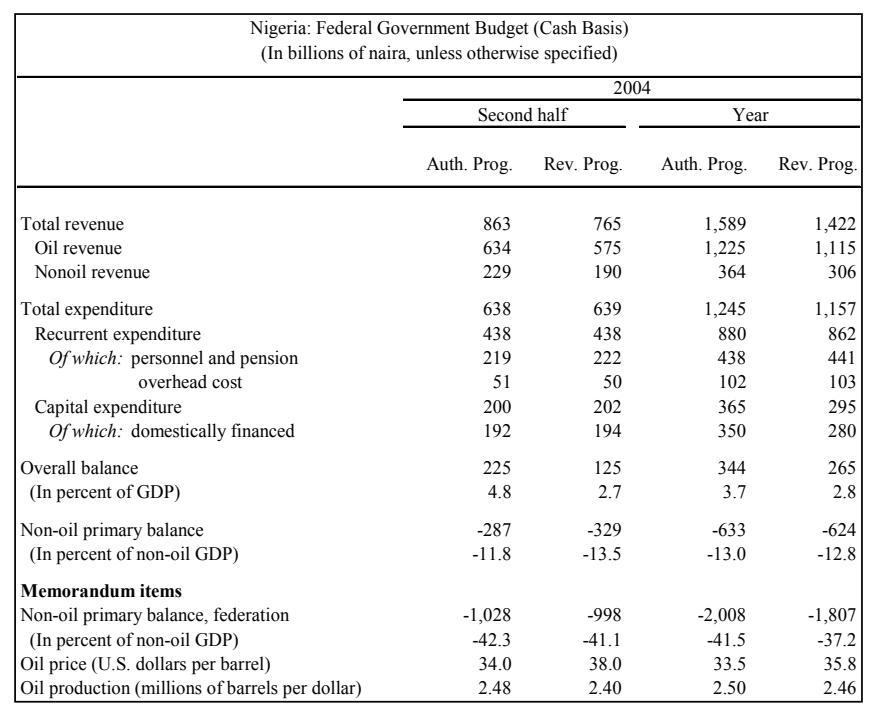
oil primary deficit. However, the overall cash surplus will be smaller than initially projected.

19. Discussions further focused on the feasibility of implementing the capital budget. The authorities indicated that, aside from the late passage of the 2004 budget, poor project conception, planning and costing by line ministries also contributed to the slow implementation. In addition, several agencies postponed project planning because they were not convinced that funds would be forthcoming given their past experience of shortages in capital appropriations. With capital releases more predictable and steady, the authorities expect implementation to improve in the second half of 2004.

20. Staff also inquired about progress made in meeting the objectives of the National Economic Empowerment and Development Strategy (NEEDS). The authorities noted that review of performance in priority line ministries (education, health, power, water, and works) indicated that progress, albeit slower than expected, was achieved: (i) electricity generation and transmission capacity have increased by 7 percent and 12 percent, respectively; (ii) the road maintenance program is on target, with most of the work completed, although road construction projects have progressed more slowly than envisaged. Outcomes in the health sector have been disappointing. End-year targets for immunization and polio eradication are

${ }^{17}$ Estimated tax collection from PPT for the year was lowered. The authorities indicated that they would review the method used for projecting PPT because they may not be accounting for all costs claimed by oil companies against their tax liability. 
not likely to be met. ${ }^{18}$ To achieve most of the goals set out under NEEDS for 2007, the authorities stressed that these programs would have to be accelerated.

21. The consolidated non-oil primary deficit is projected to be larger in 2004 than in 2003. However, the sizable increase in oil revenue will allow for substantial savingsestimated at 9 percent of non-oil GDP for the year. The authorities' program projections assume that the oil revenue windfall savings achieved during the first half of 2004 will not be distributed but that only 12 out of the 36 states will save the oil revenue windfall in the second half of 2004. The authorities are cautiously optimistic that they will be able to persuade all states to save the windfall for the remainder of the year. If all 36 states were to save the windfall in the second half of 2004, this would result in a smaller non-oil primary deficit for 2004 and increase fiscal savings by an additional 2 percent of non-oil GDP.

22. In this context, the authorities reiterated the importance of timely finalization and passage of the Fiscal Responsibility Bill for sound fiscal management in Nigeria. The bill has far-reaching implications for fiscal and macroeconomic management in Nigeria. It would, among others, establish clear rules for budget formulation, execution, reporting and auditing at all levels of government, including applying an oil price-based fiscal rule to manage oil revenue and insulate the economy from sharp movements in oil prices. The authorities emphasized that a number of critical issues are being discussed with the states, such as their desire to have own savings accounts with the CBN. However, they also indicated that for the oil price-based rule to be meaningful, understandings on triggers for use would need to be formalized. Following more than a year of consultation with various key stakeholders, the authorities are hopeful that the bill would be passed by mid-2005.

23. While the CBN's original monetary framework remains consistent with lowering inflation to 10-13 percent by end-2004, staff stressed the need for continued vigilance to curb any emerging demand pressures. The authorities increased the gross international reserve accumulation program target from US\$5 billion to US\$6.2 billion, reflecting the more restrained fiscal stance and higher oil proceeds. The full-year reserve money and broad money targets were left unchanged. Staff pointed out that the inflation outlook for the remainder of the year was uncertain. Liquidity increases and reserve money expansion could come from the 24 states spending their oil revenue windfall from the second half of 2004 and from accelerating the implementation of the federal capital budget. Staff recommended that the $\mathrm{CBN}$ stand ready to actively manage excess liquidity through the use of open market operations, including, if necessary, allowing for higher short-term interest rates in order to smooth liquidity conditions and ensure consistency with the monetary targets. This would also help quell foreign exchange market pressures.

${ }^{18}$ Of the 45.2 million children projected to be immunized by end-2004, only 36 percent were vaccinated by June 2004 . 
24. The CBN officials indicated that, if necessary, to curb inflationary pressures, they would prefer fiscal adjustment and the use of foreign exchange sales, rather than more aggressive open market operations. They also stressed that changes in the exchange rate affect inflation within three months, while changes in interest rates have longer lags. Central Bank officials also felt that political pressure as well as the weak financial situation of banks may prevent them from more actively managing excess liquidity. ${ }^{19}$ While recognizing these institutional and legal constraints on monetary policy, staff noted that interest rates have, for the most part, been fixed and negative in real terms. In addition, it stressed that foreign exchange sales should be consistent with the CBN's monetary program and a market-determined exchange rate. Staff also urged the authorities to continue to examine the transmission channels of monetary policy, in particular the stability and relations between various monetary aggregates and prices; the CBN's monetary framework should be modified in light of this analysis.

\section{B. Fiscal Framework for 2005}

25. Preliminary discussions were held on the 2005 federal government budget. The federal government, in line with 2004 Article IV consultation recommendations, began the 2005 budget cycle earlier than in recent years. The authorities indicated that they plan to increase the capital budget to accommodate the priorities outlined under NEEDS, while limiting the overall cash deficit to 3 percent of GDP at the reference price for crude oil of US\$27 per barrel. The authorities noted that they reached understandings with all state and local governments (SLGs) on the fiscal framework for 2005. They indicated that the oil revenue windfall in excess of the reference price will be saved by all tiers of government. The federal government and the SLGs will use 50 percent of their projected 2004 oil revenue windfall savings to finance higher capital budget and other priority programs in 2005.

26. Staff's preliminary estimates indicate that implementing these understandings would result in a more expansionary fiscal stance in 2005 than in 2004, as indicated by the two percentage points deterioration in the consolidated non-oil primary deficit. ${ }^{20}$

${ }^{19}$ In late July 2004, the CBN began withdrawing some public sector deposits from commercial banks to mop up excess liquidity. This was expected to lead to tighter money market conditions, as banks with large public sector deposits tend to be net placers of these funds in the interbank market. However, as the withdrawal operations occurred at about the same time as the CBN announced its bank consolidation reforms, a number of smaller, weaker banks began experiencing liquidity problems, with the larger banks less willing to place surplus funds with them, resulting in sharp increases in overnight call rates, prompting the central bank to stop its withdrawal of public sector deposits.

${ }^{20}$ Under the current working assumptions with only 12 out of the 36 states saving the oil windfall in the second half of 2004 but all states saving the first half year windfall, the 50 percent use of the savings achieved in 2004 would result in a two percentage point deterioration in the nonoil primary balance as percent of nonoil GDP. If all states save the oil 
However, the fiscal framework would also yield substantial savings of the windfall and an overall budget surplus of 12 percent of GDP at the projected WEO oil price of US\$42.8 per barrel, allowing for a further reduction in net public debt.

27. Staff also discussed ways to improve the effectiveness of the capital budget to meet the objectives of poverty reduction and higher growth established under NEEDS. The draft 2005 budget proposal was submitted to the National Assembly on October 12, 2004 for approval by year-end. In addition, as part of the preparation of the 2005 budget, a medium-term expenditure framework (MTEF) has been prepared. The authorities expect this to help promote more stable public expenditures and improve the capital project planning process for line ministries as well as establish a strong link between the budget and the priorities of government. Furthermore, a special unit within the Ministry of Finance will be established to conduct project return assessments.

\section{Technical Assistance and Capacity Building}

28. The government is making more effective use of technical assistance (TA). A Fiscal Affairs Department (FAD) mission visited Abuja in July 2004 to assess tax administration at the Federal Inland Revenue Service (FIRS), with a particular emphasis on large taxpayers, and more specifically, the oil and gas sector. It proposed a comprehensive tax administration reform strategy centered on a function-based organization with strong headquarters and integrated field offices as well as a full-service Large Taxpayers Office. The mission also recommended a sound governance structure, a tax procedures code, staff restructuring, and extensive IT support. The authorities indicated that they would follow up on the recommendations and seek further TA to improve their audit capabilities of the oil sector.

29. Staff held discussions on the implications of the announced bank consolidation reforms on the vulnerability of the financial system and reviewed the need for further technical assistance in this area. A Monetary and Financial Systems Department (MFD) mission visited Abuja in early August to review the bank consolidation plans. Given balance sheet weaknesses in a number of banks, these reforms could result in market pressures and the failure of some banks. ${ }^{21}$ The mission and the authorities agreed that further TA was required in order to minimize such risks. It is envisaged that MFD will deliver a TA package to strengthen banking supervision - along the recommendations of the 2002 FSSA

revenue windfall in the second half of 2004, the non-oil primary deficit would deteriorate by 4 percentage points of nonoil GDP in 2005.

${ }^{21}$ The Nigerian banking system includes 89 deposit banks with 3,300 branches, with the top ten banks controlling around half of total assets. The CBN assessed that as of end-2003 about 11 banks were insolvent and 24 marginally sound. They account for about 17 percent of the banking system's deposits (21/2 percent of GDP). 
report - and review the legal and regulatory framework, with the aim to help the authorities restructure the banking system in line with best practice principles.

\section{Technical assistance has also been provided by the Fund to review reforms} aimed at exchange rate unification and CBN's monetary policy framework. The mission supported the authorities' intention to move to a wholesale DAS, as this would help unify the current retail DAS with the Nigerian interbank foreign exchange market, and recommended that prudential regulations for open positions be strengthened and banks be required to report on a daily basis. The mission also reviewed the CBN's liquidity management framework, and recommended that the $\mathrm{CBN}$ : (i) clarify and reinforce its commitment to price stability as a primary objective of monetary policy; (ii) establish a liquidity forecasting unit; (iii) actively manage day-to-day liquidity consistent with the daily targets and the reserve money program; and (iv) and strengthen liquidity management by gradually withdrawing from the treasury bill market, phasing out government borrowing from the CBN, and relying on short-term instruments. It is expected that further TA would be provided to set up an appropriate liquidity forecasting framework and to operationalize the wholesale DAS.

\section{Staff reiterated the importance of timely and accurate provision of key data.}

While it recognized progress made in policy coordination and overall data gathering, staff stressed the need for improving data collection and reconciliation. In particular, it recommended that the technical committee for data collection established earlier in 2004 be made operational as a matter of urgency, and be given a dedicated staff and develop monthly output tables, consistent with the requirements for monitoring the authorities'

macroeconomic program on a quarterly basis. Staff also recommended that the monthly reports of the federal government include movements in government accounts with the CBN and commercial banks and that the classification of federal government deposits at the CBN be made consistent with the federal government definition, as presented by the BOF. In this context, the authorities indicated that they would move to a Treasury Single Account for the federal government in 2005, hoping this will improve transparency of fiscal accounting and cash management. Finally, staff urged the CBN to improve the quality of data collection and reconciliation, urging it to review the implementation of its monetary program at a higher frequency, preferably on a weekly basis, and improve its communication with the public through frequent reporting on performance and policies.

\section{STAFF APPRAISAL}

32. Overall economic performance in the first half of 2004 was commendable. The implementation of prudent macroeconomic policies, underpinned by a conservative reference oil price and savings of the windfall oil revenue, has helped stabilize the economy. This along with a tight monetary policy has contributed to a build up of international reserves, a sharp decline in inflation, and exchange rate stability. These developments signal a reversal of past imprudent macroeconomic policies and will help reduce Nigeria's vulnerability to oil price shocks. They also offer hope that implementation of the reform agenda will lead to a durable transformation in economic management that will, in turn, help realize Nigeria's vast growth potential and bring about a rapid improvement in living standards. 
33. The immediate challenge facing the government is to consolidate these achievements and convince all states to continue to save the windfall oil revenue. It will be essential to preserve and reinforce fiscal discipline and solidify the gains made in macroeconomic stabilization. Early passage of the Fiscal Responsibility Bill will help provide the legal underpinning for a prudent consolidated fiscal policy, including a framework for policy coordination, consistent budget formulation and reporting, and implementation of an oil price-based rule at all levels of government.

34. The CBN should continue with the implementation of a credible monetary framework aimed at achieving the end-year inflation target. Given the uncertain inflation outlook, the CBN needs to stand ready to actively manage excess liquidity consistent with its monetary targets through open market operations rather than foreign exchange sales. For these to be effective, interest rates need to adjust to underlying demand and supply conditions in the money market. Staff further encourages strengthening liquidity management practices as these would enhance the operational effectiveness of monetary policy. In this context, staff reiterates the need for early exchange rate unification and encourages reforms that will transform the current retail auction to a wholesale auction system. However, for these reforms to have the intended impact, it will be important that the CBN's legal and operational independence be strengthened and weaknesses in the banking system addressed.

35. Staff welcomes progress made in the restructuring of the pilot ministries and agencies. It encourages the authorities to complete the first phase of the reforms by end-2004 and progress to the second phase of retrenchment and training in 2005. Experience gained here could be useful for the restructuring of all other line ministries.

36. Staff commends Nigeria's efforts to improve transparency and accountability of public finances, in particular with regard to the oil sector. The planned audits of the oil sector and the early passage of the procurement reform bill should help strengthen transparency of oil revenue and public expenditure management.

37. The privatization program needs to be invigorated. Deregulation and privatization, particularly in the telecommunications, transportation, power generating and downstream petroleum sectors, should be accelerated to address the problem of chronic shortages and bottlenecks and to attract new investment. The country's poor and unreliable infrastructure is a major deterrent to higher growth of the non-oil economy. Staff is concerned that the authorities have not been able to move as fast as intended on trade reforms, which are to streamline the tariff regime consistent with ECOWAS's regime, and urges the authorities to implement them without any further delay. It also calls for an early replacement of all quantitative restrictions on imports with tariffs. Trade liberalization in the context of sound macroeconomic policies and improved infrastructure will be vital to spur export-oriented growth.

38. While staff welcomes the announced intention to consolidate the banking system, it urges the CBN to develop a comprehensive strategy that identifies and addresses in a transparent manner the downside risks associated with such a proposed reform. Given 
the importance of the reforms to putting Nigeria's financial system on a solid and sound foundation, staff welcomes the CBN's request for a comprehensive TA package, including reviewing the current framework for supervision, to ensure that the reforms are consistent with best practices.

39. Staff calls on the government to ensure that the $\mathbf{2 0 0 5}$ federal budget remains consistent with fiscal prudence and disinflation objectives. Fiscal prudence is all the more necessary given the planned banking reforms and steps to unify the foreign exchange market. Staff also urges the authorities to enhance the performance of the capital budget, particularly education, health, power, roads, and water. This is essential for improving economic and social conditions in Nigeria, raising the growth prospects of the non-oil economy and shoring up support for the reform program. While noting the need to increase spending to alleviate poverty and move towards meeting the Millennium Development Goals (MDGs), it will be important to ensure that fiscal policy remains sustainable over the medium-term.

40. The weakness of the statistical system for policy formulation and analysis needs to be addressed as a matter of priority. The technical committee for data collection should be made operational and be given a dedicated staff to ensure consistency of data submission for the quarterly implementation of the program. 
Figure 1. Nigeria: Real Sector Developments, 1997-2004
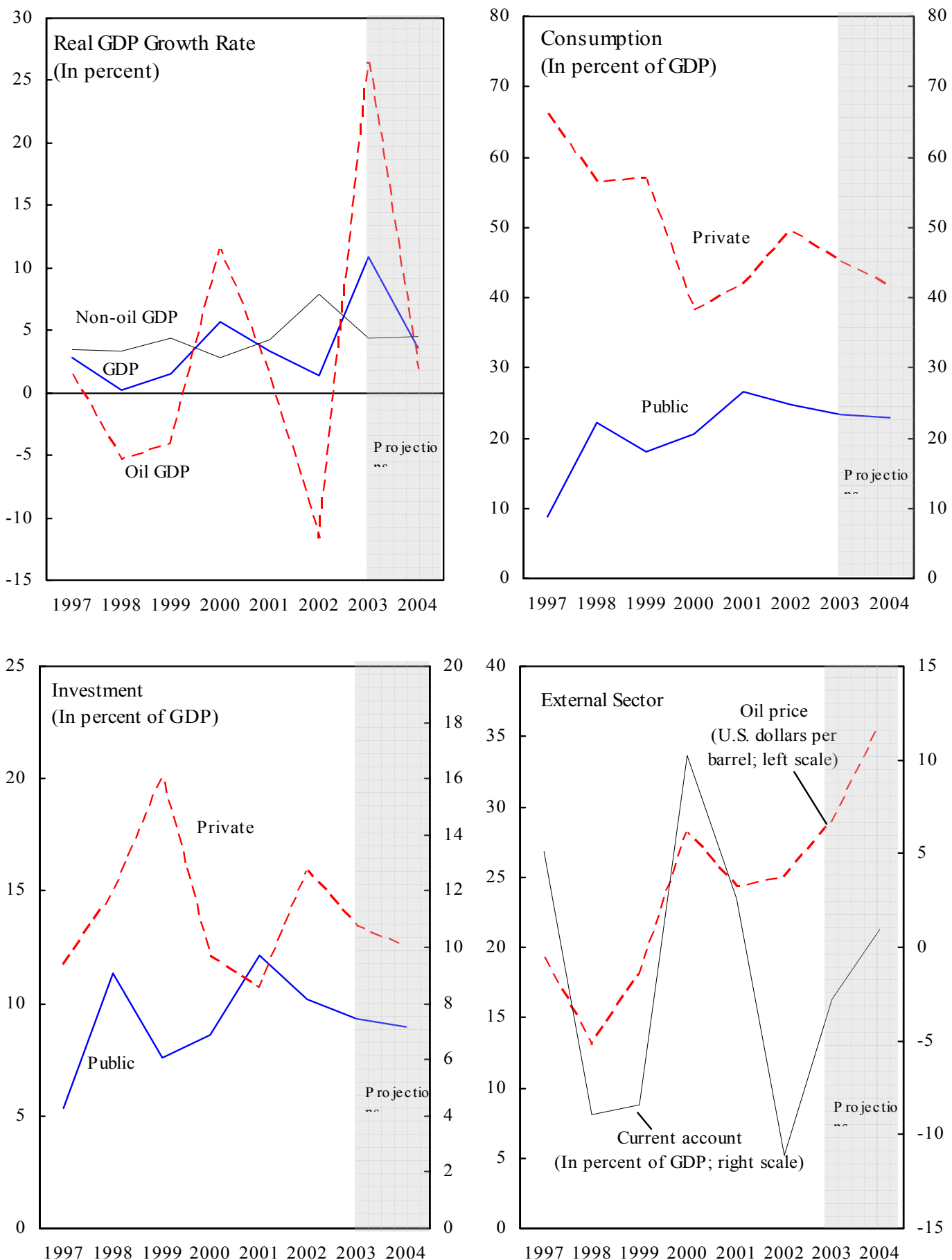

Sources: Nigerian authorities; and Fund staff estimates and projections. 


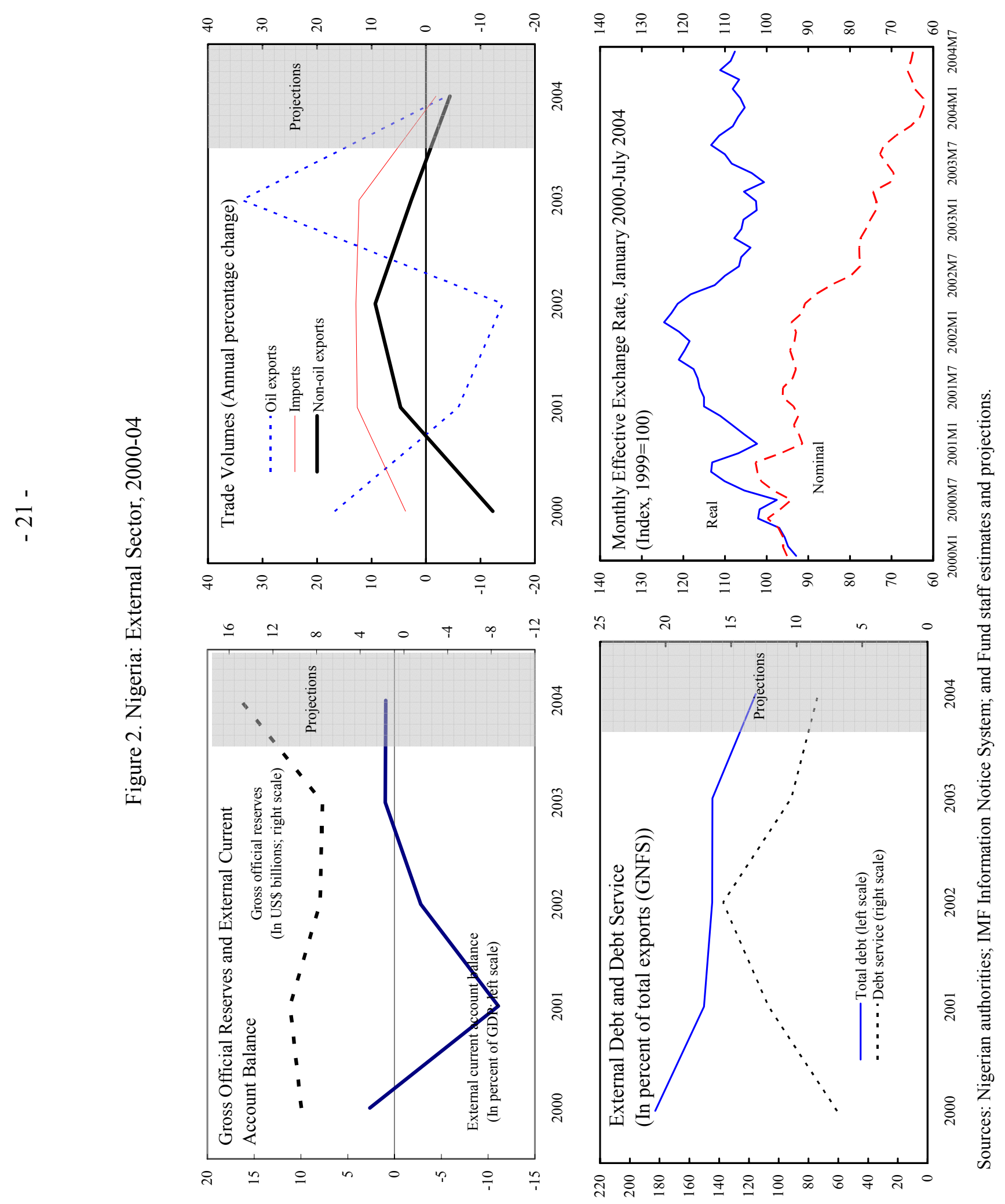


Figure 3. Nigeria: Consolidated Government Operations, 2000-04 (In percent of GDP)

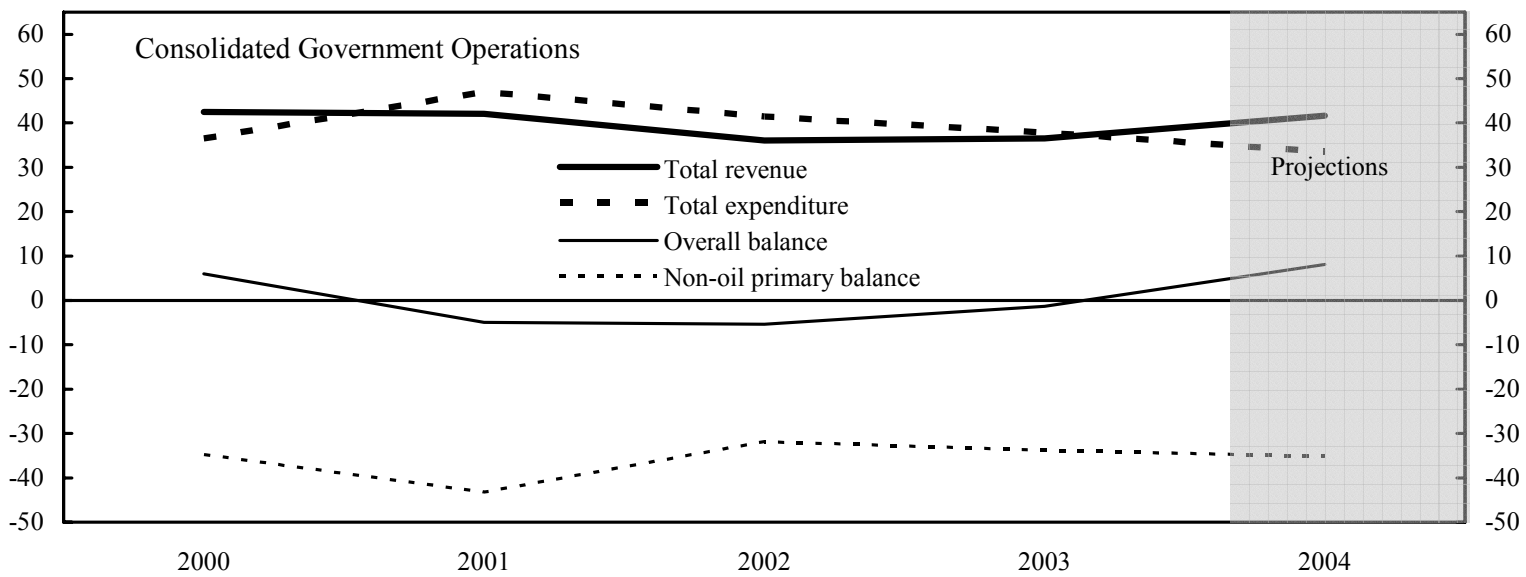

1/ Non-oil primary balance in percentage of non-oil GDP.
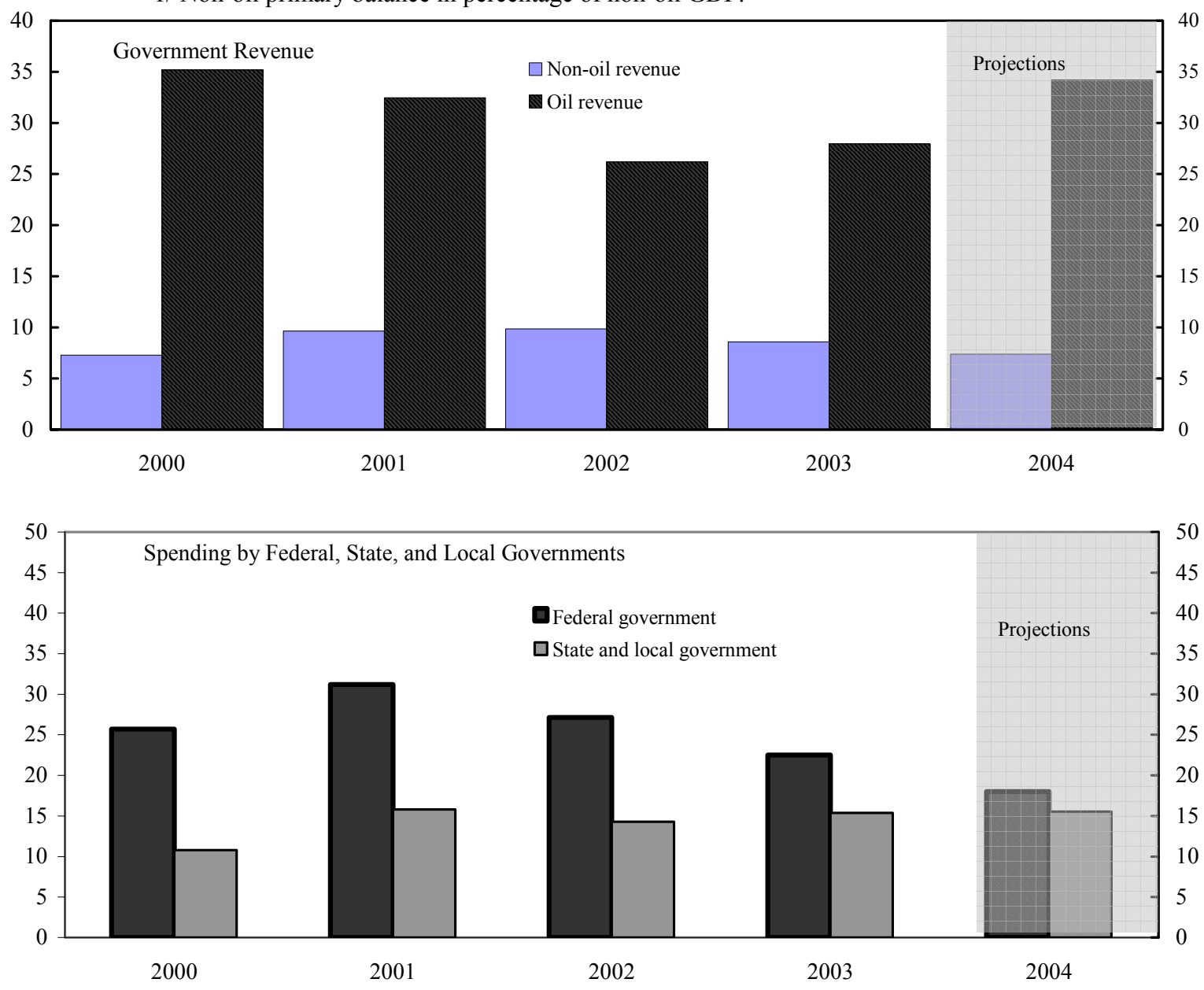

Sources: Nigerian authorities; and Fund staff estimates and projections. 
Figure 4. Nigeria: Monetary Indicators, January 2000-August 2004 (In percent, unless otherwise indicated)
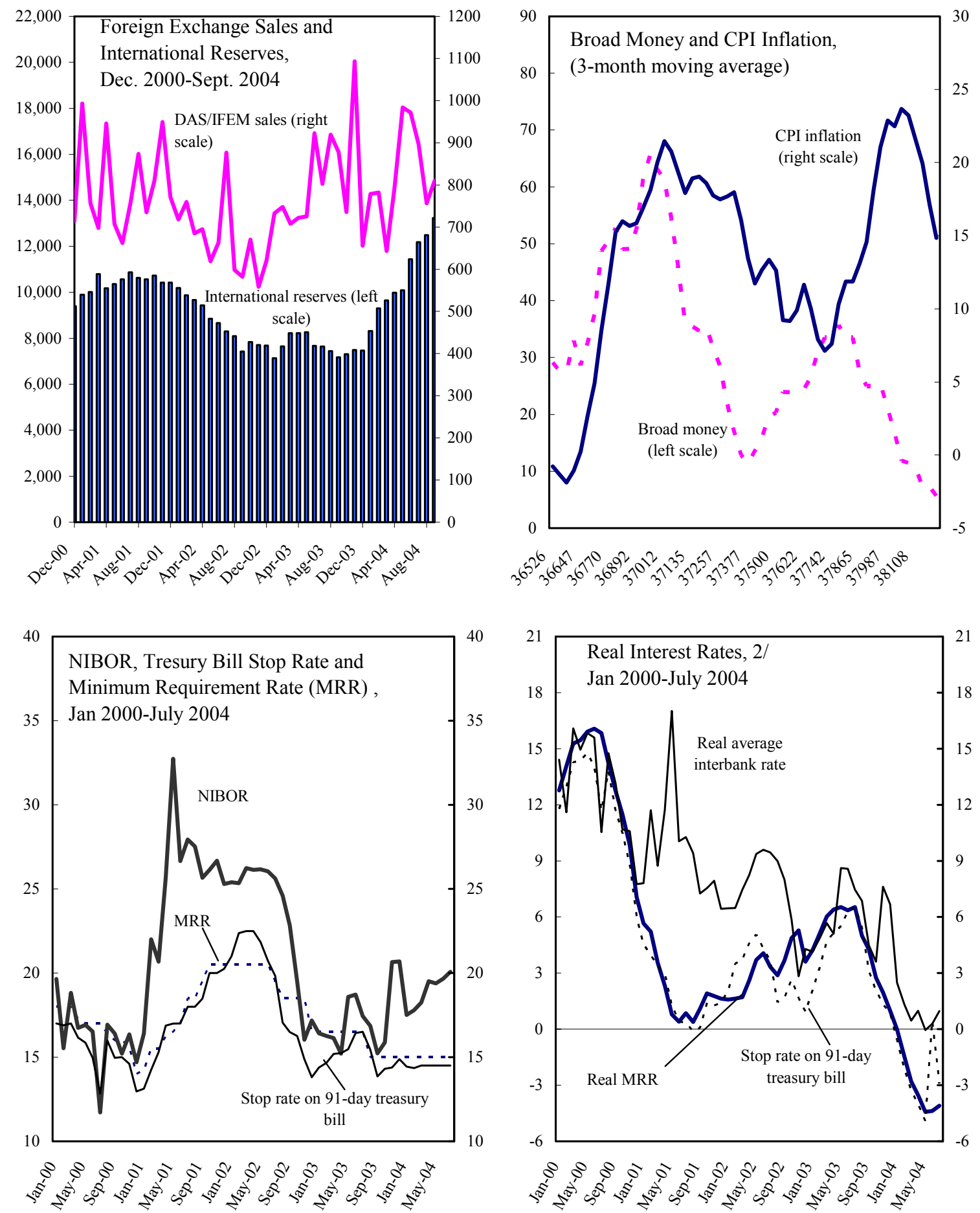

Source: Nigerian authorities, and Fund staff estimates.

1/ The interbank interest rate is a weighted average of the 7-day call rate (49 percent weight) and the 30- and 90 . day rates (20 percent weight each).

2/ Adjusted for annual average consumer price index inflation. 
Table 1. Nigeria: Selected Economic and Financial Indicators, 2001-05

\begin{tabular}{|c|c|c|c|c|c|c|}
\hline & \multirow[t]{2}{*}{2001} & \multirow[t]{2}{*}{2002} & \multicolumn{3}{|l|}{2003} & \multirow{2}{*}{$\begin{array}{c}2005 \\
\text { Proj }\end{array}$} \\
\hline & & & Est. & CR 04/239 & Proj. & \\
\hline & & nnual per & age chan & ges, unless oth & wise spec & ified) \\
\hline National income and prices & 3.3 & 1.4 & & & 3.6 & \\
\hline Oil GDP & 1.4 & $\begin{array}{r}1.4 \\
-11.6\end{array}$ & $\begin{array}{l}10.9 \\
26.5\end{array}$ & $\begin{array}{l}4.1 \\
3.3\end{array}$ & $\begin{array}{l}3.6 \\
1.9\end{array}$ & $\begin{array}{r}7.5 \\
12.9\end{array}$ \\
\hline Non-oil GDP & 4.3 & 8.0 & 4.4 & 4.5 & 4.5 & 4.9 \\
\hline Agriculture & 3.9 & 4.3 & 6.5 & 4.3 & 4.3 & 4.7 \\
\hline $\begin{array}{l}\text { Industry } \\
\text { Ind }\end{array}$ & 8.7 & 8.9 & 6.4 & 6.0 & 6.0 & 7.0 \\
\hline Services & 3.6 & 13.0 & 1.2 & 4.2 & 4.2 & 4.5 \\
\hline Real GDP per capita & 0.6 & -1.3 & 7.9 & 1.3 & 0.8 & 4.6 \\
\hline GDP per capita (in U.S. dollars) & 362 & 341 & 415 & 471 & 485 & 582 \\
\hline Non-oil GDP per capita (in U.S. dollars) & 199 & 180 & 201 & 204 & 204 & 224 \\
\hline GDP deflator (period average) & 10.8 & 3.9 & 20.8 & 17.7 & 19.4 & 17.0 \\
\hline Non-oil GDP deflator (period average) & 20.5 & 5.5 & 15.8 & 15.6 & 14.3 & 10.8 \\
\hline Consumer price index (annual average) & 18.0 & 13.7 & 14.0 & 16.5 & 15.1 & 11.5 \\
\hline Consumer price index (end of period) & 16.5 & 12.2 & 23.8 & 11.5 & 10.1 & 9.1 \\
\hline \multicolumn{7}{|l|}{ External sector } \\
\hline Exports, f.o.b. 1/ & -17.5 & -9.8 & 54.6 & 14.7 & 21.1 & 32.7 \\
\hline Imports, fo.b. & 8.8 & 16.2 & 26.5 & 3.4 & 4.5 & 32.9 \\
\hline Non-oil export volume & 4.7 & 9.3 & 2.7 & 9.5 & -4.4 & 11.3 \\
\hline Oil export volume $1 /$ & -6.0 & -14.1 & 33.7 & -2.3 & -3.9 & 11.0 \\
\hline Volume of import of goods and nonfactor services & 10.3 & 11.9 & 10.8 & -3.3 & -1.2 & 25.1 \\
\hline Terms of trade & -10.4 & -0.5 & 2.5 & 7.2 & 15.3 & 18.5 \\
\hline Nominal effective exchange rate (end of period; - indicates depreciation) 2/ & -3.3 & -18.3 & -17.0 & 2.6 & $\ldots$ & $\ldots$ \\
\hline Real effective exchange rate (end of period; - indicates depreciation) $2 /$ & 11.2 & -10.4 & 0.8 & 0.7 & $\ldots$ & $\ldots$ \\
\hline \multicolumn{7}{|l|}{ Consolidated government operations 3 / } \\
\hline Total revenue and grants & 13.1 & -9.7 & 35.5 & 50.4 & 38.2 & 37.7 \\
\hline Oil revenue & 5.3 & -14.8 & 42.7 & 58.7 & 46.8 & 43.0 \\
\hline Capital expenditure and net lending $4 /$ & 61.2 & -11.6 & 23.0 & 34.5 & 18.9 & 26.0 \\
\hline \multicolumn{7}{|l|}{ Money and credit } \\
\hline Net foreign assets $5 /$ & 15.3 & -3.5 & 5.5 & 28.8 & 37.6 & 55.6 \\
\hline Net domestic assets $5 /$ & 12.6 & 25.0 & 19.0 & -21.4 & -23.2 & -41.6 \\
\hline Net domestic credit $5 /$ & 34.6 & 48.3 & 27.2 & -21.4 & -20.6 & -41.6 \\
\hline Net credit to consolidated government & 11.4 & 37.6 & 11.4 & -32.4 & -33.5 & -54.9 \\
\hline Net credit to the federal government & 9.5 & 38.5 & 11.2 & -31.8 & -27.8 & -61.1 \\
\hline Credit to the rest of the economy & 23.0 & 10.8 & 15.7 & 13.8 & 12.9 & 13.2 \\
\hline Broad money & 27.2 & 21.6 & 24.1 & 16.0 & 16.0 & 14.0 \\
\hline Velocity (non-oil GDP as a multiple of end-of-period broad money) & 2.2 & 2.1 & 2.0 & 2.1 & 2.1 & 2.1 \\
\hline Treasury bill rate (percent; end of period) & 20.0 & 14.9 & 17.3 & $\ldots$ & $\ldots$ & $\ldots$ \\
\hline \multirow[t]{2}{*}{ Discount rate (percent; end of period) } & 20.5 & 18.5 & 15.0 & $\ldots$ & $\ldots$ & $\ldots$ \\
\hline & \multicolumn{6}{|c|}{ (In percent of GDP; unless otherwise specified) } \\
\hline Investment and saving & & & & & & \\
\hline Investment & 22.8 & 26.1 & 22.8 & 21.8 & 21.5 & 21.6 \\
\hline Public fixed investment & 12.1 & 10.2 & 9.3 & 10.3 & 9.0 & 9.0 \\
\hline Private fixed investment & 10.7 & 15.9 & 13.4 & 11.6 & 12.5 & 12.6 \\
\hline Gross national savings & 25.4 & 15.0 & 20.0 & 22.8 & 22.4 & 26.8 \\
\hline Public & 15.6 & 11.3 & 13.2 & 19.9 & 18.0 & 24.3 \\
\hline Private & 9.8 & 3.6 & 6.7 & 2.9 & 4.4 & 2.4 \\
\hline Consolidated government operations $3 /$ & & & & & & \\
\hline Total revenues and grants & 42.1 & 36.1 & 36.5 & 44.8 & 40.9 & 44.8 \\
\hline Of which oil and gas revenue & 32.5 & 26.2 & 28.0 & 36.2 & 33.2 & 37.8 \\
\hline Total expenditure and net lending (commitment basis) & 47.0 & 41.4 & 37.9 & 39.5 & 35.9 & 33.5 \\
\hline Overall balance (commitment basis) & -4.9 & -5.4 & -1.3 & 5.3 & 5.0 & 11.4 \\
\hline Non-oil primary balance (in percent of non-oil GDP, commitment basis) & -43.2 & -31.9 & -33.8 & -40.9 & -37.2 & -37.5 \\
\hline Gross domestic debt & 19.0 & 20.7 & 17.7 & 15.1 & 15.0 & 11.9 \\
\hline External sector & & & & & & \\
\hline Current account balance & 2.6 & -11.1 & -2.8 & 1.0 & 0.9 & 5.2 \\
\hline External debt outstanding (in billions of U.S. dollars) & 29.7 & 31.0 & 32.8 & 32.7 & 32.7 & 32.5 \\
\hline External debt service due after rescheduling, $2000-01$ & & & & & & \\
\hline (in percent of exports of goods and nonfactor services) & 5.2 & 6.4 & 5.2 & 4.7 & 4.5 & 3.8 \\
\hline & & n millions & J.S. dolla & ars, unless oth & wise spec & fied) \\
\hline Current account balance & 1,255 & $-5,115$ & $-1,611$ & 681 & 654 & 4,410 \\
\hline Overall balance of payments & -98 & $-4,503$ & $-1,606$ & 3,062 & 4,328 & 7,386 \\
\hline Gross international reserves (end of period) & 10,423 & 7,681 & 7,468 & 12,474 & 13,672 & 22,494 \\
\hline (equivalent months of imports, c.i.f.) & 7.6 & 4.9 & 3.8 & 6.1 & 6.6 & 8.6 \\
\hline Price of Nigerian oil (U.S. dollars per barrel) & 24.3 & 25.0 & 28.9 & 33.5 & 35.8 & 42.8 \\
\hline Production of crude oil (million barrels per day) & 2.26 & 1.96 & 2.45 & 2.50 & 2.46 & 2.71 \\
\hline Including oil and gas equivalent & & 2.15 & 2.72 & 2.81 & 2.77 & 3.12 \\
\hline Interbank Foreign Exchange Market/DAS exchange rate (naira per U.S. dollar; average) & 112.0 & 122.2 & 130.9 & $\ldots$ & $\ldots$ & J.1. \\
\hline Nominal GDP at market prices (in billions of naira) 6/ & 5,339 & 5,632 & 7,533 & 9,235 & 9,309 & 11,685 \\
\hline
\end{tabular}

Sources: Nigerian authorities; and Fund staff estimates and projections.

1/ Export volumes fall more than total production because of an increase in the domestic allocation of crude oil to the Nigerian Naional Petroleum Corporation 2/2004 data are based on end-July 2004 over end-2003.

$3 /$ Consists of the federal, state, and local governments.

4/ Assumes that two-thirds of state and local government expenditure is recurrent expenditure.

$5 /$ In percent of broad money at the beginning of the period.

6/ The GDP series was updated in 2003 and incorporates changes by the authorities to take account of developments in real activity and structural ehanges 
Table 2a. Nigeria: Fiscal Operations (Cash Basis), 2002-05

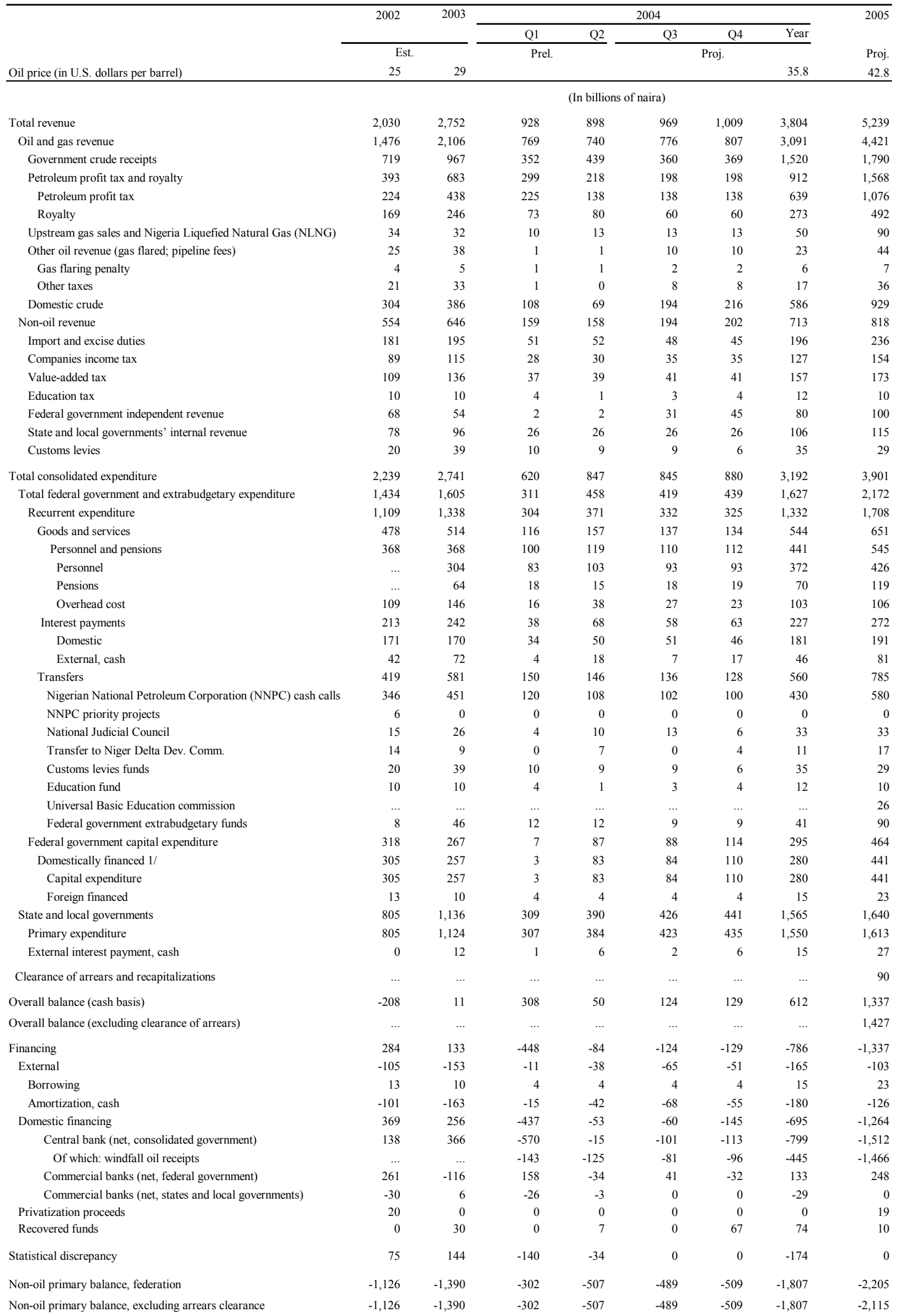


$-26-$

Table 2a. Nigeria: Fiscal Operations (Cash Basis), 2002-05

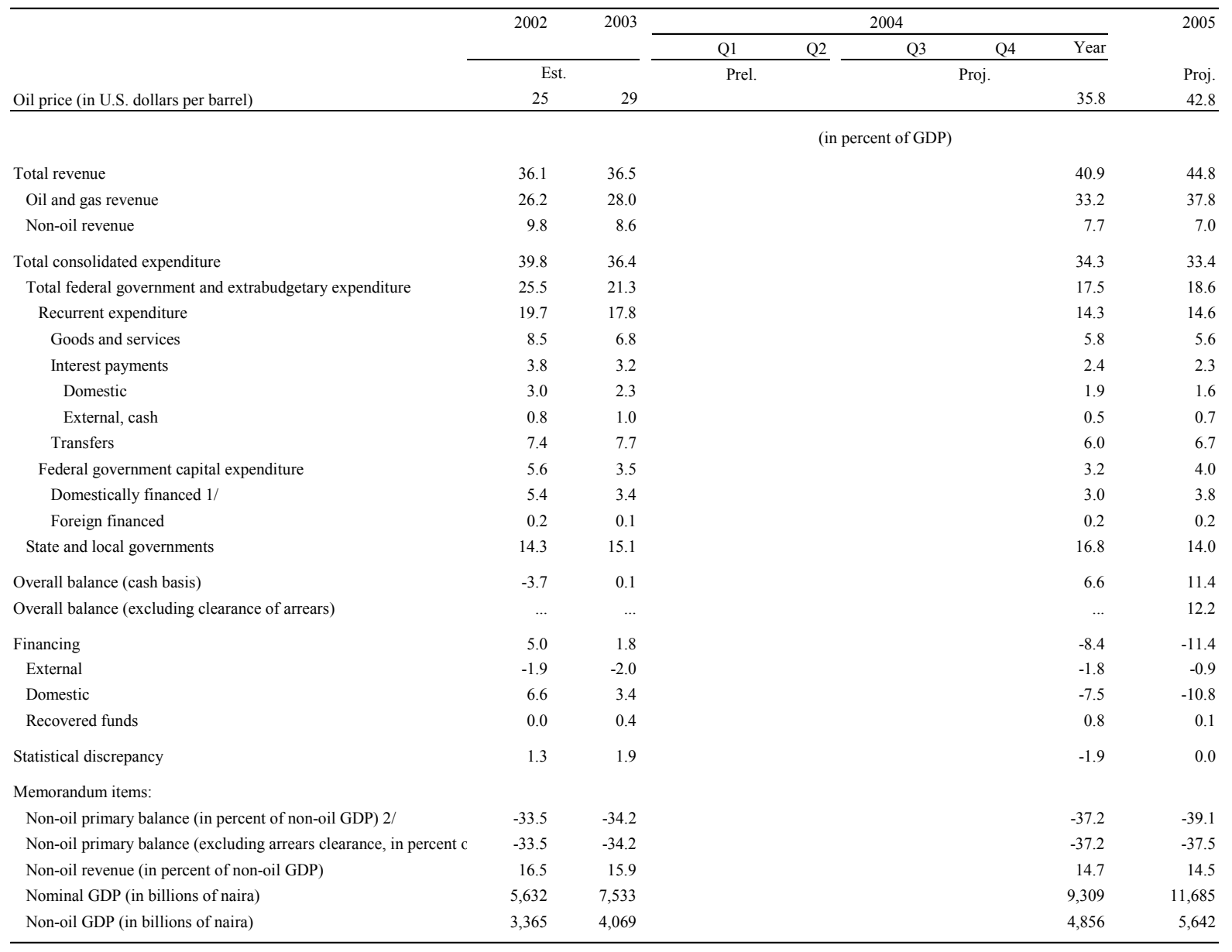

Sources: Nigerian authorities; and Fund staff estimates and projections.

1/ Actual cash spending

2/ Excluding oil revenue, cash call payments, and cash interest payments. 
Table 2b. Nigeria: Fiscal Operations (Commitment Basis), 2001-05

\begin{tabular}{|c|c|c|c|c|c|}
\hline & \multirow[t]{2}{*}{2001} & \multirow[t]{2}{*}{2002} & 2003 & 2004 & 2005 \\
\hline & & & Est. & \multicolumn{2}{|c|}{ Proj. } \\
\hline & & \multicolumn{4}{|c|}{ (In billions of naira) } \\
\hline Total revenue & 2,248 & 2,030 & 2,752 & 3,804 & 5,239 \\
\hline Oil and gas revenue & 1,733 & 1,476 & 2,106 & 3,091 & 4,421 \\
\hline Government crude receipts & 955 & 719 & 967 & 1,520 & 1,790 \\
\hline Petroleum profit tax and royalty & 613 & 393 & 683 & 912 & 1,568 \\
\hline Upstream gas and NLNG & 27 & 34 & 32 & 50 & 90 \\
\hline Other oil revenue & 5 & 25 & 38 & 23 & 44 \\
\hline Domestic crude & 134 & 304 & 386 & 586 & 929 \\
\hline Non-oil revenue & 515 & 554 & 646 & 713 & 818 \\
\hline Tax revenue & 470 & 486 & 592 & 633 & 718 \\
\hline Taxes on international trade and transactions & 195 & 201 & 235 & 231 & 265 \\
\hline Import duties and excises & 171 & 181 & 195 & 196 & 236 \\
\hline Customs levies & 24 & 20 & 39 & 35 & 29 \\
\hline Taxes on net income, profits, and capital gains & 154 & 176 & 221 & 245 & 280 \\
\hline Company income tax & 69 & 89 & 115 & 127 & 154 \\
\hline Education tax & 16 & 10 & 10 & 12 & 10 \\
\hline State and local governments' internal revenue 1 / & 69 & 78 & 96 & 106 & 115 \\
\hline Domestic taxes on goods and services & 122 & 109 & 136 & 157 & 173 \\
\hline Value-added tax (VAT) & 92 & 109 & 136 & 157 & 173 \\
\hline Petroleum tax & 30 & 0 & 0 & 0 & 0 \\
\hline Nontax revenue & 44 & 68 & 54 & 80 & 100 \\
\hline Federal government independent revenue & 44 & 68 & 54 & 80 & 100 \\
\hline Total consolidated expenditure & 2,510 & 2,333 & 2,853 & 3,338 & 3,909 \\
\hline Total federal expenditure & 1,666 & 1,529 & 1,696 & 1,736 & 2,245 \\
\hline Federal government recurrent expenditure & 1,225 & 1,257 & 1,444 & 1,441 & 1,781 \\
\hline Goods and services & 403 & 478 & 514 & 544 & 651 \\
\hline Personnel cost & 285 & 368 & 368 & 441 & 545 \\
\hline Overhead cost & 118 & 109 & 146 & 103 & 106 \\
\hline Interest payments due & 327 & 361 & 349 & 336 & 345 \\
\hline Domestic & 155 & 171 & 170 & 181 & 191 \\
\hline Foreign & 172 & 190 & 179 & 155 & 154 \\
\hline Transfers & 495 & 419 & 581 & 560 & 785 \\
\hline Nigerian National Petroleum Corporation (NNPC) cash calls & 392 & 346 & 451 & 430 & 580 \\
\hline NNPC priority projects & 38 & 6 & 0 & 0 & 0 \\
\hline National Judicial Council & 15 & 15 & 26 & 33 & 33 \\
\hline Transfer to Niger Delta Dev. Comm & 10 & 14 & 9 & 11 & 17 \\
\hline Customs levies funds & 24 & 20 & 39 & 35 & 29 \\
\hline Education fund & 16 & 10 & 10 & 12 & 10 \\
\hline Universal Basic Education commission & $\ldots$ & $\ldots$ & $\ldots$ & $\ldots$ & 26 \\
\hline Federal government extrabudgetary funds & $\ldots$ & 8 & 46 & 41 & 90 \\
\hline Federal government capital expenditure & 441 & 264 & 252 & 295 & 464 \\
\hline Domestically financed & 433 & 251 & 242 & 280 & 441 \\
\hline Foreign financed & 8 & 13 & 10 & 15 & 23 \\
\hline State and local governments & 844 & 805 & 1,157 & 1,602 & 1,664 \\
\hline Primary expenditure & 844 & 805 & 1,124 & 1,550 & 1,613 \\
\hline External interest payments due & $\ldots$ & $\ldots$ & 33 & 52 & 51 \\
\hline Overall balance (commitment basis) 2/ & -262 & -303 & -101 & 466 & 1,330 \\
\hline Financing & 285 & 378 & 245 & -640 & $-1,330$ \\
\hline External & -59 & 43 & -26 & -19 & -5 \\
\hline Borrowing & 8 & 13 & 10 & 15 & 23 \\
\hline Amortization due & -192 & -168 & -179 & -213 & -238 \\
\hline Federal government & $\ldots$ & $\ldots$ & -151 & -160 & -179 \\
\hline States & $\ldots$ & $\ldots$ & -28 & -53 & -60 \\
\hline Arrears, rescheduling, and debt buyback & 125 & 197 & 143 & 179 & 210 \\
\hline Domestic & 137 & 369 & 256 & -695 & $-1,344$ \\
\hline Net claims on federal government & 99 & 399 & 250 & -386 & $\ldots$ \\
\hline Central bank & 164 & 138 & 366 & -518 & $\ldots$ \\
\hline Banking system & -65 & 261 & -116 & 133 & $\ldots$ \\
\hline Net claims on state and local governments & 38 & -30 & 6 & -310 & $\ldots$ \\
\hline Privatization proceeds & 86 & 20 & 0 & 0 & 19 \\
\hline Recovered funds & 0 & 0 & 30 & 74 & 0 \\
\hline Carryover of unspent capital mandates 3 / & 121 & -54 & -16 & 0 & 0 \\
\hline Statistical discrepancy & 23 & 75 & 144 & -174 & 0 \\
\hline \multicolumn{6}{|l|}{ Memorandum item: } \\
\hline Non-oil balance & $-1,604$ & $-1,433$ & $-1,756$ & $-2,195$ & $-2,511$ \\
\hline Non-oil primary balance 4/ & $-1,277$ & $-1,072$ & $-1,375$ & $-1,807$ & $-2,115$ \\
\hline Primary balance & 65 & 58 & 248 & 854 & 1,726 \\
\hline
\end{tabular}


Table 2b. Nigeria: Fiscal Operations (Commitment Basis), 2001-05

\begin{tabular}{|c|c|c|c|c|c|}
\hline & 2001 & 2002 & 2003 & 2004 & 2005 \\
\hline & & & Est. & \multicolumn{2}{|c|}{ Proj. } \\
\hline & & \multicolumn{4}{|c|}{ (In percent of GDP; unless otherwise indicated) } \\
\hline Total revenue & 42.1 & 36.1 & 36.5 & 40.9 & 44.8 \\
\hline Petroleum revenue & 32.5 & 26.2 & 28.0 & 33.2 & 37.8 \\
\hline Government crude receipts & 17.9 & 12.8 & 12.8 & 16.3 & 15.3 \\
\hline Petroleum profit tax and royalty & 11.5 & 7.0 & 9.1 & 9.8 & 13.4 \\
\hline Petroleum profit tax & 7.6 & 4.0 & 5.8 & 6.9 & 9.2 \\
\hline Royalty & 3.9 & 3.0 & 3.3 & 2.9 & 4.2 \\
\hline Upstream gas and NLNG & 0.5 & 0.6 & 0.4 & 0.5 & 0.8 \\
\hline Other oil revenue & 0.1 & 0.4 & 0.5 & 0.2 & 0.4 \\
\hline Domestic crude & 2.5 & 5.4 & 5.1 & 6.3 & 8.0 \\
\hline Nonpetroleum revenue & 9.6 & 9.8 & 8.6 & 7.7 & 7.0 \\
\hline Tax revenue & 8.8 & 8.6 & 7.9 & 6.8 & 6.1 \\
\hline Taxes on international trade and transactions & 3.6 & 3.6 & 3.1 & 2.5 & 2.3 \\
\hline Taxes on net income, profits, and capital gains & 2.9 & 3.1 & 2.9 & 2.6 & 2.4 \\
\hline Domestic taxes on goods and services & 2.3 & 1.9 & 1.8 & 1.7 & 1.5 \\
\hline Nontax revenue & 0.8 & 1.2 & 0.7 & 0.9 & 0.9 \\
\hline Total consolidated expenditure & 47.0 & 41.4 & 37.9 & 35.9 & 33.5 \\
\hline Total federal expenditure & 31.2 & 27.1 & 22.5 & 18.6 & 19.2 \\
\hline Federal government recurrent expenditure & 22.9 & 22.3 & 19.2 & 15.5 & 15.2 \\
\hline Goods and services & 7.5 & 8.5 & 6.8 & 5.8 & 5.6 \\
\hline Personnel cost & 5.3 & 6.5 & 4.9 & 4.7 & 4.7 \\
\hline Overhead cost & 2.2 & 1.9 & 1.9 & 1.1 & 0.9 \\
\hline Pension arrears clearance & 0.0 & 0.0 & 0.0 & 0.0 & 0.0 \\
\hline Interest payments due & 6.1 & 6.4 & 4.6 & 3.6 & 3.0 \\
\hline Domestic & 2.9 & 3.0 & 2.3 & 1.9 & 1.6 \\
\hline Foreign & 3.2 & 3.4 & 2.4 & 1.7 & 1.3 \\
\hline Transfers & 9.3 & 7.4 & 7.7 & 6.0 & 6.7 \\
\hline NNPC cash calls & 7.3 & 6.1 & 6.0 & 4.6 & 5.0 \\
\hline NNPC priority projects & 0.7 & 0.1 & 0.0 & 0.0 & 0.0 \\
\hline National Judicial Council & 0.3 & 0.3 & 0.3 & 0.4 & 0.3 \\
\hline Transfer to Niger Delta Dev. Comm & 0.2 & 0.2 & 0.1 & 0.1 & 0.1 \\
\hline Customs levies & 0.5 & 0.4 & 0.5 & 0.4 & 0.2 \\
\hline Education Fund & 0.3 & 0.2 & 0.1 & 0.1 & 0.1 \\
\hline Federal government extrabudgetary funds & $\ldots$ & 0.1 & 0.6 & 0.4 & 0.8 \\
\hline Federal government capital expenditure & 8.3 & 4.7 & 3.3 & 3.2 & 4.0 \\
\hline Domestic financed & 8.1 & 4.5 & 3.2 & 3.0 & 3.8 \\
\hline Foreign financed & 0.1 & 0.2 & 0.1 & 0.2 & 0.2 \\
\hline State and local governments & 15.8 & 14.3 & 15.4 & 17.2 & 14.2 \\
\hline Primary expenditure & 15.8 & 14.3 & 14.9 & 16.6 & 13.8 \\
\hline External interest payments due & $\ldots$ & $\ldots$ & 0.4 & 0.6 & 0.4 \\
\hline Overall balance (commitment basis) 2/ & -4.9 & -5.4 & -1.3 & 5.0 & 11.4 \\
\hline Financing & 5.3 & 6.7 & 3.3 & -6.9 & -11.4 \\
\hline External & -1.1 & 0.8 & -0.3 & -0.2 & 0.0 \\
\hline Borrowing & 0.1 & 0.2 & 0.1 & 0.2 & 0.2 \\
\hline Amortization due & -3.6 & -3.0 & -2.4 & -2.3 & -2.0 \\
\hline Federal government & $\ldots$ & $\ldots$ & -2.0 & -1.7 & -1.5 \\
\hline States & $\cdots$ & $\cdots$ & -0.4 & -0.6 & -0.5 \\
\hline Arrears, rescheduling, and debt buyback & 2.3 & 3.5 & 1.9 & 1.9 & 1.8 \\
\hline Domestic & 2.6 & 6.6 & 3.4 & -7.5 & -11.5 \\
\hline Privatization proceeds & 1.6 & 0.3 & 0.0 & 0.0 & 0.2 \\
\hline Recovered funds & 0.0 & 0.0 & 0.4 & 0.8 & 0.0 \\
\hline Carryover of unspent capital mandates 3 / & 2.3 & -1.0 & -0.2 & 0.0 & 0.0 \\
\hline Statistical discrepancy & 0.4 & 1.3 & 1.9 & -1.9 & 0.0 \\
\hline \multicolumn{6}{|l|}{ Memorandum items: } \\
\hline Non-oil balance (in percent of GDP) & -30.0 & -25.4 & -23.3 & -23.6 & -21.5 \\
\hline Non-oil primary balance (in percent of non-oil GDP) 4 / & -43.2 & -31.9 & -33.8 & -37.2 & -37.5 \\
\hline Primary balance (in percent of GDP) & 1.2 & 1.0 & 3.3 & 9.2 & 14.8 \\
\hline Target for overall balance (permanent price rule, in percent of GDP) & 7.8 & 2.8 & 9.0 & 15.7 & 21.5 \\
\hline Deviation from target (permanent price rule, in percent of GDP) & -12.8 & -8.2 & -10.4 & -10.7 & -10.1 \\
\hline Nominal GDP (in billions of naira) & 5,339 & 5,632 & 7,533 & 9,309 & 11,685 \\
\hline Non-oil GDP (in billions of naira) & 2,955 & 3,365 & 4,069 & 4,856 & 5,642 \\
\hline
\end{tabular}

Source: Nigerian authorities; and Fund staff estimates and projections.

1 / State and local governments collect their own revenue (such as income tax and property tax).

2/ External debt service is on a commitment basis. Capital spending for 2002 excludes the cash overhang of $\mathrm{N} 160$ billion accumulated in 2001.

3 / This reflects the drawdown of unspent capital mandates to finance capital expenditure committed in

previous years. Insufficient data prevent the inclusion of actual commitments in 2000-01.

4/ Excluding oil revenue, cash call payments, and interest payments. 
Table 2c. Nigeria: Fiscal Accounts, Federal Government Budget, 2003-2005

\begin{tabular}{|c|c|c|c|c|c|c|c|c|c|}
\hline \multirow[b]{4}{*}{ Oil price (in U.S. dollars per barrel) } & \multirow{4}{*}{$\begin{array}{r}2003 \\
\\
\text { Est. } \\
29.0 \\
\end{array}$} & \multicolumn{6}{|c|}{2004} & \multicolumn{2}{|c|}{2005} \\
\hline & & \multirow[b]{2}{*}{ Budget } & & Q2 & Q3 & Q4 & Year & & \\
\hline & & & & & Pro & & & Prel. Budg. & Proj. \\
\hline & & 25.0 & & & & & 35.8 & 27.0 & 42.8 \\
\hline & & & & (in $\mathrm{b}$ & f naira) & & & & \\
\hline Total revenue $1 /$ & 1,014 & 1,170 & 334 & 323 & 369 & 396 & 1,422 & 1,303 & 1,975 \\
\hline Petroleum revenue & 740 & 806 & 274 & 267 & 279 & 296 & 1,115 & 988 & 1,621 \\
\hline Nonpetroleum revenue & 273 & 365 & 60 & 57 & 90 & 100 & 306 & 315 & 355 \\
\hline Import and excise duties & 95 & 106 & 25 & 25 & 23 & 22 & 95 & 114 & 114 \\
\hline Value-added tax & 20 & 23 & 5 & 6 & 6 & 6 & 23 & 26 & 26 \\
\hline Federal government independent revenue & 54 & 118 & 2 & 2 & 31 & 45 & 80 & 100 & 100 \\
\hline Customs levies & 39 & 30 & 10 & 9 & 9 & 6 & 35 & $\ldots$ & 29 \\
\hline Education tax & 10 & 18 & 4 & 1 & 3 & 4 & 12 & $\ldots$ & 10 \\
\hline Total expenditure & 1,108 & 1,239 & 180 & 338 & 309 & 330 & 1,157 & 1,572 & 1,592 \\
\hline Recurrent expenditure & 841 & 874 & 172 & 251 & 221 & 216 & 862 & 1,041 & 1,038 \\
\hline Personnel & 304 & 368 & 83 & 103 & 93 & 93 & 372 & 426 & 426 \\
\hline Pensions & 64 & 70 & 18 & 15 & 18 & 19 & 70 & 119 & 119 \\
\hline Overhead cost & 146 & 102 & 16 & 38 & 27 & 23 & 103 & 106 & 106 \\
\hline External, cash & 72 & 57 & 4 & 18 & 7 & 17 & 46 & 123 & 81 \\
\hline Transfers $2 /$ & 84 & 92 & 19 & 26 & 26 & 19 & 90 & 76 & 115 \\
\hline National Judicial Council & 26 & 30 & 4 & 10 & 13 & 6 & 33 & 33 & 33 \\
\hline Transfer to Niger Delta Development Commission & 9 & 14 & 0 & 7 & 0 & 4 & 11 & 17 & 17 \\
\hline Customs levies & 39 & 30 & 10 & 9 & 9 & 6 & 35 & $\ldots$ & 29 \\
\hline Education Fund & 10 & 18 & 4 & 1 & 3 & 4 & 12 & $\ldots$ & 10 \\
\hline UBE Commission & $\ldots$ & $\ldots$ & $\ldots$ & $\ldots$ & $\ldots$ & $\ldots$ & $\ldots$ & 26 & 26 \\
\hline Capital expenditure & 267 & 365 & 7 & 87 & 88 & 114 & 295 & 441 & 464 \\
\hline Domestic & 257 & 350 & 3 & 83 & 84 & 110 & 280 & 441 & 441 \\
\hline External & 10 & 15 & 4 & 4 & 4 & 4 & 15 & $\ldots$ & 23 \\
\hline Clearance of arrears and recapitalizations & $\ldots$ & $\ldots$ & $\ldots$ & $\ldots$ & $\ldots$ & $\ldots$ & $\ldots$ & 90 & 90 \\
\hline Overall balance (cash basis) & -95 & -68 & 154 & -15 & 60 & 66 & 265 & -269 & 384 \\
\hline Overall balance (excluding clearance of arrears and recapitalizations) & $\ldots$ & $\ldots$ & $\ldots$ & $\ldots$ & $\ldots$ & $\ldots$ & $\ldots$ & -179 & 474 \\
\hline Financing & 152 & 68 & -289 & -17 & -60 & -66 & -431 & 269 & -384 \\
\hline External & -128 & -108 & -7 & -28 & -47 & -37 & -120 & -46 & -71 \\
\hline Borrowing & 10 & 15 & 4 & 4 & 4 & 4 & 15 & $\ldots$ & 23 \\
\hline Amortization, cash & -138 & -123 & -11 & -32 & -51 & -41 & -135 & -46 & -95 \\
\hline Domestic financing & 250 & 92 & -282 & 4 & -12 & -95 & -386 & 286 & -341 \\
\hline Privatization proceeds & 0 & 0 & 0 & 0 & 0 & 0 & 0 & 19 & 19 \\
\hline Recovered funds & 30 & 84 & 0 & 7 & 0 & 67 & 74 & 10 & 10 \\
\hline Statistical discrepancy & 57 & 0 & -135 & -32 & 0 & 0 & -166 & 0 & 0 \\
\hline Memorandum items: & & & & & & & & & \\
\hline Non-oil primary balance & -593 & -631 & -82 & -213 & -161 & -168 & -624 & -943 & -966 \\
\hline Non-oil primary balance (excluding clearance of arrears) & -593 & -631 & -82 & -213 & -161 & -168 & -624 & -853 & -876 \\
\hline Budgetary revenue & 964 & 1,122 & 320 & 313 & 356 & 386 & 1,375 & 1,303 & 1,936 \\
\hline Balance on the budget (BOF definition, debt service above the line) & -222 & -176 & 147 & -43 & 12 & 28 & 145 & -315 & 312 \\
\hline & & & & (in $p$ & f GDP) & & & & \\
\hline Total revenue & 13.5 & 12.6 & & & & & 15.3 & 11.2 & 16.9 \\
\hline Petroleum revenue & 9.8 & 8.7 & & & & & 12.0 & 8.5 & 13.9 \\
\hline Nonpetroleum revenue & 3.6 & 3.9 & & & & & 3.3 & 2.7 & 3.0 \\
\hline Total expenditure & 14.7 & 13.3 & & & & & 12.4 & 13.5 & 13.6 \\
\hline Recurrent expenditure & 11.2 & 9.4 & & & & & 9.3 & 8.9 & 8.9 \\
\hline Goods and services & 6.8 & 5.8 & & & & & 5.8 & 5.6 & 5.6 \\
\hline Interest payments & 3.2 & 2.6 & & & & & 2.4 & 2.7 & 2.3 \\
\hline Transfers 2/ & 1.1 & 1.0 & & & & & 1.0 & 0.6 & 1.0 \\
\hline Capital expenditure & 3.5 & 3.9 & & & & & 3.2 & 3.8 & 4.0 \\
\hline Overall balance (cash basis) & -1.3 & -0.7 & & & & & 2.8 & -2.3 & 3.3 \\
\hline Overall balance (excluding arrears' clearance and recapitalizations) & $\ldots$ & $\ldots$ & & & & & $\ldots$ & -1.5 & 4.1 \\
\hline Financing & 2.0 & 0.7 & & & & & -4.6 & 2.3 & -3.3 \\
\hline External & -1.7 & -1.2 & & & & & -1.3 & -0.4 & -0.6 \\
\hline Domestic financing & 3.3 & 1.0 & & & & & -4.1 & 2.4 & -2.9 \\
\hline Central bank (net) & 4.9 & $\ldots$ & & & & & -5.6 & $\ldots$ & $\ldots$ \\
\hline Commercial banks (net) & -1.5 & $\ldots$ & & & & & 1.4 & $\ldots$ & $\ldots$ \\
\hline Recovered funds & 0.4 & 0.9 & & & & & 0.8 & 0.1 & 0.1 \\
\hline Statistical discrepancy & 0.8 & 0.0 & & & & & -1.8 & 0.0 & 0.0 \\
\hline Memorandum items: & & & & & & & & & \\
\hline Non-oil primary balance (in percent of non-oil GDP) & -14.6 & -13.0 & & & & & -12.8 & -16.7 & -17.1 \\
\hline Non-oil primary balance (excl. arrears' clearance, in percent of non-oil GD: & -14.6 & -13.0 & & & & & -12.8 & -15.1 & -15.5 \\
\hline Budgetary revenue & 12.8 & 12.1 & & & & & 14.8 & 11.2 & 16.6 \\
\hline Balance on the budget (BOF definition) & -3.0 & -1.9 & & & & & 1.6 & -2.7 & 2.7 \\
\hline NNPC cash calls (in millions of U.S. dollars) & 3,500 & 3,200 & & & & & 3,200 & 4,230 & 4,230 \\
\hline External debt service (FGN share, in millions of U.S. dollars) & 1,357 & 1,350 & & & & & 1,350 & 1,350 & 1,350 \\
\hline Nominal GDP (in billions of naira) & 7,533 & 9,309 & & & & & 9,309 & 11,685 & 11,685 \\
\hline Nominal non-oil GDP (in billions of naira) & 4,069 & 4,856 & & & & & 4,856 & 5,642 & 5,642 \\
\hline
\end{tabular}

Source: Authorities; and Fund staff estimates

1/ Oil revenue net of cash call payments.

2/ Excluding transfer to the NNPC for cash call payments. 
Table 3. Nigeria: Monetary Survey, 2001-05 1/2/

\begin{tabular}{|c|c|c|c|c|c|c|c|}
\hline & \multirow[t]{2}{*}{2001} & \multirow[t]{2}{*}{2002} & \multirow{2}{*}{$\begin{array}{c}2003 \\
\text { Est. }\end{array}$} & \multicolumn{2}{|c|}{$\begin{array}{c}2004 \\
\text { June }\end{array}$} & \multirow{2}{*}{$\begin{array}{r}2004 \\
\text { Proj. }\end{array}$} & \multirow[t]{2}{*}{2005} \\
\hline & & & & Auth. Prog & Est. & & \\
\hline & \multicolumn{7}{|c|}{ (In billions of naira, end of period) } \\
\hline Net foreign assets & 1,433 & 1,387 & 1,476 & 1,801 & 1,943 & 2,221 & 3,502 \\
\hline Central Bank of Nigeria (net) & 1,145 & 1,008 & 1,059 & 1,382 & 1,523 & 1,802 & 3,083 \\
\hline Commercial and merchant banks (net) & 288 & 379 & 417 & 418 & 419 & 419 & 419 \\
\hline Net domestic assets & -91 & 238 & 541 & 327 & 215 & 81 & -877 \\
\hline Net domestic credit & 830 & 1,329 & 1,765 & 1,546 & 1,485 & 1,355 & 397 \\
\hline Consolidated government (net) 3/ & 2 & 391 & 573 & 295 & 112 & -93 & $-1,356$ \\
\hline Central Bank (net, consolidated government) & -179 & -41 & 254 & -212 & -331 & -545 & $-2,056$ \\
\hline Commercial banks (net, federal government) 4/ & 154 & 415 & 298 & 507 & 422 & 431 & 679 \\
\hline Commercial banks (gross, states and local governments) & 27 & 17 & 20 & $\ldots$ & 21 & 20 & 20 \\
\hline Nonfinancial public enterprises & 1 & 0 & 0 & $\ldots$ & 0 & 0 & 0 \\
\hline Other financial institutions & 6 & 5 & 7 & $\ldots$ & 12 & 7 & 7 \\
\hline Claims on private sector 4 / & 821 & 933 & 1,185 & 1,251 & 1,361 & 1,441 & 1,746 \\
\hline Other items (net) & -921 & $-1,092$ & $-1,223$ & $-1,220$ & $-1,271$ & $-1,274$ & $-1,274$ \\
\hline Broad money & 1,316 & 1,599 & 1,985 & 2,127 & 2,113 & 2,303 & 2,625 \\
\hline \multirow[t]{2}{*}{ Bonds and money market instruments (of banks) } & 26 & 25 & 32 & & 44 & $\ldots$ & $\ldots$ \\
\hline & \multicolumn{7}{|c|}{ (Contribution to broad money growth unless otherwise stated) } \\
\hline Net foreign assets & 15.3 & -3.5 & 5.5 & 17.2 & 23.9 & 37.6 & 55.6 \\
\hline Net domestic assets & 12.6 & 25.0 & 19.0 & -18.8 & -24.1 & -23.2 & -41.6 \\
\hline Net domestic credit & 34.6 & 48.3 & 27.2 & -5.9 & -8.8 & -20.6 & -41.6 \\
\hline Net credit to the consolidated government 3 / & 11.4 & 37.6 & 11.4 & -15.4 & -24.0 & -33.5 & -54.9 \\
\hline Net credit to the federal government & 9.5 & 38.5 & 11.2 & -15.6 & -13.3 & -27.8 & -61.1 \\
\hline Claims on private sector & 23.0 & 10.8 & 15.7 & 10.1 & 15.3 & 12.9 & 13.2 \\
\hline Other items (net) & -22.0 & -13.0 & -8.2 & -13.0 & -15.4 & -2.6 & 0.0 \\
\hline Broad money (percent change since year's end) & 27.2 & 21.6 & 24.1 & 7.2 & 6.5 & 16.0 & 14.0 \\
\hline Claims on private sector (percent change since year's end) & 40.9 & 13.6 & 27.0 & 5.6 & 14.9 & 21.7 & 21.1 \\
\hline Velocity (non-oil GDP over broad money) & 2.2 & 2.1 & 2.0 & 2.3 & 2.3 & 2.1 & 2.1 \\
\hline Money multiplier & 2.4 & 2.7 & 2.9 & 3.4 & 3.4 & 3.1 & 3.2 \\
\hline Non-oil GDP at market prices (in billions of naira) & 2,955 & 3,365 & 4,069 & 4,913 & 4,913 & 4,856 & 5,642 \\
\hline Reserve money (in billions of naira) & 542 & 591 & 689 & 630 & 630 & 745 & 820 \\
\hline \multicolumn{8}{|l|}{ Memorandum item } \\
\hline Gross international reserves (in millions of U.S. dollars) & 10,423 & 7,681 & 7,468 & 10,164 & 11,441 & 13,672 & 22,494 \\
\hline
\end{tabular}

Sources: Central Bank of Nigeria (CBN); and Fund staff estimates and projections.

1/ Consolidated accounts of the CBN, commercial banks, and merchant banks.

2/ Based on the revised money and banking time series constructed by the CBN beginning in 1992

3/ Consolidated government includes the federation account; federal, state, and local governments, and special funds. The authorities in their presentation of first half 2004 outcomes (see Table $7 \mathrm{~b}$ ) have included subnational government deposit accumulation in other items net.

4/ The SM/04/194 for claims on general government (net) by banks reported N 209 billion for end-June 2004, which was incorrectly reported and should have been N 509 billion. Similarly, private sector claims was reported as N 1550 billion rather than N 1251 billion. 
Table 4. Nigeria: Balance of Payments, 2001-05

\begin{tabular}{|c|c|c|c|c|c|c|}
\hline & \multirow[t]{2}{*}{2001} & \multirow[t]{2}{*}{2002} & \multirow{2}{*}{$\begin{array}{r}2003 \\
\text { Est. }\end{array}$} & \multicolumn{2}{|c|}{2004} & \multirow{2}{*}{$\begin{array}{r}2005 \\
\text { Proj. }\end{array}$} \\
\hline & & & & CR 04/239 & Revised & \\
\hline & \multicolumn{6}{|c|}{ (In millions of U.S. dollars) } \\
\hline Trade balance & 8,116 & 4,325 & 10,435 & 13,985 & 15,449 & 20,457 \\
\hline Exports & 19,598 & 17,672 & 27,321 & 31,451 & 33,093 & 43,898 \\
\hline Oil & 18,031 & 15,878 & 24,592 & 27,860 & 29,313 & 38,813 \\
\hline Gas & 896 & 1,056 & 1,918 & 2,688 & 2,876 & 4,117 \\
\hline Other & 671 & 738 & 811 & 903 & 903 & 969 \\
\hline Imports & $-11,482$ & $-13,347$ & $-16,885$ & $-17,466$ & $-17,644$ & $-23,442$ \\
\hline Oil-related & $-1,891$ & $-3,941$ & $-5,188$ & $-3,918$ & $-4,732$ & $-4,782$ \\
\hline Gas-related & -507 & -538 & -658 & $-1,382$ & $-1,382$ & $-1,783$ \\
\hline Other & $-9,084$ & $-8,868$ & $-11,039$ & $-12,166$ & $-11,530$ & $-16,877$ \\
\hline Services and incomes balance & $-8,138$ & $-10,839$ & $-13,703$ & $-15,164$ & $-16,654$ & $-18,021$ \\
\hline Factor services balance & $-4,258$ & $-6,401$ & $-8,400$ & $-9,742$ & $-10,898$ & $-11,958$ \\
\hline Oil-related & $-2,712$ & $-4,434$ & $-5,856$ & $-7,025$ & $-8,115$ & $-8,853$ \\
\hline Gas-related & -193 & -488 & -940 & $-1,193$ & $-1,259$ & $-1,887$ \\
\hline Non oil-related & $-1,353$ & $-1,479$ & $-1,604$ & $-1,524$ & $-1,524$ & $-1,218$ \\
\hline Of which interest due on public debt & $-1,535$ & $-1,557$ & $-1,619$ & $-1,539$ & $-1,539$ & $-1,496$ \\
\hline Nonfactor services balance & $-3,880$ & $-4,438$ & $-5,303$ & $-5,422$ & $-5,756$ & $-6,063$ \\
\hline Oil-related & $-1,261$ & $-1,530$ & $-1,978$ & $-1,400$ & $-1,735$ & $-1,661$ \\
\hline Gas-related & -213 & -225 & -272 & -579 & -579 & -746 \\
\hline Non oil-related & $-2,407$ & $-2,683$ & $-3,053$ & $-3,443$ & $-3,443$ & $-3,656$ \\
\hline Private transfers (net) & 1,303 & 1,421 & 1,677 & 1,878 & 1,878 & 1,990 \\
\hline Official transfers (net) & -25 & -22 & -20 & -18 & -18 & -16 \\
\hline Current account balance & 1,255 & $-5,115$ & $-1,611$ & 681 & 654 & 4,410 \\
\hline Official capital (net) & $-1,642$ & $-1,268$ & $-1,291$ & $-1,476$ & $-1,476$ & $-1,572$ \\
\hline Disbursements & 70 & 106 & 76 & 111 & 111 & 168 \\
\hline Amortization due & $-1,713$ & $-1,373$ & $-1,368$ & $-1,587$ & $-1,587$ & $-1,740$ \\
\hline Other capital flows (net) & 2,051 & 2,484 & 3,246 & 3,508 & 4,800 & 4,548 \\
\hline Direct and portfolio investment & 2,051 & 2,484 & 3,246 & 3,508 & 4,800 & 4,463 \\
\hline Oil sector & 566 & 1,362 & 2,185 & 1,811 & 3,103 & 2,148 \\
\hline Gas sector & 351 & 370 & 440 & 1,011 & 1,011 & 1,275 \\
\hline Non-oil sector & 1,134 & 752 & 620 & 686 & 686 & 1,040 \\
\hline Private borrowing (net) & 0 & 0 & 0 & 0 & 0 & 85 \\
\hline Short-term capital (net) & -648 & -431 & -39 & 350 & 350 & 0 \\
\hline Capital account balance & -239 & 785 & 1,916 & 2,382 & 3,674 & 2,976 \\
\hline Errors and omissions & $-1,114$ & -173 & $-1,911$ & 0 & 0 & 0 \\
\hline Overall balance & -98 & $-4,503$ & $-1,606$ & 3,062 & 4,328 & 7,386 \\
\hline Financing & 98 & 4,503 & 1,606 & $-3,062$ & $-4,328$ & $-7,386$ \\
\hline Net reserves (increase -) & $-1,023$ & 2,742 & 213 & $-5,006$ & $-6,204$ & $-8,822$ \\
\hline Exceptional financing & 1,121 & 1,761 & 1,393 & 1944 & 1,876 & 1,436 \\
\hline Net accumulation of arrears (decrease -) & 375 & 1,900 & 1,177 & 1,326 & 1,326 & 1,436 \\
\hline Recovered funds $1 /$ & $\ldots$ & $\ldots$ & 216 & 618 & 550 & $\ldots$ \\
\hline Debt buyback (net) & $\ldots$ & -139 & $\ldots$ & $\ldots$ & $\ldots$ & $\ldots$ \\
\hline & \multicolumn{6}{|c|}{ (In percent of GDP; unless otherwise indicated) } \\
\hline \multicolumn{7}{|l|}{ Memorandum items: } \\
\hline Gross official reserves (in millions of U.S. dollars) & 10,423 & 7,681 & 7,468 & 12,474 & 13,672 & 22,494 \\
\hline (In months of imports (GNFS)) & 7.6 & 4.9 & 3.8 & 6.1 & 6.6 & 8.6 \\
\hline Current account & 2.6 & -11.1 & -2.8 & 1.0 & 0.9 & 5.2 \\
\hline Non-oil current account (in percent of non-oil GDP) & -41.3 & -39.6 & -42.5 & -40.2 & -38.0 & -45.7 \\
\hline Primary balance & -0.6 & -14.5 & -5.6 & -1.3 & -1.3 & 3.4 \\
\hline Primary balance (in percent of non-oil GDP) & -1.1 & -24.2 & -10.4 & -2.4 & -2.5 & 7.1 \\
\hline Trade balance & 17.0 & 9.4 & 18.1 & 20.8 & 22.3 & 24.0 \\
\hline Non-oil trade balance (in percent of non-oil GDP) & -31.9 & -29.5 & -32.9 & -31.5 & -29.4 & -38.6 \\
\hline Oil and gas sector exports & 39.7 & 36.7 & 46.1 & 45.5 & 46.5 & 50.3 \\
\hline Total imports & -24.1 & -29.0 & -29.3 & -26.0 & -25.5 & -27.5 \\
\hline Stock of external debt (in millions of U.S. dollars) & 29,686 & 30,993 & 32,818 & 32,669 & 32,669 & 32,533 \\
\hline Total external debt & 62.3 & 67.2 & 57.0 & 48.7 & 47.2 & 38.1 \\
\hline Total external debt (in percent of exports (GNFS)) 2/ & 150.2 & 144.7 & 144.5 & 121.5 & 119.2 & 89.5 \\
\hline Total external debt (in percent of consolidated revenue) & 147.9 & 186.5 & 156.1 & 108.5 & 115.5 & 85.1 \\
\hline Debt service due & 5.2 & 6.4 & 5.2 & 4.7 & 4.5 & 3.8 \\
\hline Oil export price (U.S. dollars per barrel) & 24.3 & 25.0 & 28.9 & 33.5 & 35.8 & 42.8 \\
\hline GDP (at factor cost; in millions of U.S.dollars) & 46,246 & 44,632 & 56,151 & 65,740 & 67,760 & 83,801 \\
\hline
\end{tabular}

Sources: Nigerian authorities; and Fund staff estimates and projections.

1/ For 2003, actual recovered funds received by CBN. In 2004, anticipated funds recovered by Swiss government.

2/ Three-year moving average of exports. 
Table 5. Nigeria - Oil and Gas Sector Overview, 2002-05

\begin{tabular}{|c|c|c|c|c|c|}
\hline & \multirow[t]{2}{*}{2002} & \multirow[t]{2}{*}{2003} & \multicolumn{2}{|c|}{2004} & \multirow{2}{*}{$\begin{array}{l}2005 \\
\text { Proj. }\end{array}$} \\
\hline & & & CR 04/239 & Proj. & \\
\hline \multicolumn{6}{|l|}{ Physical balances } \\
\hline & \multicolumn{5}{|c|}{ (in millions of barrels per day, unless otherwise indicated) } \\
\hline \multicolumn{6}{|l|}{ Crude oil } \\
\hline Oil price (in U.S. dollars per barrel) & 25.0 & 28.9 & 33.50 & 35.8 & 42.8 \\
\hline Production of crude oil & 1.96 & 2.45 & 2.50 & 2.46 & 2.71 \\
\hline Crude & 1.83 & 2.30 & 2.37 & 2.39 & 2.62 \\
\hline Condensates & 0.13 & 0.15 & 0.13 & 0.07 & 0.09 \\
\hline Domestic allocation to NNPC & 0.44 & 0.43 & 0.44 & 0.44 & 0.44 \\
\hline Domestic refining & 0.22 & 0.12 & 0.22 & 0.22 & 0.22 \\
\hline Exports of crude oil & 1.74 & 2.33 & 2.28 & 2.24 & 2.49 \\
\hline Of which exports out of domestic allocation & 0.23 & 0.31 & 0.22 & 0.22 & 0.22 \\
\hline OPEC quota & 1.79 & 2.01 & 2.02 & 2.02 & 2.06 \\
\hline & \multicolumn{5}{|c|}{ (in billions of cubic feet, unless otherwise indicated) } \\
\hline \multicolumn{6}{|l|}{ Natural gas } \\
\hline Total production & 1,772 & 1,819 & 2,039 & 2,007 & 2,205 \\
\hline For Nigeria Liquefied Natural Gas (NLNG) & 279 & 438 & 530 & 530 & 636 \\
\hline For natural gas liquids production (NGL) & 104 & 104 & 104 & 104 & 214 \\
\hline Other & 248 & 255 & 286 & 281 & 309 \\
\hline Reinjection & 273 & 257 & 263 & 259 & 284 \\
\hline Flaring & 667 & 864 & 857 & 833 & 762 \\
\hline Gas sales (LNG and NGL feed; in millions of barrels per day oil equivalent) & 0.19 & 0.26 & 0.31 & 0.31 & 0.41 \\
\hline Flaring (in percent of total gas produced) & 37.6 & 47.5 & 42.0 & 41.5 & 34.6 \\
\hline \multicolumn{6}{|l|}{ Financial Balances } \\
\hline & \multicolumn{5}{|c|}{ (in millions of U.S. dollars, unless otherwise indicated) } \\
\hline \multicolumn{6}{|l|}{ National accounts and balance of payments } \\
\hline \multicolumn{6}{|l|}{ Crude oil } \\
\hline Production of crude oil (including condensates) & 17,853 & 25,903 & 30,665 & 32,226 & 42,282 \\
\hline Exports & 15,878 & 24,611 & 27,951 & 29,348 & 38,813 \\
\hline Export of federation crude & 4,163 & 7,302 & 10,517 & 10,096 & 13,064 \\
\hline Foreign partner exports & 7,677 & 11,124 & 14,711 & 15,489 & 20,295 \\
\hline Domestic use & 1,974 & 1,279 & 2,701 & 2,863 & 3,469 \\
\hline Recurrent costs & 2,862 & 3,492 & 3,097 & 3,097 & 3,723 \\
\hline Investment & 3,870 & 5,326 & 3,637 & 4,929 & 4,488 \\
\hline Foreign direct investment & 1,362 & 2,185 & 1,811 & 3,103 & 2,148 \\
\hline Profit remittances $1 /$ & 4,434 & 5,856 & 7,025 & 8,115 & 8,853 \\
\hline \multicolumn{6}{|l|}{ Gas } \\
\hline Gas sales & 575 & 558 & 659 & 696 & 1,308 \\
\hline NGL 2/ & 362 & 221 & 256 & 293 & 825 \\
\hline NLNG 3/ & 213 & 337 & $40 \AA$ & 403 & 483 \\
\hline Recurrent costs & 153 & 217 & 254 & 254 & 340 \\
\hline Investment & 726 & 863 & 1,983 & 1,983 & 2,500 \\
\hline Foreign direct investment & 370 & 440 & 1,011 & 1,011 & 1,275 \\
\hline Profit remittances $4 /$ & 488 & 940 & $1,69 \hat{\theta}$ & 1,259 & 1,887 \\
\hline Oil and gas GDP (percentage change) & -11.6 & 26.6 & 3.3 & 1.9 & 12.8 \\
\hline Production of crude oil (percentage change) & -13.3 & 25.1 & 1.9 & 0.3 & 10.2 \\
\hline Gas sales (LNG and NGL feed; percentage change) & 10.5 & 41.4 & 17.0 & 17.0 & 33.9 \\
\hline \multicolumn{6}{|l|}{ Government revenue } \\
\hline \multicolumn{6}{|l|}{ Oil } \\
\hline Export of federation crude & 4,163 & 7,302 & 10,517 & 10,096 & 13,064 \\
\hline PPT & 1,852 & 3,369 & 5,204 & 4,877 & 7,851 \\
\hline Royalties, incl. rent & 1,391 & 1,899 & 2,482 & 2,497 & 3,591 \\
\hline Domestic crude $\&$ tax on petroleum products & 2,381 & 2,813 & 5,456 & 5,463 & 6,775 \\
\hline Miscellaneous oil revenue (pipeline fees) & 172 & 254 & 259 & 255 & 280 \\
\hline Gas & & & & & \\
\hline NGL & 177 & 108 & 126 & 192 & 404 \\
\hline LNG feed gas & 105 & 165 & 209 & 209 & 251 \\
\hline Flaring 5/ & 33 & 37 & 61 & 62 & 55 \\
\hline Government share of costs & 3,088 & 3,500 & 3,200 & 3,200 & 4,230 \\
\hline Net oil and gas revenue & 7,186 & 12,448 & 21,114 & 20,451 & 28,041 \\
\hline
\end{tabular}

Sources: Nigerian authorities; and Fund staff estimates.

1/ Calculated as foreign partner exports minus PPT and royalties minus foreign partner share of operating costs.

2/ NNPC data for 2002-03. Projection calculated as NGL export revenue minus operating and capital cost (netback value for feed gas).

3/ NNPC data for 2002-03. Projection assumes price of US\$0.68 per cubic feet of feed gas.

4/ Calculated as foreign partner share of dividends for LNG; foreign partner share in feed gas delivery for NGL.

5/ NNPC data for 2002-03. Projection calculated as residual and assuming a price of N10 per cubic feet. 
Table 6: Nigeria: Quarterly Federal Government Budget (Cash Basis), Authorities' Program, 2004

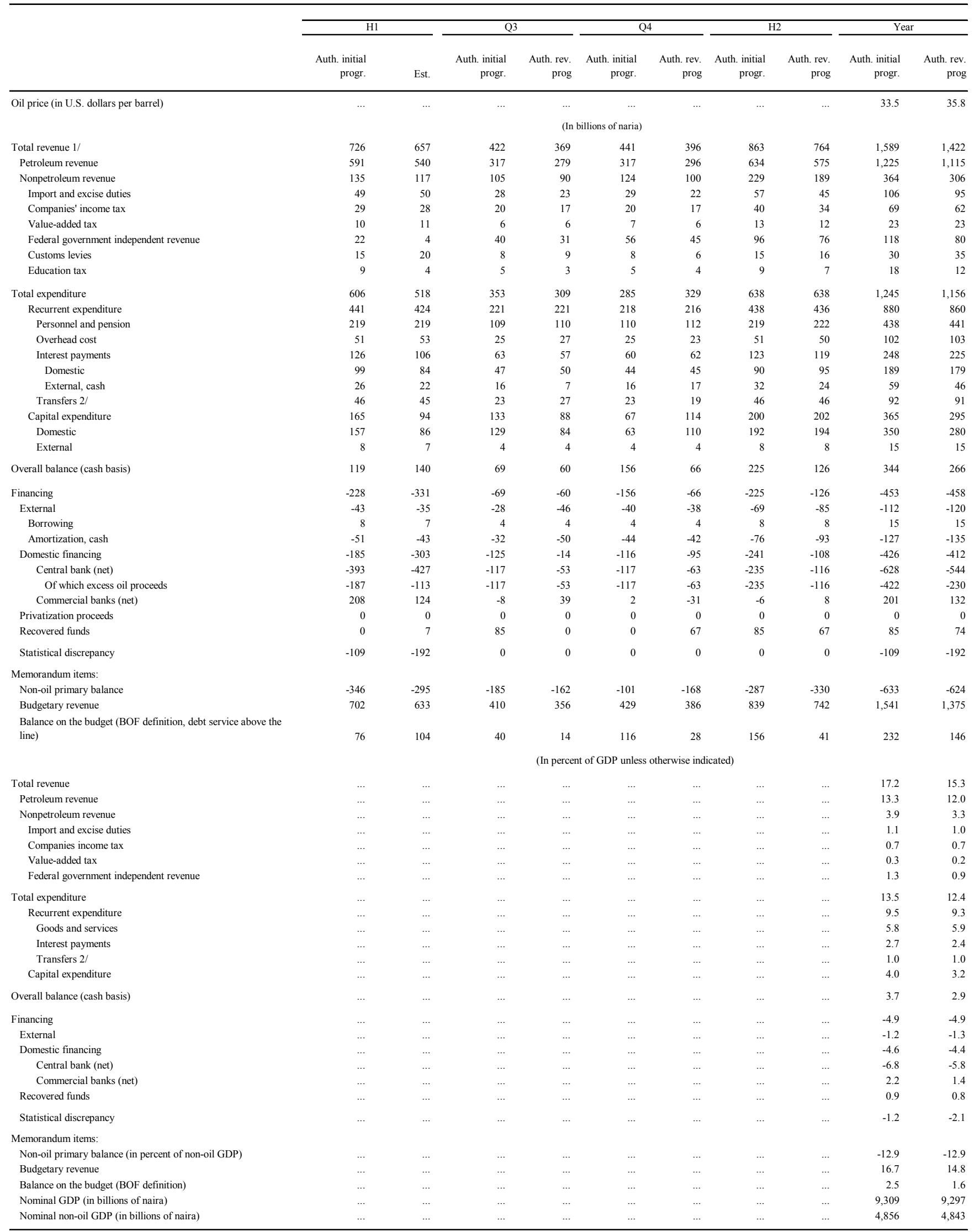

Sources: Nigerian authorities; and Fund staff estimates and projections.

1/ Oil revenue net of cash call payments.

2/ Excluding transfer to the NNPC for cash call payments. 
Table 7a. Nigeria: Central Bank of Nigeria's 2004 Program: Monetary Authorities Balance Sheet, 2003-04 1/

(In billions of naira, unless otherwise indicated)

\begin{tabular}{|c|c|c|c|c|c|c|c|}
\hline & \multicolumn{2}{|l|}{2003} & \multicolumn{5}{|c|}{2004} \\
\hline & \multirow[t]{2}{*}{ Dec. } & \multirow{2}{*}{$\begin{array}{l}\text { Mar. } \\
\text { Est. }\end{array}$} & \multicolumn{2}{|l|}{ Jun } & \multicolumn{2}{|c|}{ Sept. } & \multirow{2}{*}{$\begin{array}{r}\text { Dec } \\
\text { Auth.initial } \\
\text { program }\end{array}$} \\
\hline & & & $\begin{array}{r}\text { Auth.initial } \\
\text { program }\end{array}$ & Est. & $\begin{array}{r}\text { Auth.initial } \\
\text { program }\end{array}$ & $\begin{array}{r}\text { Auth. Rev. } \\
\text { Prog }\end{array}$ & \\
\hline Net foreign assets & $1,059.1$ & $1,259.3$ & $1,293.7$ & $1,517.2$ & $1,459.6$ & $1,547.7$ & $1,607.8$ \\
\hline Foreign assets & $1,065.1$ & $1,347.9$ & $1,382.3$ & $1,573.2$ & $1,548.2$ & $1,631.6$ & $1,696.4$ \\
\hline Foreign liabilities & -6.0 & -88.6 & -88.6 & -56.0 & -88.6 & -83.9 & -88.6 \\
\hline Net domestic assets & -370.4 & -624.3 & -663.9 & -862.7 & -746.9 & -834.2 & -862.5 \\
\hline Domestic credit & 42.8 & -11.3 & -318.5 & -104.7 & -483.1 & -293.3 & -593.7 \\
\hline Government (net) 2/ & 254.2 & -23 & -212.2 & -99.2 & -329.3 & -281.1 & -446.7 \\
\hline Claims on deposit money banks & 15.6 & 94.0 & 30.0 & 94.0 & 30.0 & 96.6 & 30.0 \\
\hline Other Net Claims & -226.9 & -87.2 & -136.3 & -99.5 & -183.9 & -108.8 & -177.1 \\
\hline Claims on state and local governments (net) $2 /$ & 0.0 & 0.0 & -46.8 & 0.0 & -94.4 & 0.0 & -111.6 \\
\hline Claims on non-financial private sector (net) & 1.7 & 1.7 & 0.0 & 1.6 & 0.0 & 0.0 & 0.0 \\
\hline Claims on other financial institutions (net) & 6.8 & 11.3 & 11.1 & 11.2 & 11.1 & 0.0 & 11.1 \\
\hline Claims on non-financial public enterprises (net) & -235.4 & -100.1 & -100.6 & -112.3 & -100.6 & -108.8 & -76.6 \\
\hline Other items net & -413.2 & -613.0 & -345.5 & -758.0 & -263.8 & -540.9 & -268.8 \\
\hline Reserve money & 688.7 & 635.0 & 629.7 & 654.5 & 712.7 & 713.5 & 745.3 \\
\hline Currency in circulation & 502.3 & 466.5 & 452.9 & 456.3 & 458.8 & 458.8 & 512.9 \\
\hline Bank deposits with CBN & 186.4 & 168.5 & 176.8 & 198.2 & 254.0 & 254.7 & 232.4 \\
\hline \multicolumn{8}{|l|}{ Memorandum items: } \\
\hline \multicolumn{8}{|l|}{ Reserve Money } \\
\hline 12-month rate & 16.4 & 2.9 & 2.9 & 0.2 & 12.6 & 12.7 & 8.2 \\
\hline Month-on-month percent change & 4.3 & 0.5 & -1.7 & 3.3 & 1.2 & 8.6 & 3.5 \\
\hline Percent change since end-2003 & $\ldots$ & -7.8 & -8.6 & -5.0 & 3.5 & 3.6 & 8.2 \\
\hline Gross reserves (in millions of U.S. dollars, BAPLA) & 7,468 & 9,643 & 10,164 & 11,400 & 11,384 & 12,280 & 12,474 \\
\hline
\end{tabular}

Source: Nigerian authorities' figures and projections.

1/ Consistent with the baseline assumption that the federal government and 12 out of 36 states save the oil revenue windfall

in the second half of 2004 and that all states and the Federal government save the first half windfall.

2/ The authorities presented in SM/04/194 in Table 8a their monetary program seperating subnational excess oil proceeds and extrabudgetary funds

from federal government deposits starting in the second quarter . However, in their revised monetary program, the CBN includes subnational and

extrabudgetary funds excess oil proceeds and accounts as part of other liabilities and hence other items net. 
Table 7b. Nigeria: Central Bank of Nigeria's 2004 Revised Monetary Program: Monetary Survey, 2003-2004 1/

(In billions of naria, end of period, unless otherwise stated)

\begin{tabular}{|c|c|c|c|c|c|c|c|c|}
\hline & \multirow{3}{*}{$\begin{array}{c}2003 \\
\text { Dec. }\end{array}$} & \multicolumn{7}{|c|}{2004} \\
\hline & & \multirow[t]{2}{*}{ Mar. } & \multicolumn{2}{|c|}{ Jun. } & \multicolumn{2}{|c|}{ Sep. } & \multicolumn{2}{|c|}{ Dec. } \\
\hline & & & $\begin{array}{r}\text { Auth.initial } \\
\text { program }\end{array}$ & $\begin{array}{r}\text { Auth. Rev. } \\
\text { Prog } \\
\end{array}$ & $\begin{array}{r}\text { Auth.initial } \\
\text { program }\end{array}$ & Auth. Rev. Prog & $\begin{array}{r}\text { Auth.initial } \\
\text { program }\end{array}$ & Auth. Rev. Prog \\
\hline 1.Domestic Credit (net) & 1,765 & 1,755 & 1,561 & 1,717 & 1,642 & 1,571 & 1,599 & 1,448 \\
\hline (a) Claims on Federal Government (net) 2/ & 553 & 434 & 295 & 323 & 175 & 141 & 53 & -30 \\
\hline By Central Bank & 254 & -23 & -212 & -99 & -329 & -281 & -447 & -453 \\
\hline By Banks (FGN) & 298 & 457 & 507 & 422 & 504 & 422 & 500 & 422 \\
\hline (b).Claims on Private Sector 3/ & 1,212 & 1,321 & 1,266 & 1,394 & 1467 & 1430 & 1546 & 1479 \\
\hline By Central Bank & 9 & 13 & 11 & 14 & 11 & 10 & 11 & 11 \\
\hline By Banks & 1,203 & 1,308 & 1,255 & 1,380 & 1456 & 1420 & 1535 & 1468 \\
\hline (2) Foreign Assets (net) & 1476 & 1677 & 1712 & 1937 & 1878 & 1967 & 2026 & 2152 \\
\hline By Central Bank 2/ & 1059 & 1259 & 1294 & 1517 & 1460 & 1548 & 1608 & 1733 \\
\hline Foreign Assets & 1065 & 1348 & 1382 & 1573 & 1549 & 1632 & 1696 & 1817 \\
\hline Short term Liabilities & 6 & 89 & -89 & -56 & -89 & -84 & -89 & -84 \\
\hline By Banks & 417 & 418 & 418 & 419 & 418 & 419 & 418 & 419 \\
\hline (3) Other Assets (net) & -1255 & -1325 & -1145 & -1540 & -1335 & -1335 & -1322 & -1297 \\
\hline Total Monetary Assets & 1985 & 2106 & 2127 & 2113 & 2185 & 2204 & 2303 & 2303 \\
\hline Quasi-Money & 760 & 920 & 837 & 898 & 867 & 855 & 908 & 895 \\
\hline Narrow Money & 1,226 & 1,202 & 1,291 & 1215 & 1,318 & 1,348 & 1,395 & 1,409 \\
\hline Currency Outside Banks & 412 & 384 & 396 & 373 & 383 & 373 & 419 & 433 \\
\hline Demand Deposits & 813 & 817 & 895 & 842 & 935 & 975 & 976 & 976 \\
\hline \multicolumn{9}{|l|}{ Memoramdum items } \\
\hline & \multicolumn{8}{|c|}{ Growth rate over preceeding December (in percent) } \\
\hline Credit to the Domestic Economy (net) & & -0.6 & -11.5 & -2.7 & -6.9 & -10.9 & -9.4 & -17.9 \\
\hline Claims on General Government (net) & & -21.5 & -46.7 & -41.5 & -68.3 & -74.4 & -90.4 & -105.5 \\
\hline By Central Bank & & -109.1 & -183.5 & -139.0 & -229.6 & -210.6 & -275.9 & -278.1 \\
\hline By Deposit Money Banks & & 53.0 & 69.9 & 41.5 & 68.9 & 41.5 & 67.5 & 41.5 \\
\hline Credit to the Private Sector & & 9.0 & 4.5 & 15.0 & 21.0 & 18.0 & 27.6 & 22.0 \\
\hline Foreign Assets (net) & & 13.7 & 16.0 & 31.2 & 27.2 & 33.3 & 37.3 & 45.8 \\
\hline Other Assets (net) & & -4.5 & 8.8 & -21.6 & -6.4 & -6.4 & -5.3 & -3.3 \\
\hline Broad Money (M2) & & 6.1 & 7.1 & 7.2 & 10.1 & 11.0 & 16.0 & 16.0 \\
\hline Quasi-Money & & 21.1 & 10.2 & 20.1 & 14.1 & 12.6 & 19.5 & 17.8 \\
\hline Money Supply (M1) & & -2.0 & 5.3 & -0.9 & 7.5 & 10.0 & 13.8 & 15.0 \\
\hline
\end{tabular}

Source: The Nigierian authorities' figures and projections

1/ This scenario assumes that the Federal government and 12 out of 36 states save the oil revenue windfall in the second half of 2004,

but that all tiers of government save the first half windfall.

2/ The CBN and the staff's presentation of the CBN balance sheet and monetary survey differ in a number of ways.

Staff shows net claims of the of both the federal government and subnational governments consistent with the fiscal presentation of

the government. The CBN includes deposits of the subnational governments in narrow and quasi money and only shows gross claims

of the subnational governments in the monetary survey. In the CBN's own balance sheet, deposits of subnational governments

and extrabudgetary funds are included in other items net (other liabilities). This differs with their presentation of their program in SM/04/194,

where the $\mathrm{CBN}$ showed the subnational government deposits with the $\mathrm{CBN}$ as part of the consolidated (general) government and hence

makes it difficult to compare the figures.

3 / Includes claims on subnational governments. 


\section{Nigeria: Relations with the Fund}

(As of August 31, 2004)

I. Membership Status: Joined: 03/30/1961; Article XIV

II. General Resources Account:

Quota

Fund Holdings of Currency

Reserve position in the Fund

III. SDR Department:

Net cumulative allocation

Holdings
SDR Million

$1,753.20$

$1,753.12$

0.14

SDR Million

157.16

0.05
\%Quota

100.00

100.00

0.01

\%Allocation

100.00

0.03

IV. Outstanding Purchases and Loans: None

V. Latest Financial Arrangements:

\begin{tabular}{|c|c|c|c|c|}
\hline Type & $\begin{array}{l}\text { Approval } \\
\text { Date }\end{array}$ & $\begin{array}{l}\text { Expiration } \\
\text { Date }\end{array}$ & $\begin{array}{l}\text { Amount Approved } \\
\text { (SDR Million) }\end{array}$ & $\begin{array}{r}\text { Amount Drawn } \\
\text { (SDR Million) }\end{array}$ \\
\hline Stand-by & Aug. 04, 2000 & Oct. 31,2001 & 788.94 & 0.00 \\
\hline Stand-by & Jan. 09, 1991 & Apr. 08, 1992 & 319.00 & 0.00 \\
\hline Stand-by & Feb. 03, 1989 & Apr. 30,1990 & 475.00 & 0.00 \\
\hline
\end{tabular}

VI. Projected Obligations to Fund:(SDR Million; based on existing use of resources and present holdings of SDRs):

Principal

Charges/Interest

Total

\begin{tabular}{lllll} 
& \multicolumn{3}{c}{ Forthcoming } \\
\cline { 2 - 5 } 2004 & $\underline{2005}$ & $\underline{2006}$ & $\underline{2007}$ & $\underline{2008}$ \\
$\underline{0.77}$ & $\underline{3.08}$ & $\underline{3.08}$ & $\underline{3.08}$ & $\underline{3.08}$ \\
$\underline{0.77}$ & $\underline{3.08}$ & $\underline{3.08}$ & $\underline{3.08}$ & $\underline{3.08}$
\end{tabular}

\section{Exchange Rate Arrangement:}

Nigeria's current exchange rate arrangement is classified in the Fund's Annual Report on Exchange Arrangements and Exchange Restrictions as a managed float with no preannounced target for the exchange rate of the naira. The inter-bank foreign exchange market is segmented into two sub-markets. The Central Bank of Nigeria (CBN) sells foreign exchange to legitimate end-users through banks that bid, with requests having to be supported by the required documentation. The open Nigerian inter-bank market (NIFEX) is the market for foreign exchange obtained from other sources than the CBN, including nonoil exports and personal transfers, and the NIFEX rate is freely negotiable among commercial banks as well as among customers. On February 20, 2001, the CBN issued a circular which forbid banks from transferring funds obtained from the CBN to other banks through the NIFEX, effectively segmenting the two markets. On July 22, 2002, the 
authorities adopted the Dutch Auction System (DAS) for selling official foreign exchange to end-users. The DAS is a sealed bid multiple price auction system with the marginal rate being the rate that clears the market. Auctions take place twice a week and the CBN announces the amount on offer the day before the auction and the auction results the day after. Funds purchased from the CBN shall be used for eligible transactions only, subject to stipulated documentation requirements. Such funds are not transferable in the inter-bank foreign exchange market.

Currently, there are four exchange rates: the DAS auction rate, the NIFEX rate quoted by a group of commercial banks, the Bureaux de change rate, and the parallel market rate.

The following exchange rates were quoted on October 1, 2004:

$\begin{array}{ll}\text { IFEM/DAS } & \mathrm{N}=\text { US } \$ 133.4 . \\ \text { NIFEX } & \mathrm{N}=\text { US } \$ 134.3 . \\ \text { Bureaux de change/parallel market } & \mathrm{N}=\text { US } \$ 139.5 .\end{array}$

The exchange rate for the SDR on October 1, 2004 was N176.6 = SDR 1.

\section{Article IV Consultation}

Nigeria is on the standard 12-month Article IV consultation cycle. The last Article IV consultation discussions were held in Lagos and Abuja during the period February 23March 8 and May 12-19, 2004. The staff report (IMF Country Report No. 03/3) was discussed by the Executive Board and the consultation concluded on July 16, 2004.

\section{Technical Assistance (TA) Since 2000:}

\section{Department Purpose of TA mission}

FAD Fiscal regime for oil and gas

STA

FAD

FAD

FAD

STA

FAD

STA

MAE

FAD

MAE

MAE

FAD

STA

FAD

MFD

STA
Balance of payments statistics

Resident treasury advisor

Resident budget advisor

Fiscal federalism

Government finance statistics

Expenditure Management

Money and banking statistics

Foreign exchange management

Resident budget advisor

FSAP

FSAP

Public Expenditure Management

Government Finance Statistics

Resident budget advisor

Domestic Debt Management

General Data Dissemination Standards

\section{Duration}

February 8-26, 2000

November 8-21, 2000

November. 25, 2000-Feb. 25-2001

and April 8-July 7, 2001

January 11-March 11, 2001

January 24-Feb. 11, 2001

January 21-Feb. 3, 2001

February 2-10, 2001

March 22-April 4, 2001

May 28-June 8, 2001

October 2000 - Dec. 2001

Dec. 5 - Dec. 15, 2001

Feb. 4 - Feb. 20, 2002

January 29 - February 8

Feb. 28 - March 13, 2002

Apr. 19 2002- June, 2003

February 25-March 5, 2003

July 2-15, 2003 
FAD Budget Process Reforms

FAD Pension Reform

FAD Public Expenditure Management Advisor

MFD Domestic Debt Management

LEG FIU Creation and Organization

LEG Legislative Drafting/FIU

STA Regional Course on National Accounts and Balance of Payments Statistics

FAD Tax Administration

MFD

MFD
Financial Sector Reform

Monetary Operations/Foreign Exchange
August 20-29, 2003

October 20-29, 2003

January-December 2004

February 5-17, 2004

May 31-June 04, 2004

July 12-16, 2004

July 25-August 6,2004

July 19-August 3, 2004

August 10-17,2004

August 26-September 10, 2004

\section{Resident Representative:}

Mr. Idrissa Thiam has entered on duty as Senior Resident Representative in Abuja on December 20, 2003. 


\section{Nigeria: Relations with the World Bank Group}

\section{World Bank Strategy of Assistance to Nigeria}

1. The Joint Interim Strategy, endorsed by the Board in 2001, has been guiding the Bank assistance to Nigeria. The strategy is articulated around three main pillars: (i) improving economic governance; (ii) promoting accelerated private sector led growth, particularly in the non-oil economy and (iii) empowering communities to take an active role in their own development.

2. A Second Interim Strategy Progress Report was discussed by the Board on June 15, 2004. The Board endorsed the expanded World Bank engagement in Nigeria and in particular, a move from the low case lending envelope of \$200 million annually to the base case of $\$ 500$ million on average per annum.

3. The Bank's assistance will continue to be developed based on the three pillars, while non-lending support will focus on areas such as public expenditure management, anticorruption, health, education, and delivery of basic services. A full results oriented Country Assistance Strategy (CAS) will be developed this fiscal year (FY05) based on and in support of the Government's National Economic Empowerment and Development Strategy (NEEDS). The CAS is being prepared in a participatory manner with government, and the involvement of development partners and stakeholders.

\section{World Bank-IMF relations}

4. The IMF and World Bank staffs maintain a close collaborative relationship on Nigeria. Both institutions are coordinating their policy advice to the government in several different areas through collaboration on analytical work, and through joint technical assistance missions. The Bank staff is regularly invited to join IMF macroeconomic missions, and both are members of a multi-donor thematic group on economic governance that seeks to coordinate donor advice and work in this area.

5. In September 2003, at the request of the Nigerian government, the Bank and the IMF carried out a joint technical assistance mission for the Budget Office. A similar joint mission to advice government on the proposed Pension Reform Bill was carried out in November 2003. Support to the preparation of the NEEDS is also another area of close collaboration between the two institutions.

6. Under the erstwhile Stand-By Arrangement, the IMF took the lead in the area of macroeconomic stability with the dialogue on structural measures, coordinated with the World Bank. In the absence of a successor IMF-supported program, a detailed matrix stipulating areas where each institution will take the lead in supporting key structural measures, including several areas of joint responsibility such as fiscal transparency, fiscal federalism, budget procedures and institutions, and public debt management, has not been agreed. 


\section{Lending activities}

7. The World Bank's Nigeria portfolio consists of fifteen credits, totaling about $\$ 1.2$ billion. Operations cover activities in Health (20 percent ), Education (12.7 percent), Private Sector Development (11.9 percent), Urban Development (9 percent), Rural Sector (13.8 percent); Transport ( 8 percent) Energy \& Mining (8 percent) Social Development/Social Protection (4.9 percent), Economic Policy (1.6 percent), and Water Supply \& Sanitation ( 9.8 percent).

8. Two credits in the portfolio (the Economic Management and Capacity Building Project and the Privatization Support Project) are focused on economic management and on support for the government's privatization effort. An operation to support a first phase of the Federal Government's Economic Reform and Governance Program is expected to be ready for Board approval in December 2004. A States Governance and Capacity Building Project which will focus on building economic management capacity and on civil service reform at the state level, is expected to be ready for approval also in early FY05.

9. The Economic Management and Capacity Building Project (US\$20 million in IDA financing, and cofinancing of US\$19.6 million from the U.S. Agency for International Development, the U.K. Department for International Development, the European Union, and Japan) was approved on May 11, 2000. It supports the strengthening of key aspects of economic management, including economic and poverty statistics, public expenditure management, public procurement, and external audit and oversight of federal government fiscal operations - including by the legislature - and legal and judicial reform. Under this project, value-for-money audits of selected items of federal government spending (both recurrent and capital) and a corruption survey have been carried out. Other key activities that are being supported include the revision of the 1958 Finance (Management and Control) Act, implementation of procurement reforms, installation of an integrated Financial and Economic Management Information System, and construction of a global distance-learning center.

10. For the Privatization Support Operation, the World Bank Board approved the $\$ 114.29$ million equivalent of IDA credit on June 14, 2001. The aim of this project is to strengthen the overall institutional and policy framework for public enterprise divestiture and improve the institutional capacity of the Bureau of Public Enterprises, the agency responsible for privatization. The project also provides financing for advisory services for privatization of the power sector (the Nigerian Electric Power Authority) and the telecommunications sector (divestiture of the national telecommunications companies, NITEL and M-Tel). In addition, the project supports the divestiture of Lagos State Water through concessioning (an IFC mandate) and rehabilitation of the water supply system in Lagos. A mid-term review of the project that took place from March 26-April 6, 2004 agreed on details of reallocation of resources and monitoring of results, which will enable a more focused and efficient project implementation. 


\section{Nonlending Activities}

11. The World Bank has placed increased emphasis on its non-lending activities. Work in this area has focused on public expenditure management - through public expenditure reviews at both federal and state levels, a report on state finances, and a report on the states' governance and capacity. Other elements of this work include collaboration with the Debt Management Office on Management of Sub-national Debt; a report on managing volatility; a pilot survey of service delivery in basic health in Lagos and Kogi States; a private sector assessment; a rural sector strategy; and a report on the linkages between environment and poverty. Bank staff worked closely with various policy groups, within and outside government on outlining key reform and development priorities and actions. An Education Sector Status Report was completed in FY03 and is Risk and Vulnerability Assessment is to be completed in FY04. Work is ongoing on a study on Oil Revenues Management including a workshop in February 2004 - in collaboration with the IMF - to bring together various Nigerian stakeholders as well as external experts on this issue. A study on the micro foundations of competitiveness in specific industries is also in process.

\section{International Finance Corporation (IFC) Activities}

12. Nigeria is IFC's largest country portfolio in Africa with US\$289 million committed with activities in various sectors including finance and insurance; oil, gas and mining; private equity funds. IFC continues to encourage and support Small and Medium Enterprises (SMEs), and invests in private sector development, including the banking industry and infrastructure.

13. IFC also seeks to promote projects that will assist Nigeria in diversifying its economy from the oil sector and removing bottlenecks faced by the non-oil private sector. IFC activities include:

14. Small and Medium Enterprises (SMEs): IFC provides a broad range of financing and technical support to small businesses in Nigeria. Jointly with UNIDO, support was provided to NGOs (the FATE Foundation and the Onitsha/Nnewi/Aba Cluster program) through the Support Training Entrepreneurship Program (STEP), which provides business development services to micro enterprises. Other initiatives include a financing and capacity-building facility for small-scale oil service companies in the Niger Delta region. A comprehensive program with support from the World Bank is also being designed to provide additional support for small business access to finance, business development services and for help in improving the SME business environment.

15. Telecommunications Sector: In FY02 IFC approved an investment of \$100 million for MTN Nigeria, a large mobile telecommunication company, for the expansion of its nationwide GSM (Global System for Mobile Communications) cellular telecommunications network in Nigeria, and by February 2006, the company expects to have well in excess of $15,000,000$ subscribers in accordance with its license requirements. IFC is playing role of fostering competition, supporting private sector development, and improve the telecommunications market and services. 
16. Financial Sector: Since scaling up of IFC operations began in 1999-2000, IFC has worked with seven commercial banks, extending term facilities totaling over $\$ 160$ million. With no long-term funding options available in Nigeria, banks have used the IFC credits to offer medium-term financing to a range of clients in expanding their businesses. IFC is expanding this relationship with leading banks to support more small business financing options, and also to build the nascent corporate bond market.

\section{World Bank Institute activities (WBI)}

17. Nigeria is one of the WBI's six focus countries in Africa. The number of Nigerian participants in WBI programs has significantly increased in the last two years (from 280 participants in FY01, to 1,600 in FY04). The sharp increase in the number of participants was due to the increased use of Distance Learning as a delivery mode and the larger number of events held locally. The professional groups and communities of practice that took the fullest advantage of WBI programs were public expenditure managers, individuals involved in social protection/social risk management programs, parliamentarians, and journalists. This concentration of efforts is in line with the World Bank's strategy to help Nigeria manage its public resources and help strengthen the voice of the poor at the community level. However, irrespective of the well-targeted WBI assistance, it is unlikely to make a lasting impact on capacity, if the Institute does not adequately leverage its efforts with those of the Africa Region and other development partners. For this reason, the Institute is taking steps to increase its involvement in the context of the WBI Country Program Brief endorsed by the Nigeria Country Team. Thematically, in coming years, the WBI program will be more focused on developing the capacity of members of the civil society working to make their voices heard and forge a national consensus. For this reason, the Institute is carrying out a major effort to identify capacity building needs at the community level through the Capacity Enhancement Needs Assessment (CENA) methodology. The pursuit of the World Bank's strategic objectives has also led to a better integration of WBI staff into the Nigeria Country Team and IDA project teams.

\section{Multilateral Investment Guarantee Agency (MIGA)}

18. MIGA's gross exposure in Nigeria is $\$ 112.8$ million and net exposure is $\$ 90.9$ million. There are seven contracts issued for investors in Nigeria (two contracts in the services sector and five contracts in the infrastructure sector). 
Nigeria: IDA Credits in the Operations Portfolio

(As of October 7, 2004)

Closed Projects: 98

Difference Between

Active Projects

$\underline{\text { Original Amount in US\$ mil Disbursements a/ }}$

\begin{tabular}{|c|c|c|c|c|c|c|}
\hline Project ID & Project Name & Fiscal Year & $\begin{array}{c}\text { Approved IDA } \\
\text { Amount }\end{array}$ & Undisbursed & Orig. & Frm Rev'd \\
\hline P070290 & 2nd Health Systems Dev. & 2002 & 127.00 & 134.2 & 54.47 & 3.59 \\
\hline P066571 & 2nd Primary Education & 2000 & 55.00 & 14.0 & 11.35 & 11.35 \\
\hline P069086 & Com.-Based Pov. Reduction & 2001 & 60.00 & 42.9 & 15.92 & 10.42 \\
\hline P069901 & Community Based Urban Dev. & 2002 & 110.00 & 123.8 & 55.26 & 29.31 \\
\hline P065301 & Economic Mgt Capacity Building & 2000 & 20.00 & 6.3 & -2.08 & \\
\hline P070291 & HIV/AIDS Program Dev. & 2002 & 90.30 & 90.4 & 39.91 & \\
\hline P083082 & Micro, Small \& Med. Enterprise & 2004 & 32.00 & 32.6 & 2.70 & \\
\hline P074963 & Lagos Urban Transport Project & 2003 & 100.00 & 99.7 & 24.07 & 14.88 \\
\hline P069892 & Local Empowerment \& Envir. Mgmt. & 2004 & 70.00 & 75.4 & 4.74 & 0.40 \\
\hline P070293 & Privatization Support & 2001 & 114.29 & 105.1 & 51.49 & \\
\hline P063622 & Fadama II & 2004 & 100.00 & 95.8 & 6.81 & \\
\hline P072018 & Transmission Development & 2002 & 100.00 & 94.8 & 65.83 & 39.58 \\
\hline P080295 & Polio Eradication & 2003 & 28.70 & 1.3 & 10.71 & \\
\hline P071494 & Universal Basic Ed. & 2003 & 101.00 & 110.4 & 69.67 & \\
\hline P071075 & Urban Water Sector Reform & 2004 & 120.00 & 120.8 & 6.36 & \\
\hline \multicolumn{3}{|c|}{ Overall Result } & 1228.29 & 1155.21 & 418.55 & 109.45 \\
\hline
\end{tabular}

IBRD/IDA *

Total Disbursed (Active) of which has been repaid

Total Disbursed (Closed) of which has been repaid

Total Disbursed (Active + Closed) of which has been repaid

Total Undisbursed (Active)

Total Undisbursed (Closed)

Total Undisbursed (Active + Closed)
US\$ mil

199.94
0.00
$6,032.82$
$5,244.30$
$6,232.75$
$5,244.30$
$1,147.46$
0.00
$1,147.46$

Note: Undisbursed amount may be higher than Approved amount due to exchange rate vis-à-vis SDR.

a/ Intended disbursements to-date minus actual disbursements to-date as projected at appraisal

* Disbursement data is updated at the end of the first week of the month. 
International Finance Corporation

\section{Nigeria - Statement of IFC's Held and Disbursed Portfolio}

Amounts in US Dollar Millions

As of August 31, 2004

\begin{tabular}{lrrrrrrrrr}
\hline & \multicolumn{4}{c}{ Held } & \multicolumn{5}{c}{ Disbursed } \\
FY Approval Company & Loan & \multicolumn{1}{c}{ Equity } & Quasi & Partic. & Loan & Equity & Quasi & Partic. \\
\hline 1998AEF Ansbby & 0.1 & 0.0 & 0.0 & 0.0 & 0.1 & 0.0 & 0.0 & 0.0 \\
1999AEF Global Fabri & 0.3 & 0.0 & 0.0 & 0.0 & 0.3 & 0.0 & 0.0 & 0.0 \\
1999AEF Hercules & 1.3 & 0.0 & 0.0 & 0.0 & 1.3 & 0.0 & 0.0 & 0.0 \\
1999AEF Hygeia & 0.0 & 0.2 & 0.0 & 0.0 & 0.0 & 0.2 & 0.0 & 0.0 \\
2000AEF Oha Motors & 0.8 & 0.0 & 0.0 & 0.0 & 0.8 & 0.0 & 0.0 & 0.0 \\
1997AEF Radmed & 0.0 & 0.0 & 0.0 & 0.0 & 0.0 & 0.0 & 0.0 & 0.0 \\
2000AEF Safety Center & 0.5 & 0.1 & 0.0 & 0.0 & 0.5 & 0.1 & 0.0 & 0.0 \\
1997AEF Telipoint & 0.1 & 0.0 & 0.0 & 0.0 & 0.1 & 0.0 & 0.0 & 0.0 \\
1995AEF Vinfesen & 1.0 & 0.0 & 0.0 & 0.0 & 1.0 & 0.0 & 0.0 & 0.0 \\
1994Abuja International & 1.8 & 0.7 & 0.0 & 0.0 & 1.8 & 0.7 & 0.0 & 0.0 \\
2003Adamac & 25.0 & 0.0 & 0.0 & 15.0 & 11.6 & 0.0 & 0.0 & 6.9 \\
2000CAPE FUND & 0.0 & 7.5 & 0.0 & 0.0 & 0.0 & 5.4 & 0.0 & 0.0 \\
2000Citibank (Nig) & 6.4 & 0.0 & 0.0 & 0.0 & 6.4 & 0.0 & 0.0 & 0.0 \\
2001Delta Contractor & 15.0 & 0.0 & 0.0 & 0.0 & 0.2 & 0.0 & 0.0 & 0.0 \\
2000Diamond Bank & 10.0 & 0.0 & 0.0 & 0.0 & 10.0 & 0.0 & 0.0 & 0.0 \\
2000FSB & 9.5 & 0.0 & 11.3 & 0.0 & 9.5 & 0.0 & 6.8 & 0.0 \\
1992FSDH & 0.0 & 0.9 & 0.0 & 0.0 & 0.0 & 0.9 & 0.0 & 0.0 \\
GTB & 20.0 & 0.0 & 0.0 & 0.0 & 0.0 & 0.0 & 0.0 & 0.0 \\
2000IBTC & 20.0 & 0.0 & 0.0 & 0.0 & 20.0 & 0.0 & 0.0 & 0.0 \\
Ikeja Hotel & 0.0 & 0.3 & 0.0 & 0.0 & 0.0 & 0.3 & 0.0 & 0.0 \\
1981/88/040 & 20.0 & 0.0 & 0.0 & 0.0 & 0.0 & 0.0 & 0.0 & 0.0 \\
2002NTEF & 0.0 & 0.0 & 10.0 & 0.0 & 0.0 & 0.0 & 0.0 & 0.0 \\
2001UBA & 11.0 & 0.0 & 0.0 & 0.0 & 0.0 & 0.0 & 0.0 & 0.0 \\
2004UPDC Hotels Ltd & & & & & & & & $\mathbf{6 . 0}$ \\
& $\mathbf{1 4 2 . 8}$ & $\mathbf{9 . 6}$ & $\mathbf{2 1 . 3}$ & $\mathbf{1 5 . 0}$ & $\mathbf{6 3 . 6}$ & $\mathbf{7 . 5}$ & $\mathbf{6 . 8}$ & $\mathbf{6 . 9}$
\end{tabular}

Approval Pending Effectiveness

\begin{tabular}{lrrrr} 
& Loan & Equity & Quasi & Partic. \\
\cline { 2 - 5 } 2005Zenith Bank & 30.0 & 6.0 & 4.0 & 0.0 \\
Total Pending Commitment: & $\mathbf{3 0 . 0}$ & $\mathbf{6 . 0}$ & $\mathbf{4 . 0}$ & $\mathbf{0 . 0}$
\end{tabular}


Nigeria: IDA Lending Summary FY04-FY07

As of Date: October 7, 2004

\begin{tabular}{|c|c|c|c|c|}
\hline Fiscal year & Project ID & $U S \$(M)$ & $\begin{array}{c}\text { Strategic Rewards b } \\
(\mathrm{H} / \mathrm{M} / \mathrm{L})\end{array}$ & $\begin{array}{c}\text { Implementation b } \\
\text { Risks }(H / M / L)\end{array}$ \\
\hline \multirow[t]{7}{*}{2005} & Economic Reform and Governance & 100.0 & $\mathrm{H}$ & $\mathrm{H}$ \\
\hline & Urban Youth Employment \& Empowerment & 300.0 & $\mathrm{H}$ & $\mathrm{H}$ \\
\hline & Niger-Delta Development & 25.0 & $\mathrm{H}$ & $\mathrm{H}$ \\
\hline & State Governance and Capacity Building & 100.0 & $\mathrm{H}$ & $\mathrm{H}$ \\
\hline & Supplemental Polio Eradication & 22.0 & $\mathrm{H}$ & $\mathrm{M}$ \\
\hline & Sustainable Management Mineral Resources & 120.0 & M & M \\
\hline & Result & 667.0 & & \\
\hline \multirow[t]{7}{*}{2006} & Adult Civic Education \& Empowerment & 27.0 & $\mathrm{H}$ & M \\
\hline & Lagos Metropolitan Dev Private & 60.0 & $\mathrm{H}$ & $\mathrm{H}$ \\
\hline & Lagos Water Sector Restructuring & 100.0 & M & M \\
\hline & Rural Access \& Mobility & 100.0 & $\mathrm{H}$ & $\mathrm{H}$ \\
\hline & Private Provision of Rural Infrastructure & 70.0 & $\mathrm{H}$ & M \\
\hline & National Electricity Development & 200.0 & $\mathrm{H}$ & $\mathrm{H}$ \\
\hline & Result & 557.0 & & \\
\hline \multirow[t]{6}{*}{2007} & Health Systems III & 100.0 & $\mathrm{H}$ & M \\
\hline & Fadama III & 30.0 & $\mathrm{H}$ & $\mathrm{H}$ \\
\hline & Community -based Poverty Reduction II & 0.2 & $\mathrm{H}$ & M \\
\hline & Federal Roads Development & 100.0 & $\mathrm{H}$ & $\mathrm{H}$ \\
\hline & Universal Basic Education II & 100.0 & $\mathrm{H}$ & M \\
\hline & Result & 330.2 & & \\
\hline Overall Res & & $1,554.2$ & & \\
\hline
\end{tabular}




\section{Nigeria: Summary of Non-lending Services}

\begin{tabular}{|c|c|}
\hline Product & $\begin{array}{c}\text { Completion } \\
\text { Fiscal Year }(F Y)\end{array}$ \\
\hline \multicolumn{2}{|l|}{ Recent completions } \\
\hline Social Risk Assessment & FY02 \\
\hline Private Sector Assessment & FY02 \\
\hline States Public Finances Study & FY03 \\
\hline Environment/Poverty & FY03 \\
\hline Strategic Conflict Assessment & FY03 \\
\hline Service Delivery Survey & FY04 \\
\hline Macro \& Growth & FY04 \\
\hline Education CSR & FY04 \\
\hline Lagos SPAR & FY04 \\
\hline Lagos CFAR & FY04 \\
\hline Pensions Reform Dialogue & FY04 \\
\hline Risk and Vulnerability & FY04 \\
\hline Anticorruption & FY04 \\
\hline Country Portfolio Performance Review (CPPR) & FY04 \\
\hline Sub-national Debt Management & FY04 \\
\hline Power Sector Policy & FY04 \\
\hline EFA Preparation Support Strategy & FY04 \\
\hline \multicolumn{2}{|l|}{ Underway } \\
\hline Country Gender Assessment & FY05 \\
\hline Basic Agricultural Services & FY05 \\
\hline Oil Revenues Management & FY05 \\
\hline Health CSR & FY05 \\
\hline Lagos Strategy for Eco. Dev \& Poverty Reduction & FY05 \\
\hline PFMU Support & FY05 \\
\hline Country Portfolio Performance Review (CPPR) & FY05 \\
\hline CEM on Diversification, Sources of Growth & FY05 \\
\hline Debt Management & FY05 \\
\hline Telecom TA & FY05 \\
\hline \multicolumn{2}{|l|}{ Planned } \\
\hline Poverty Assessment & FY05/06 \\
\hline Agriculture Sector Review & FY06 \\
\hline EITI Management/Gas and Oil Sector Policy & FY05/06/07 \\
\hline Communications and Outreach & FY05/06/07 \\
\hline
\end{tabular}




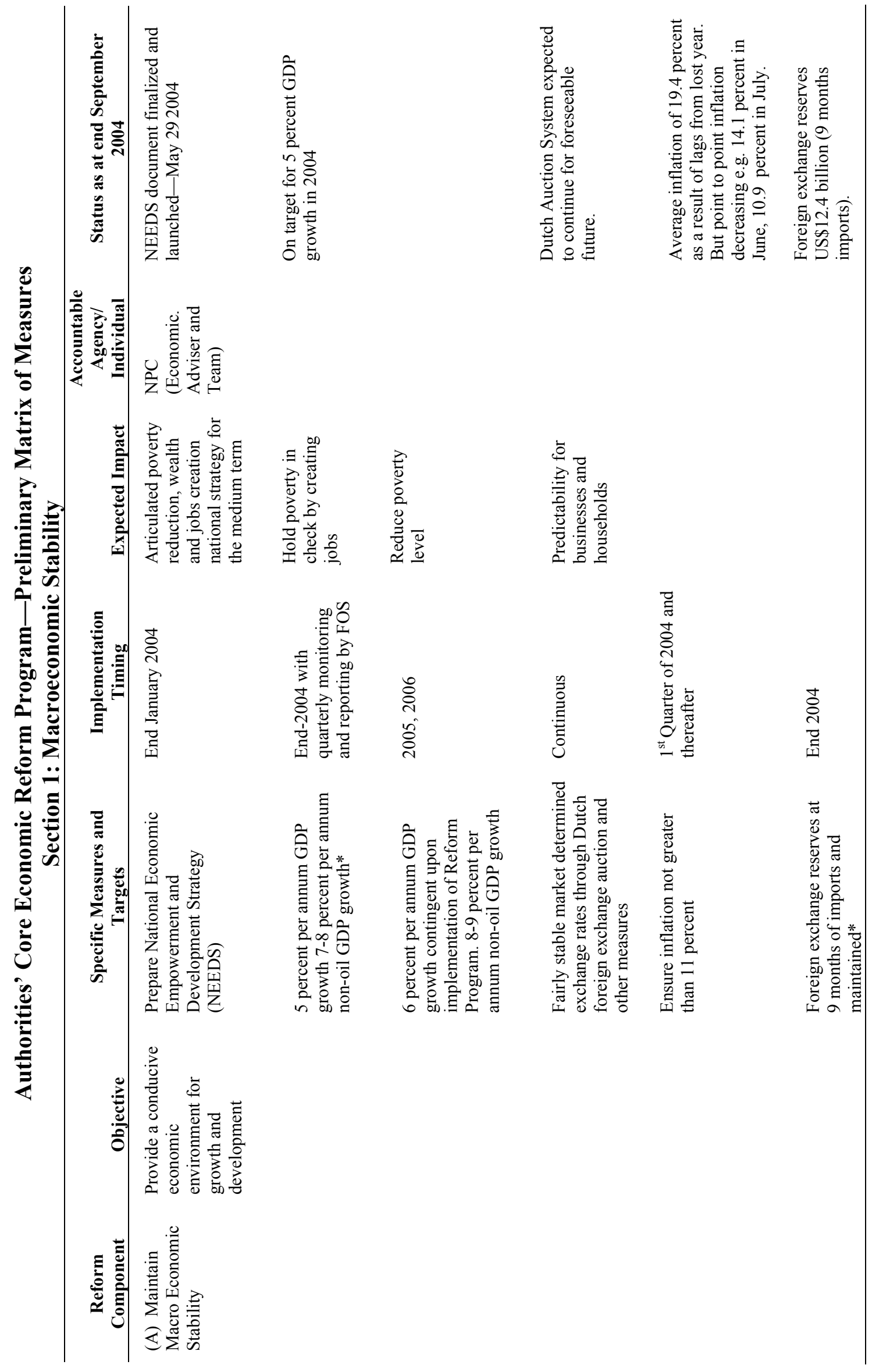




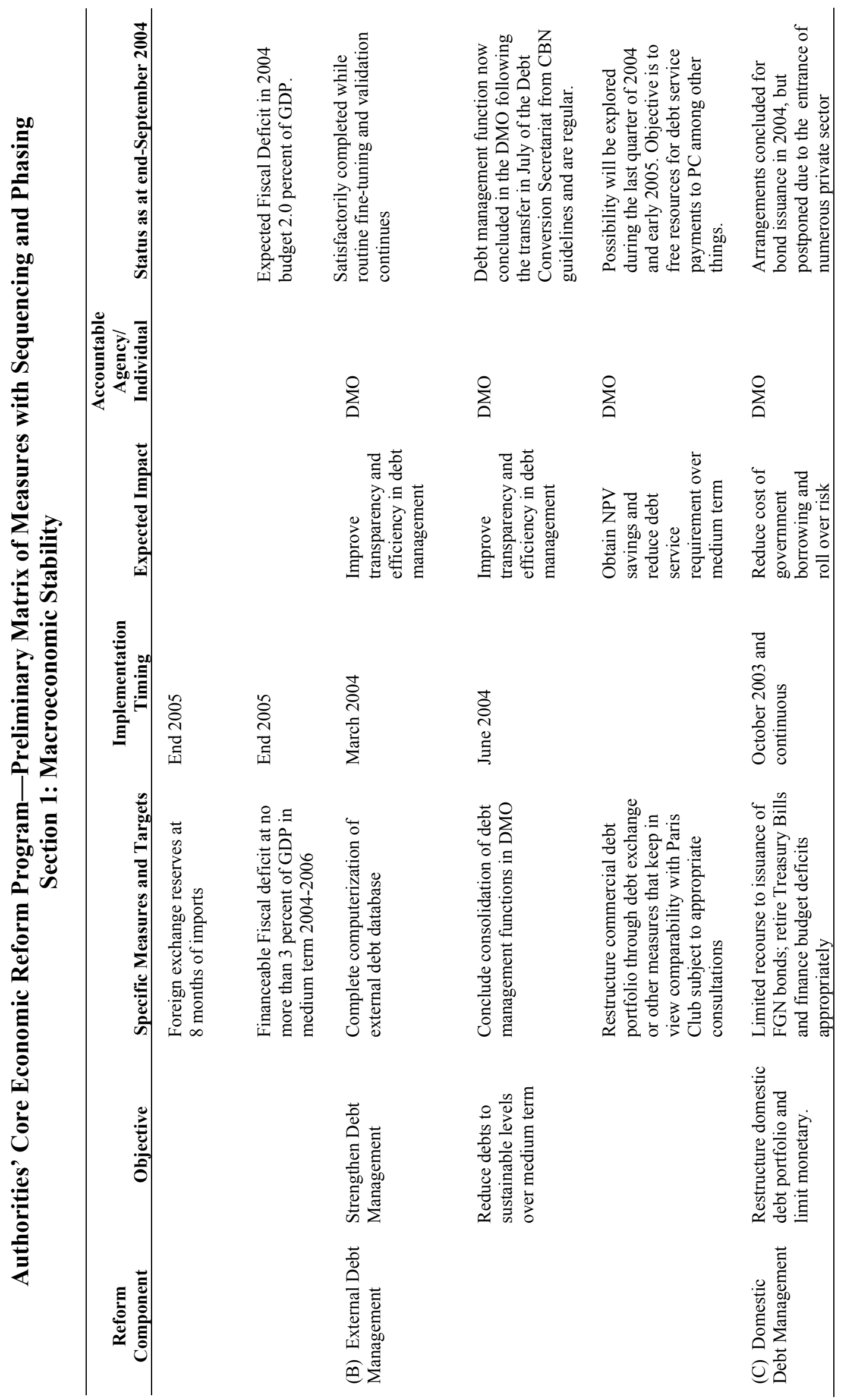




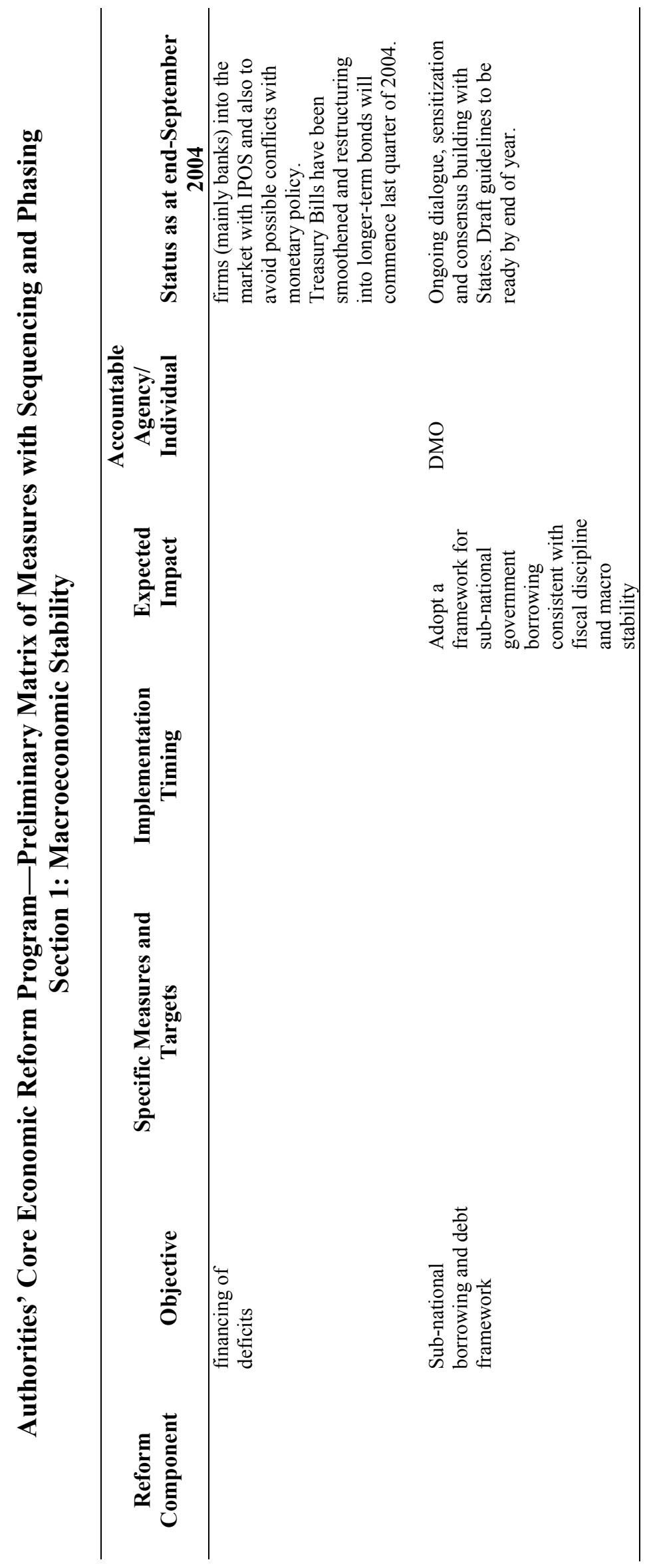




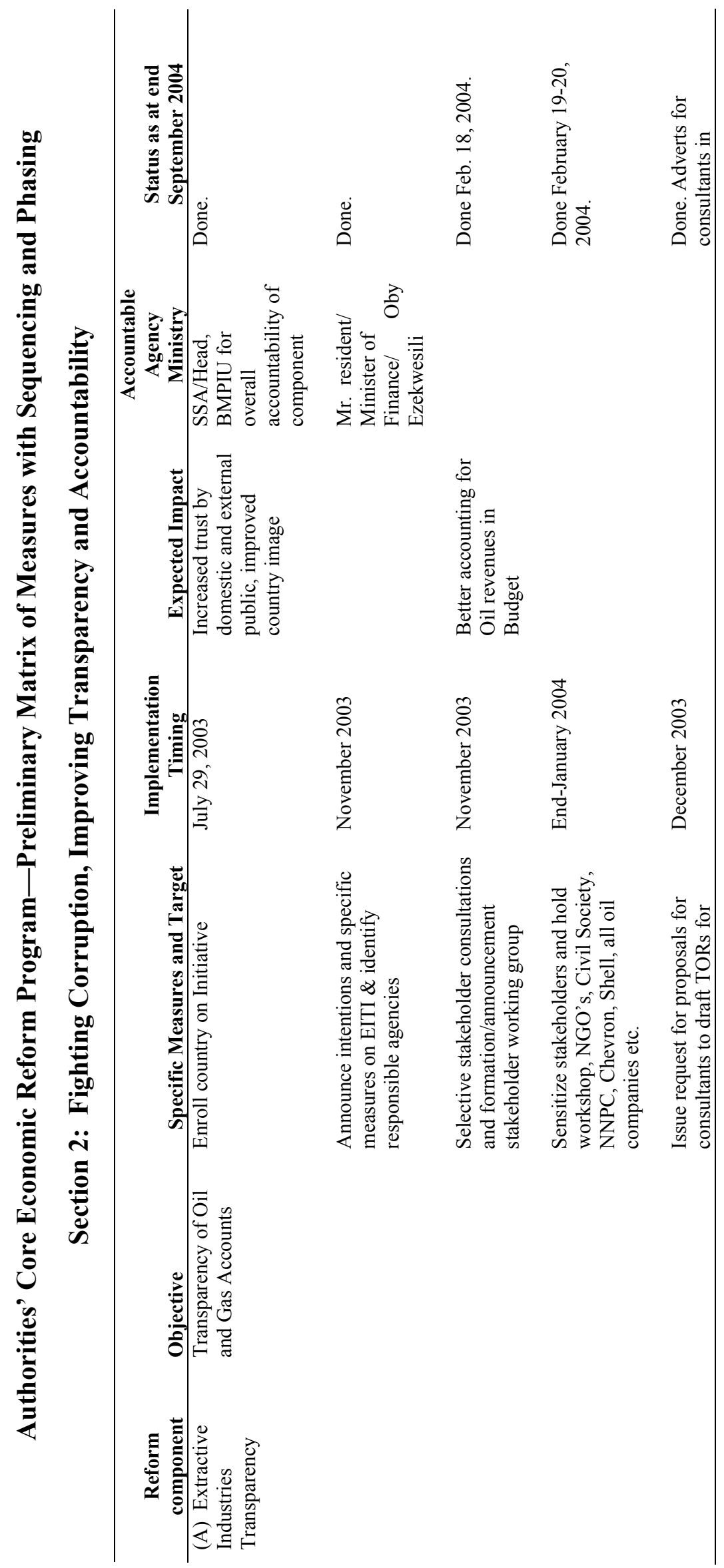




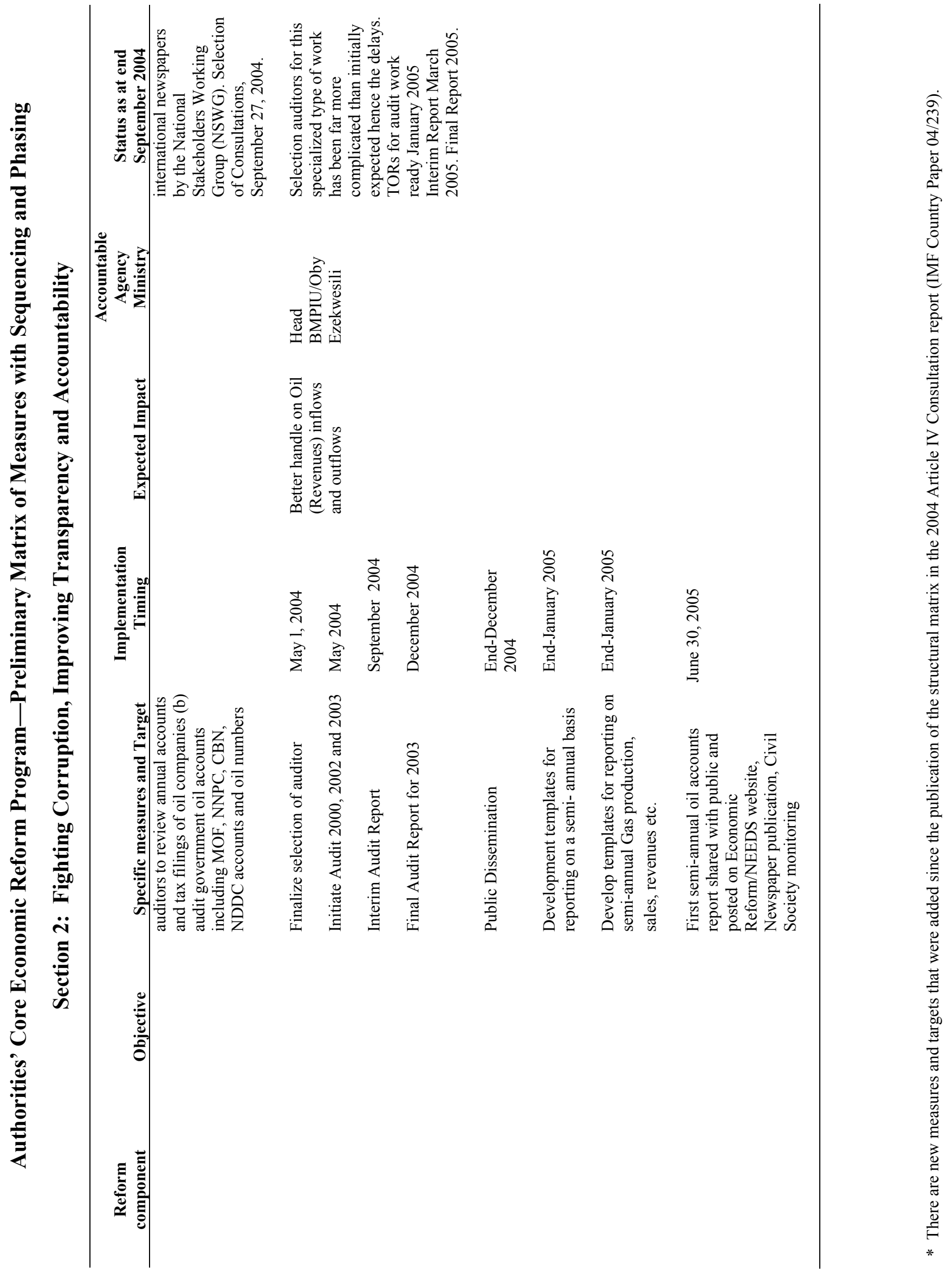




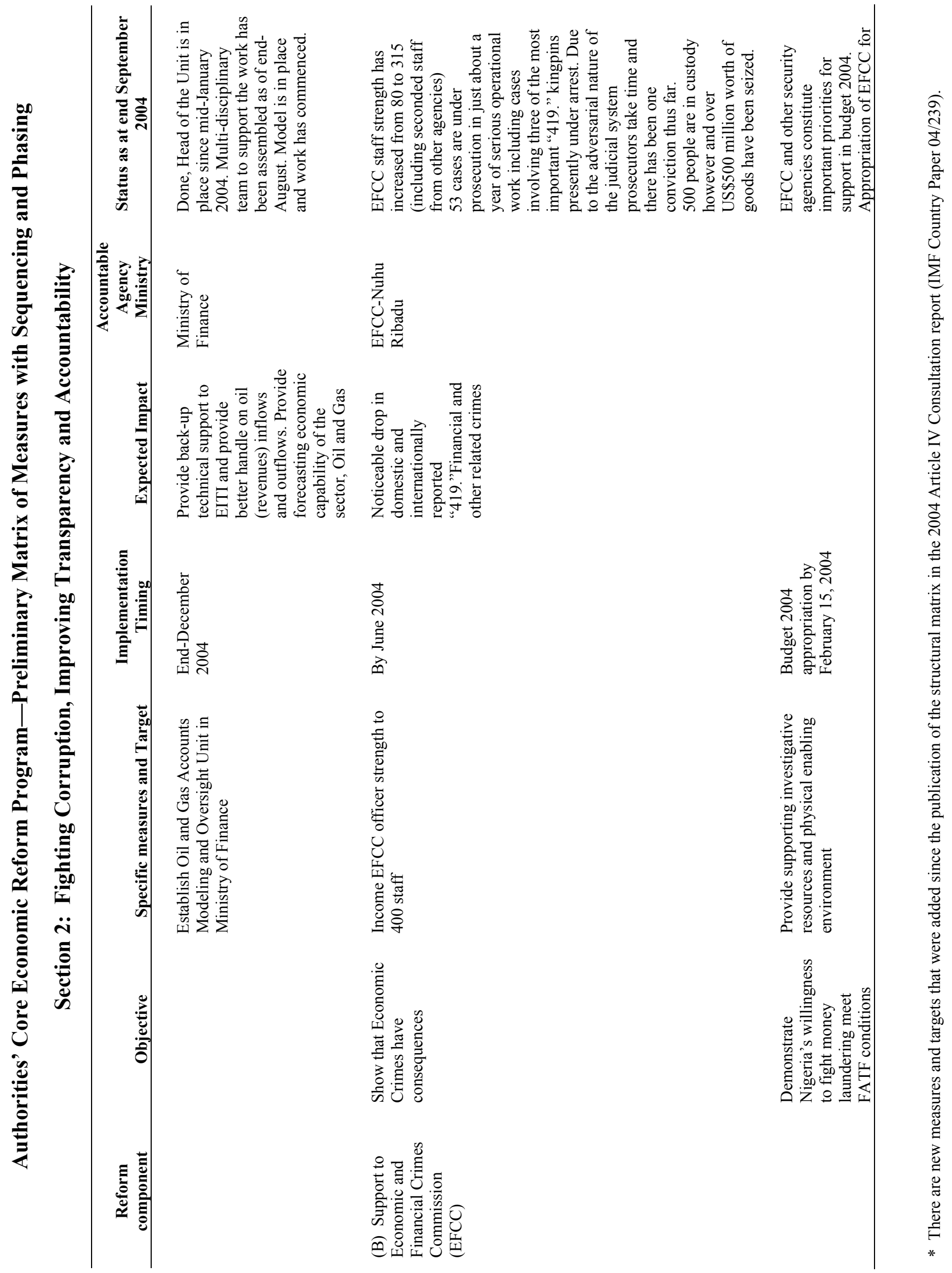




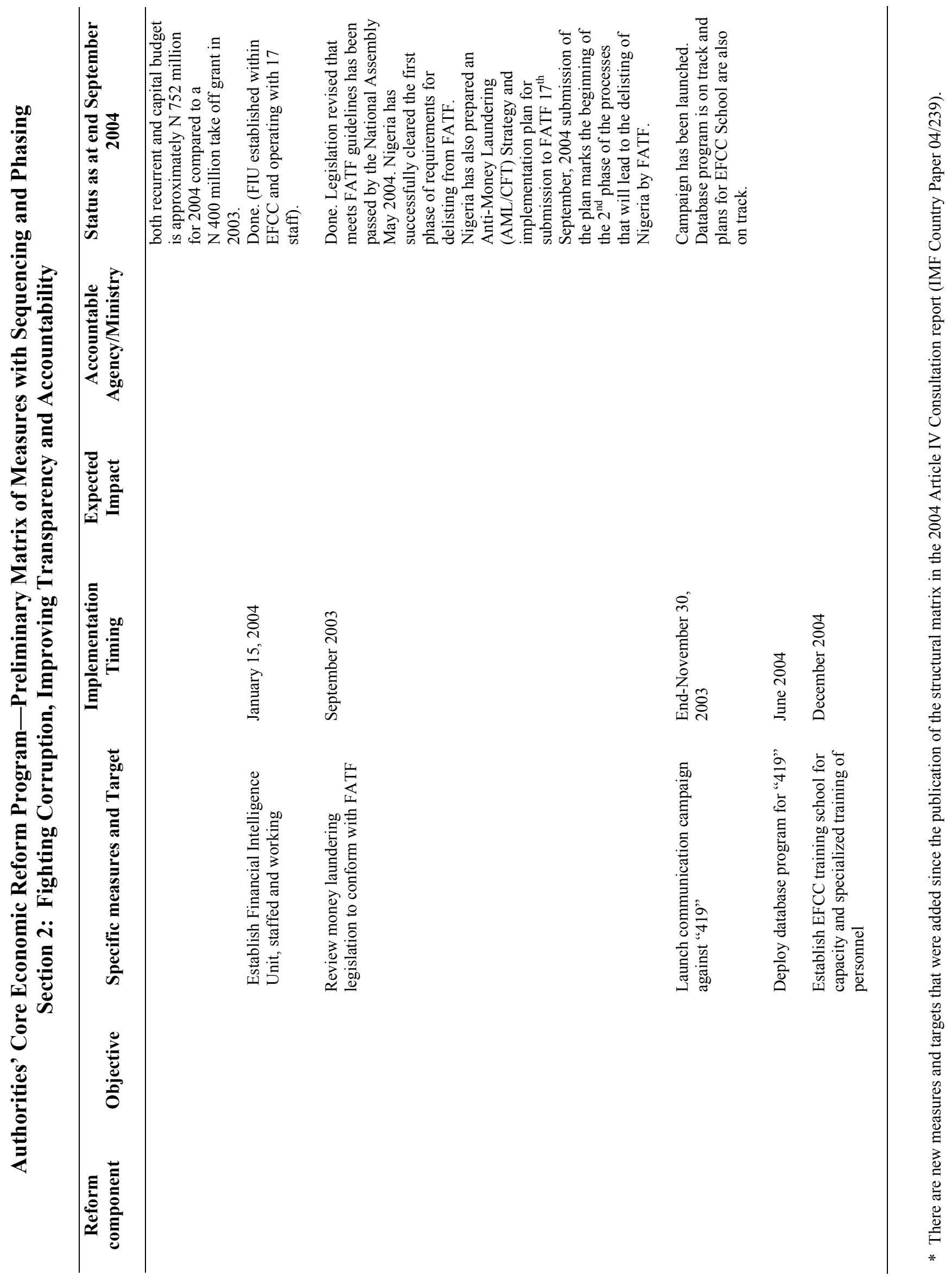




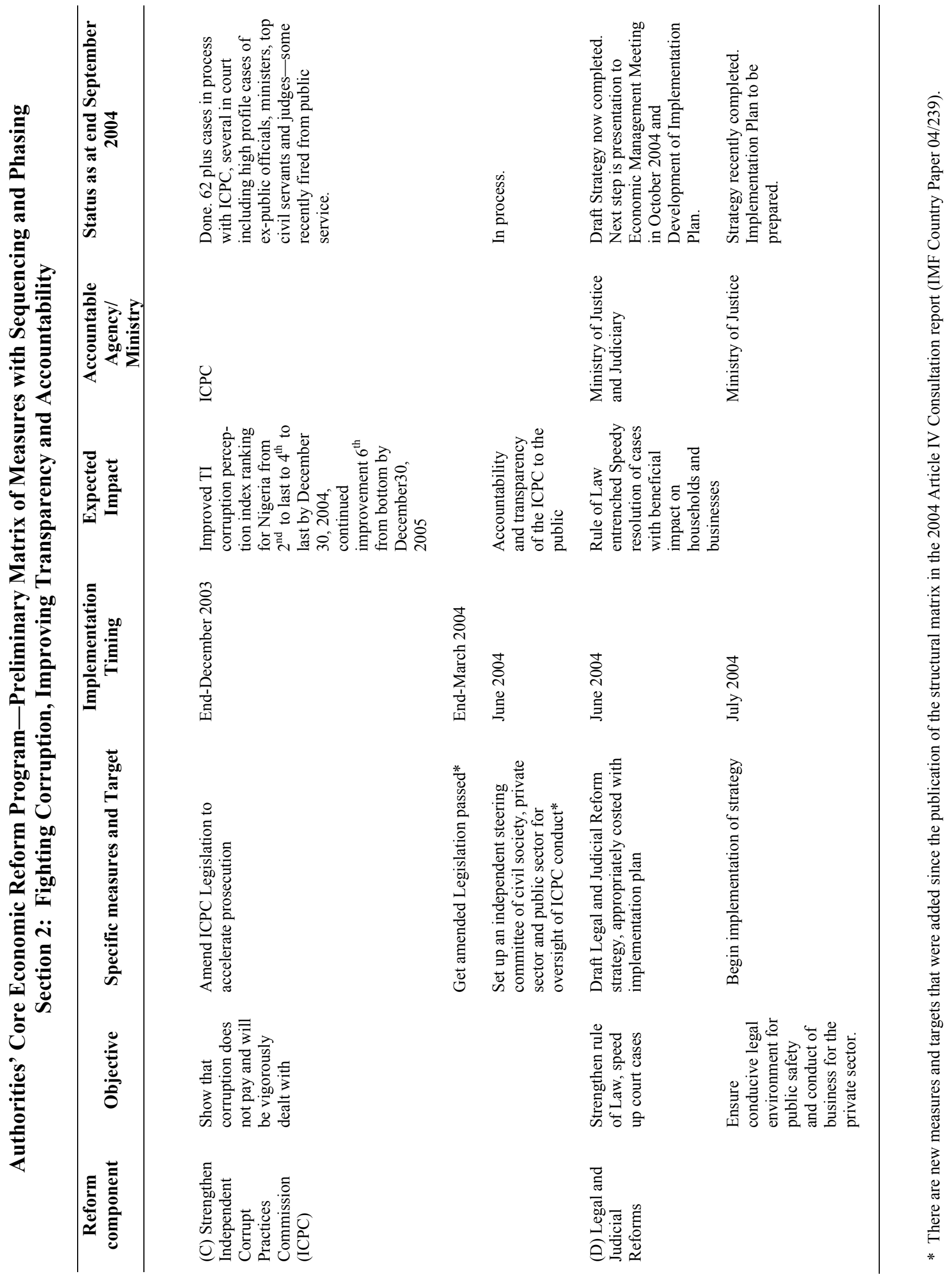




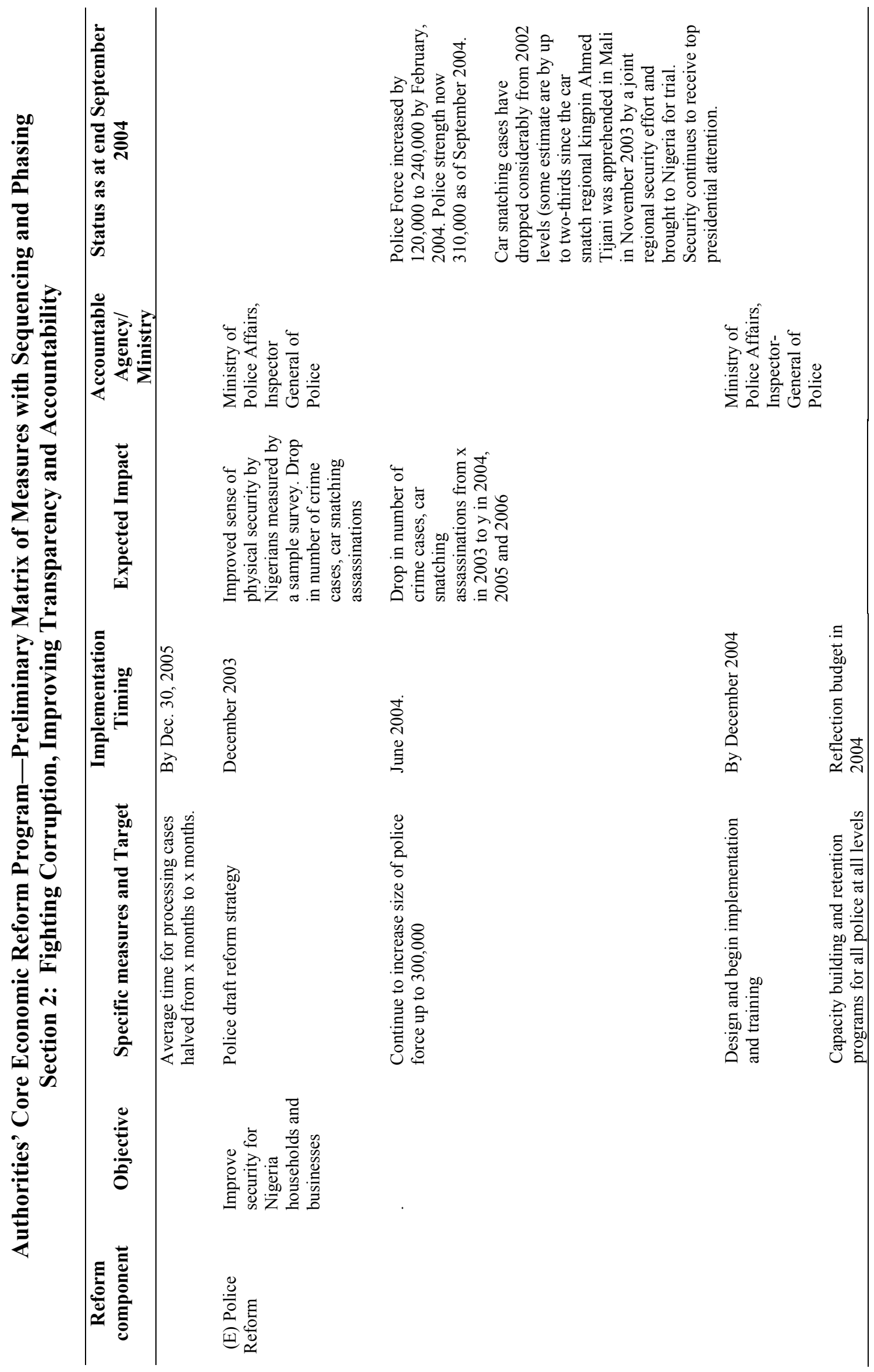




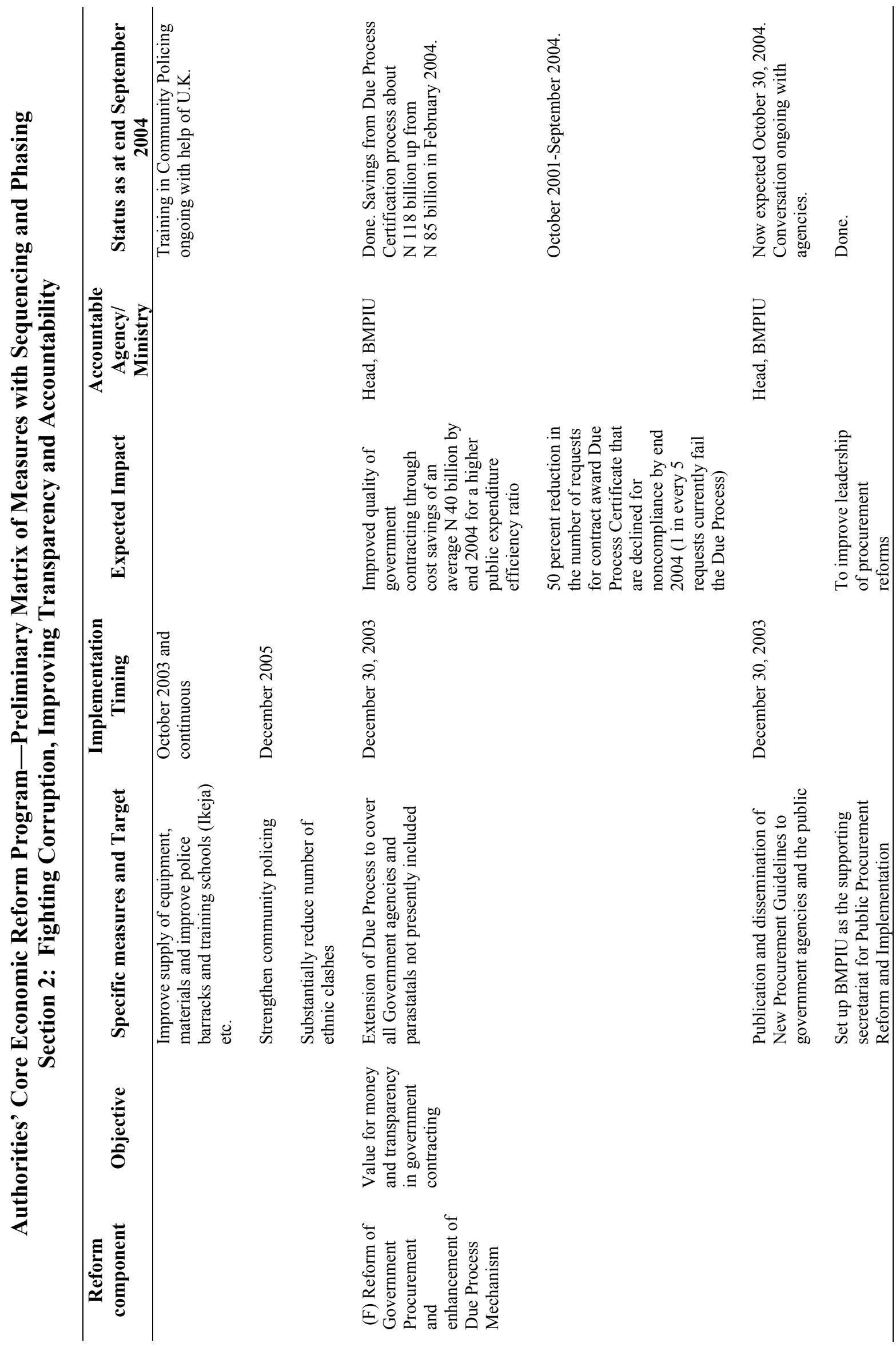




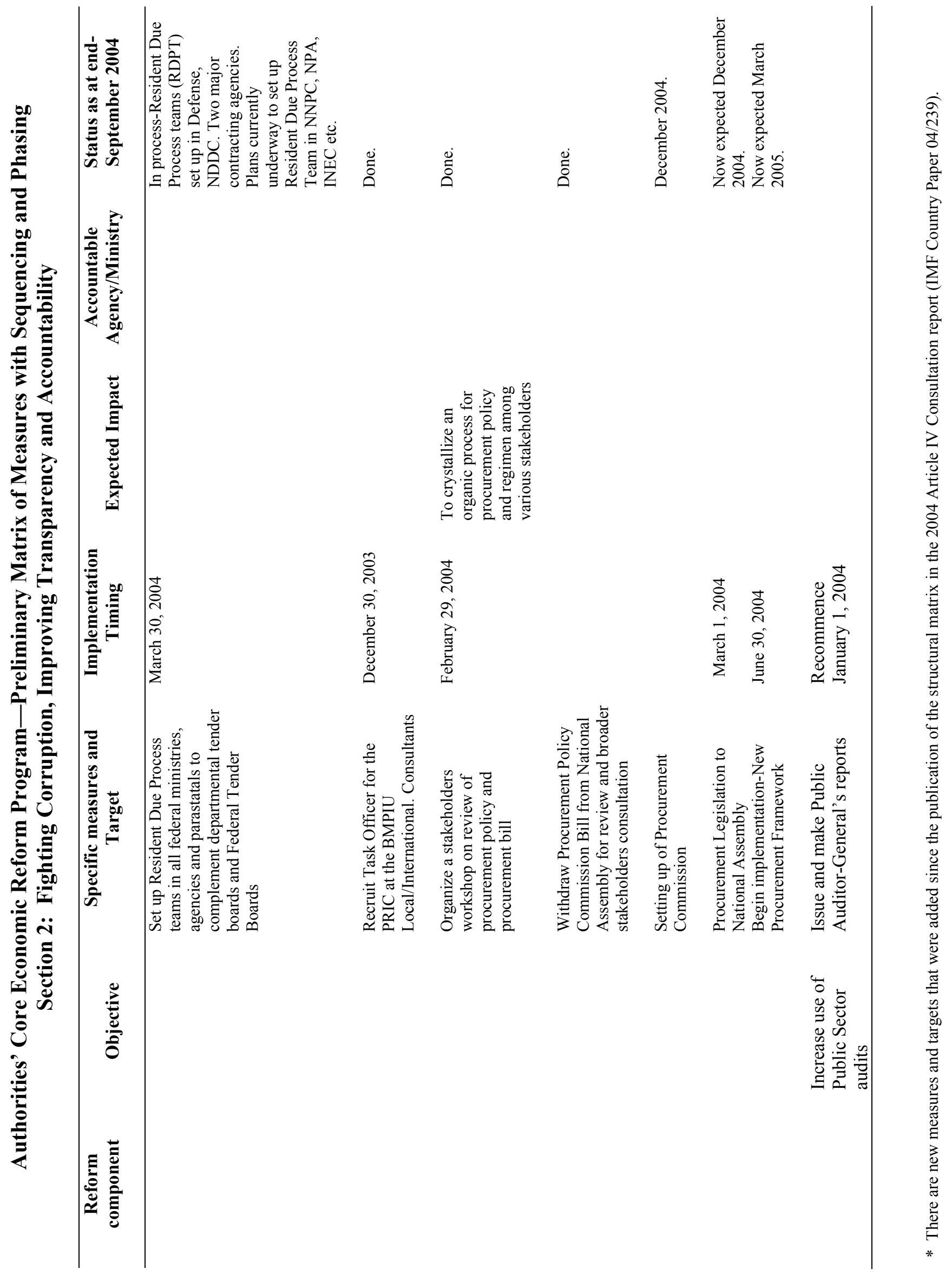




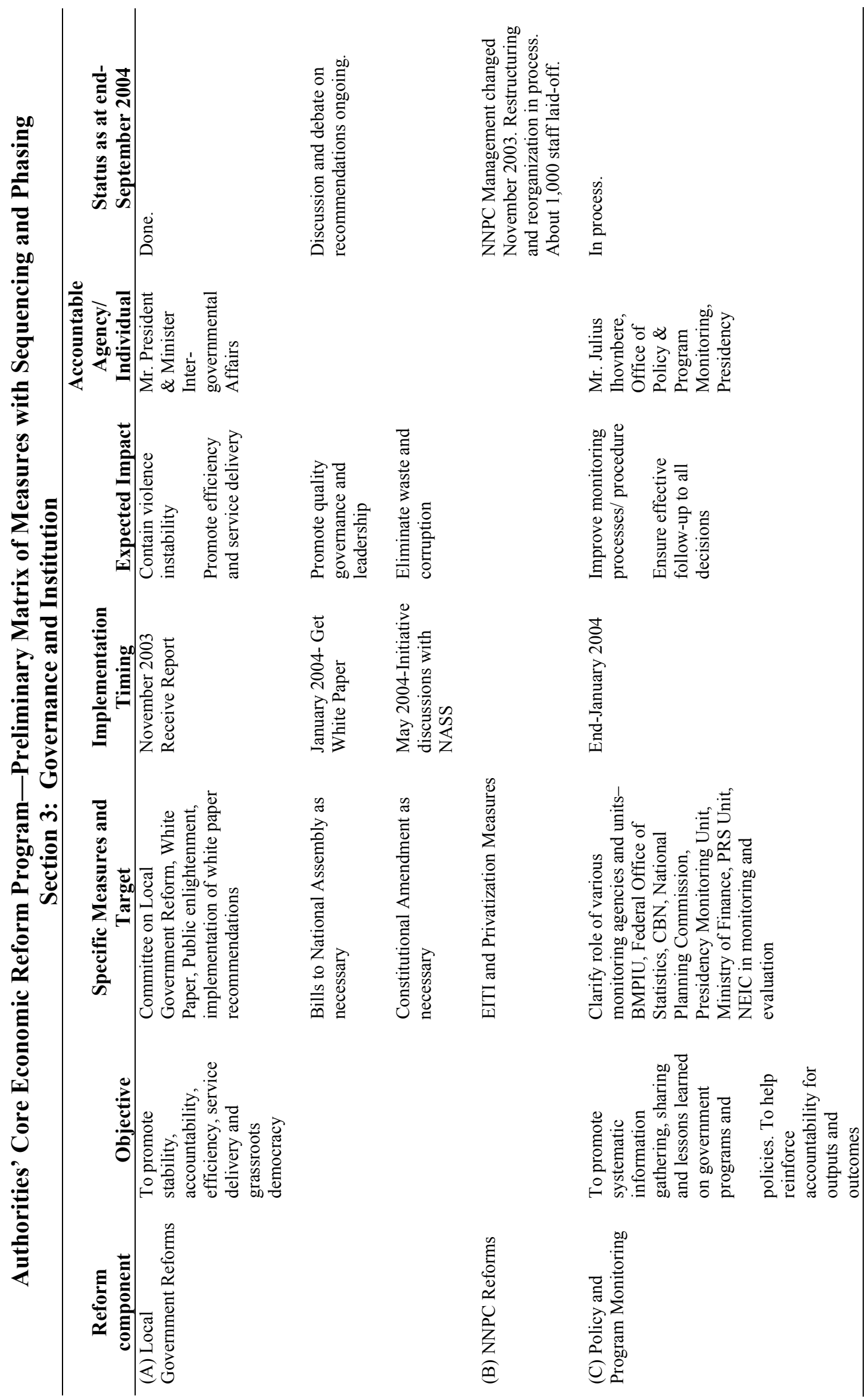




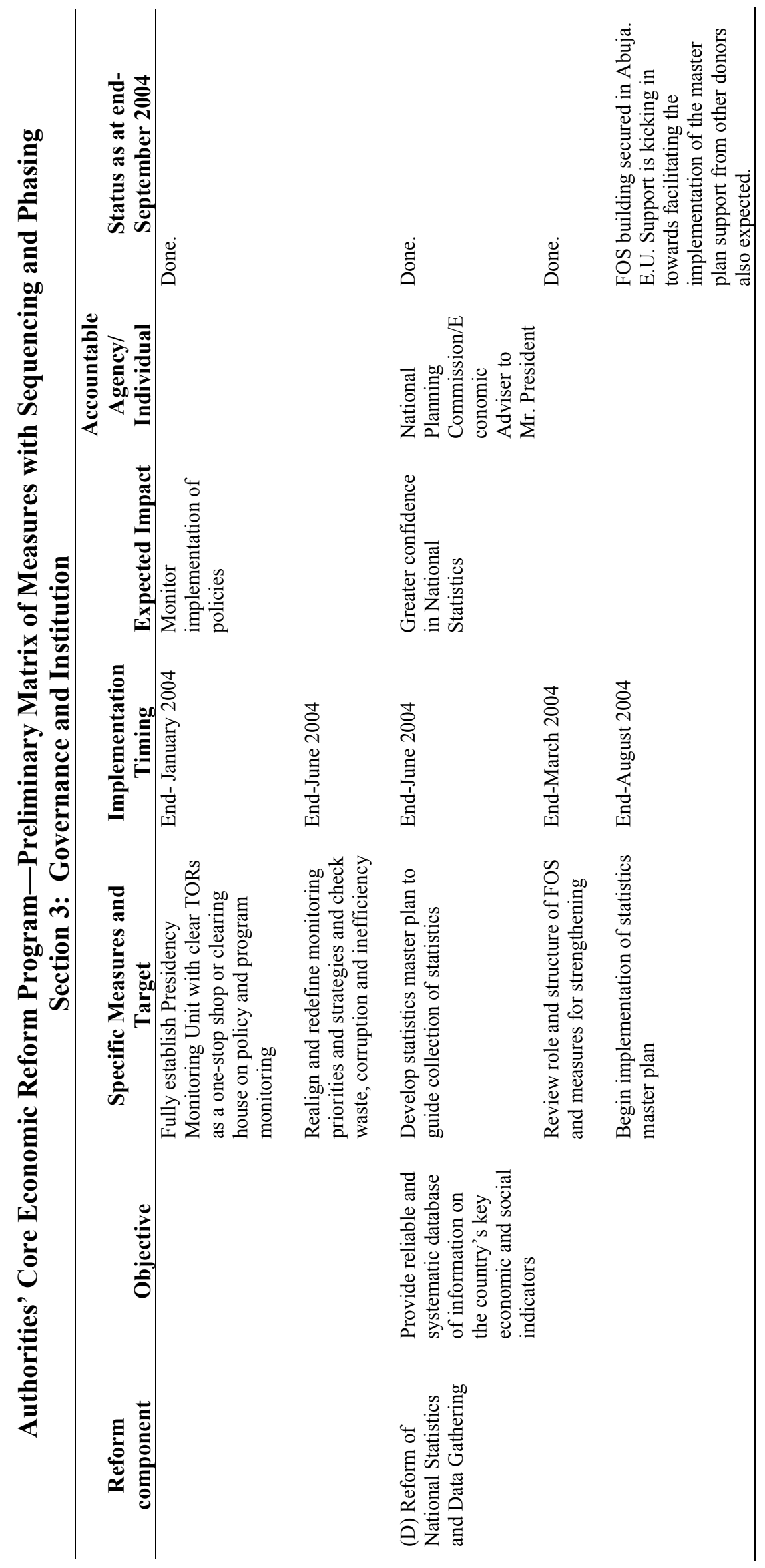




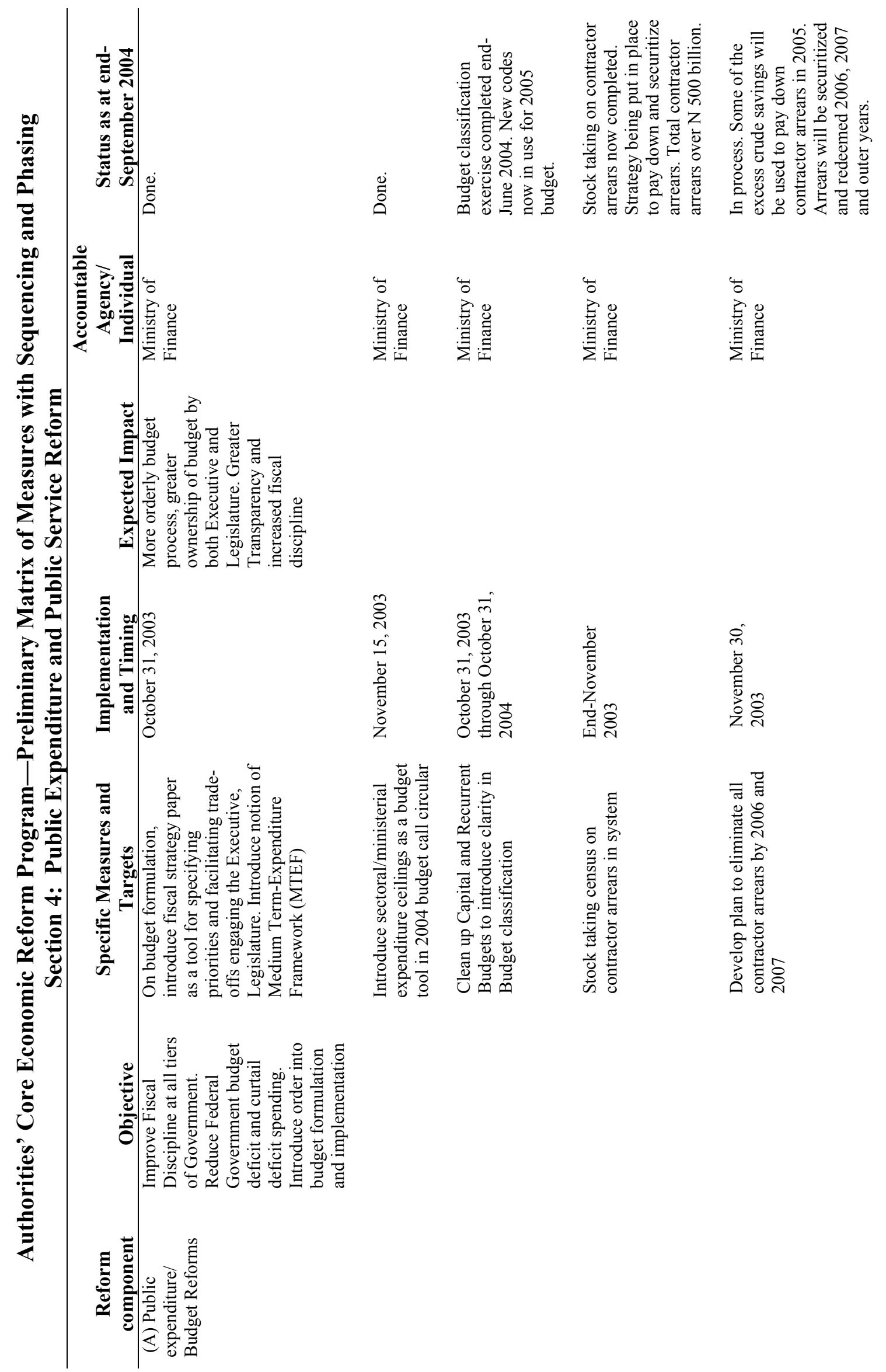




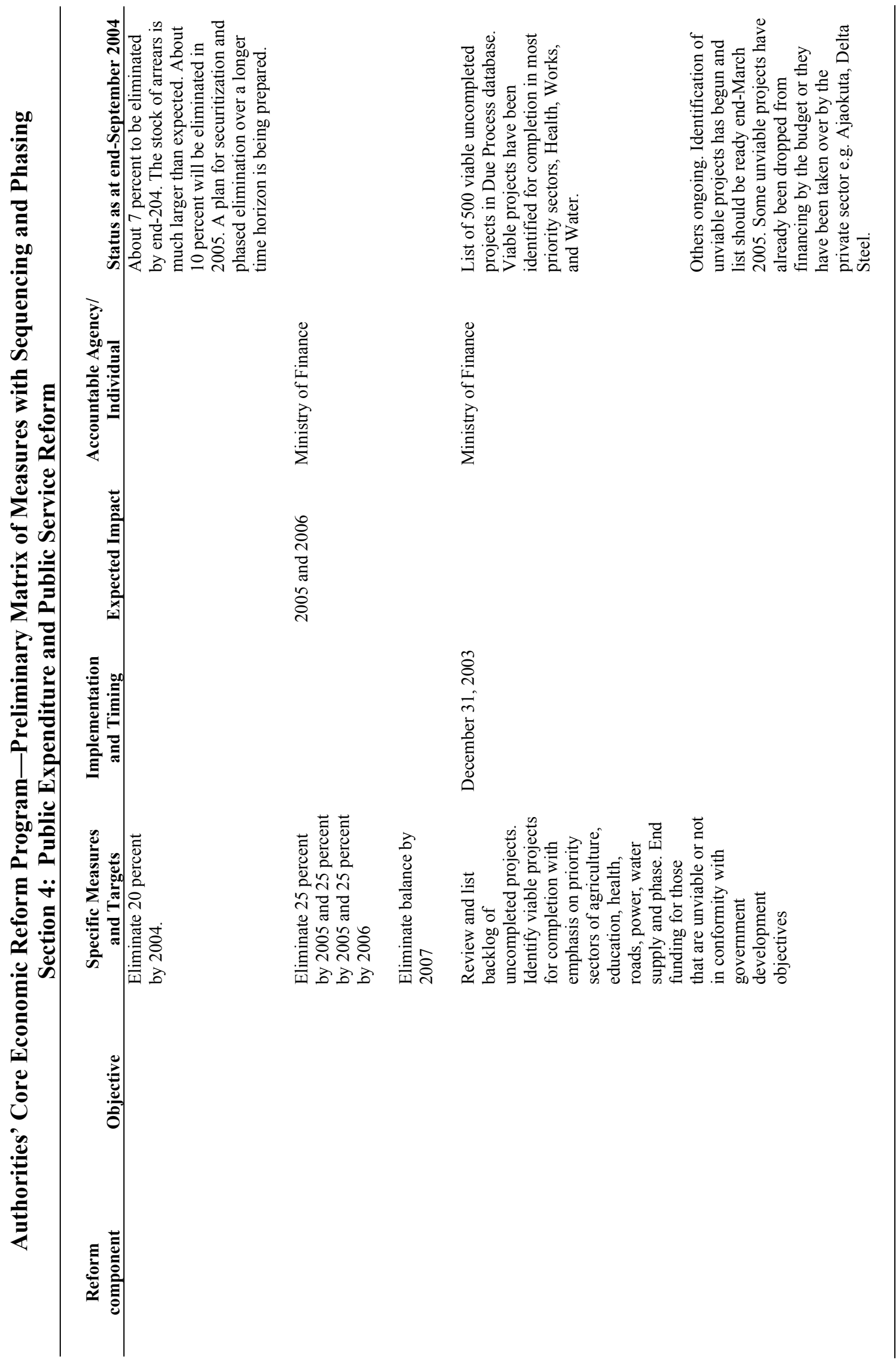




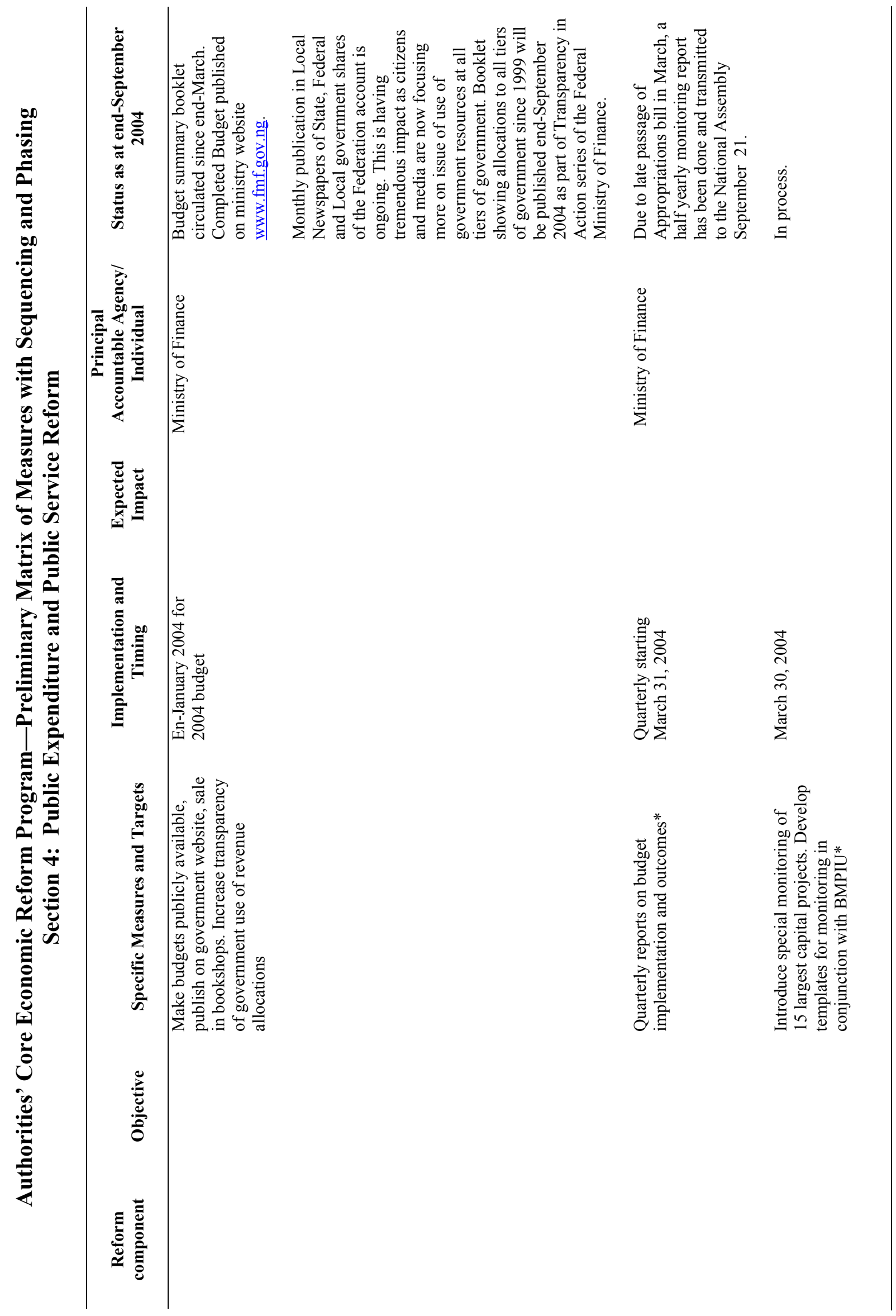




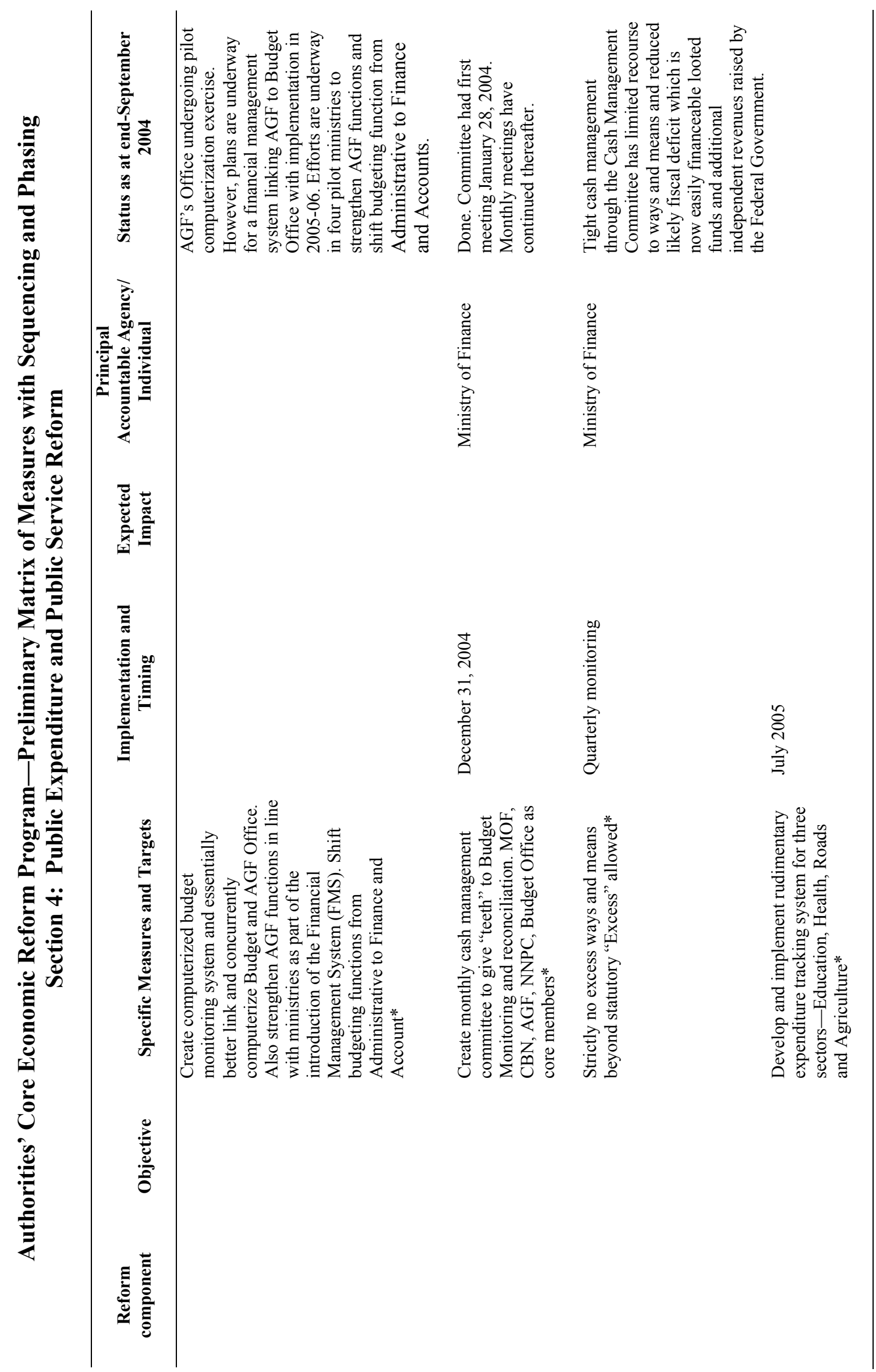




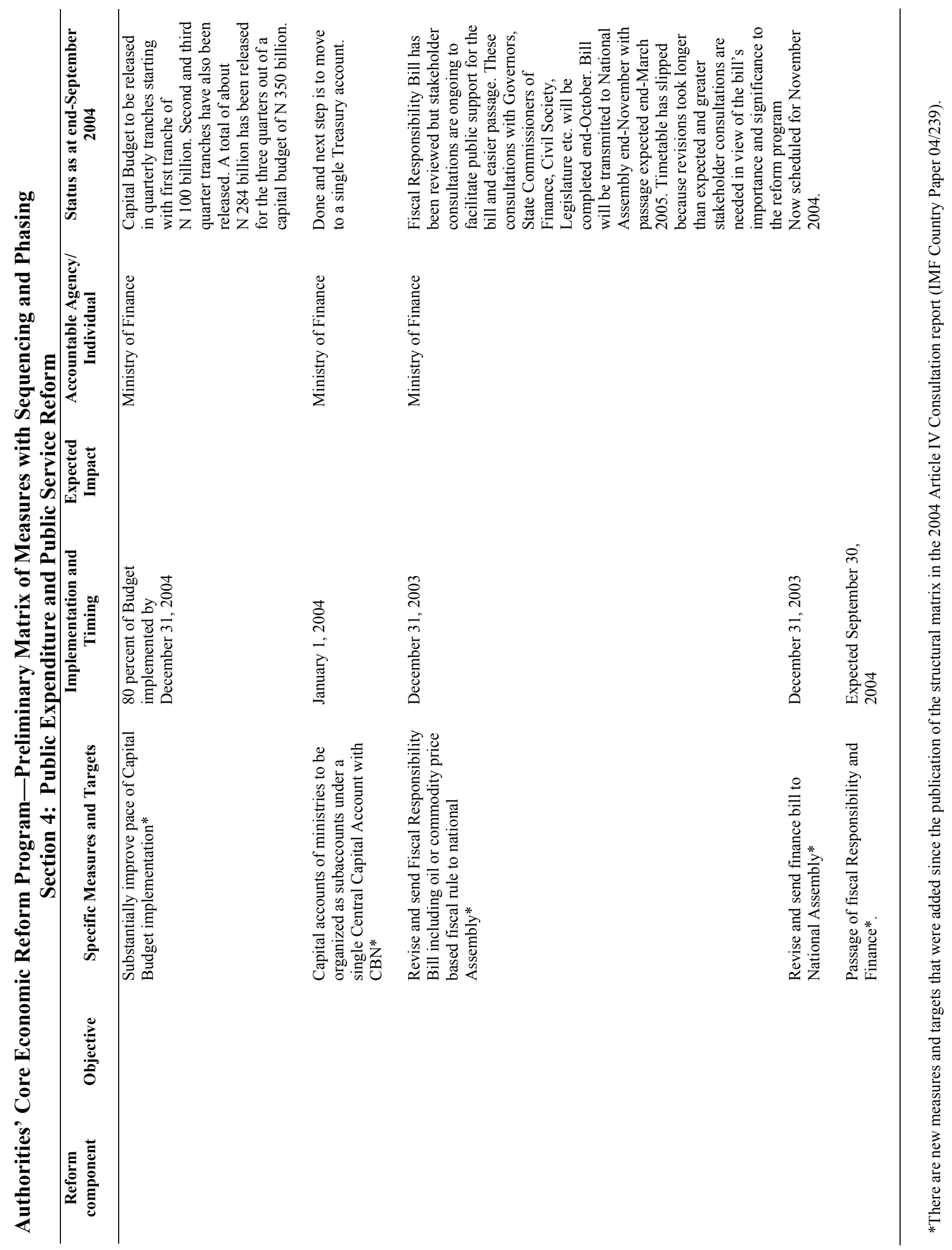




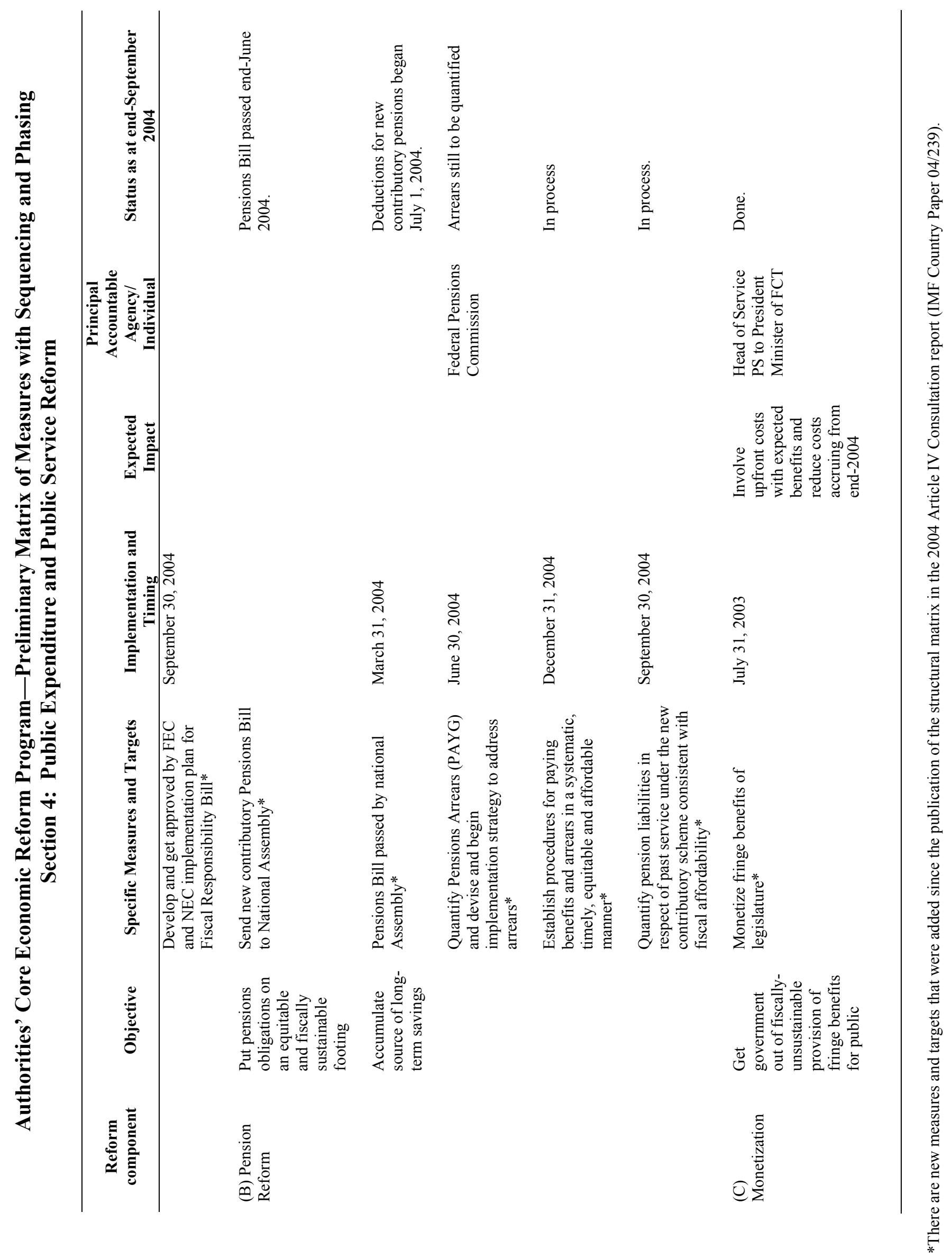




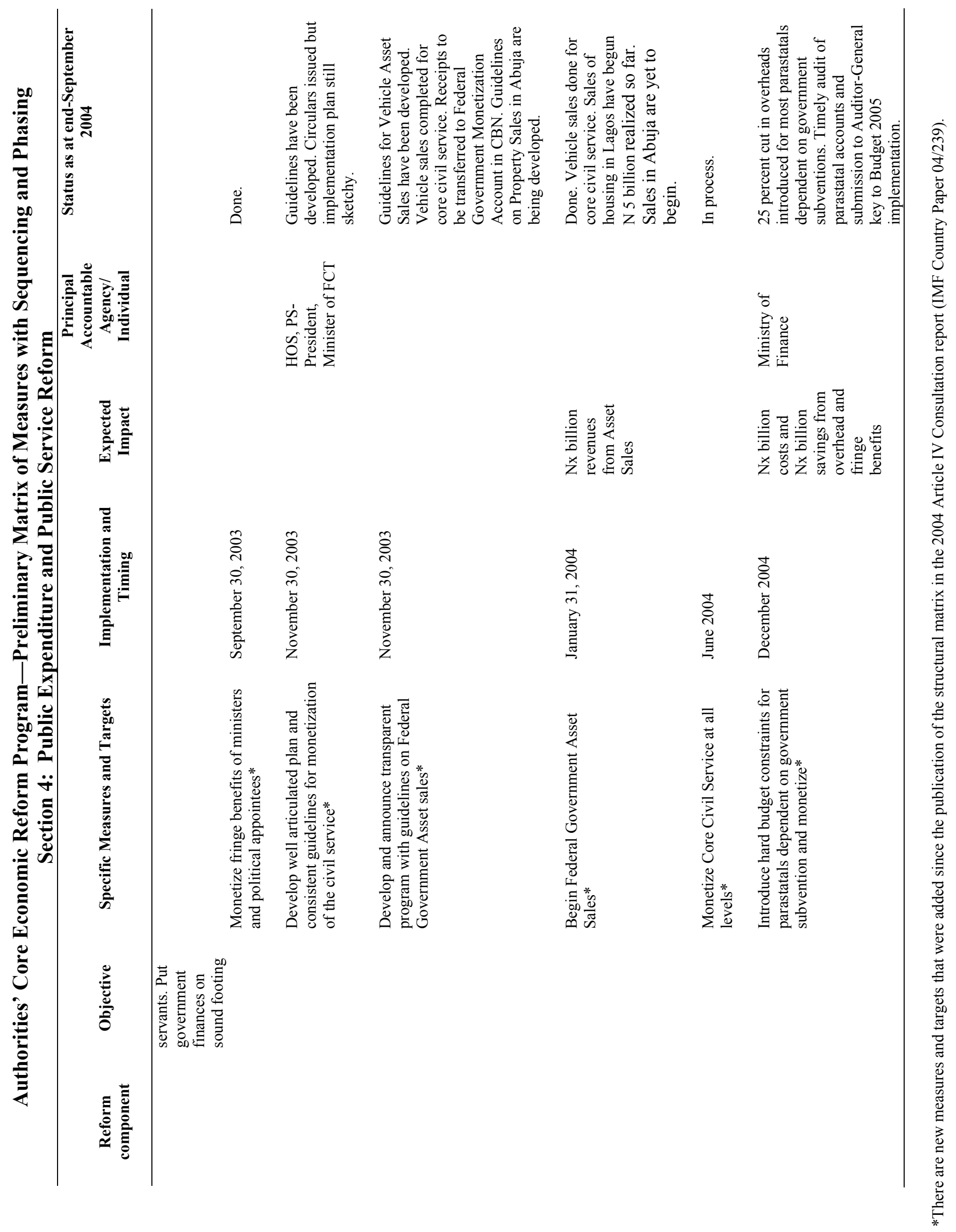




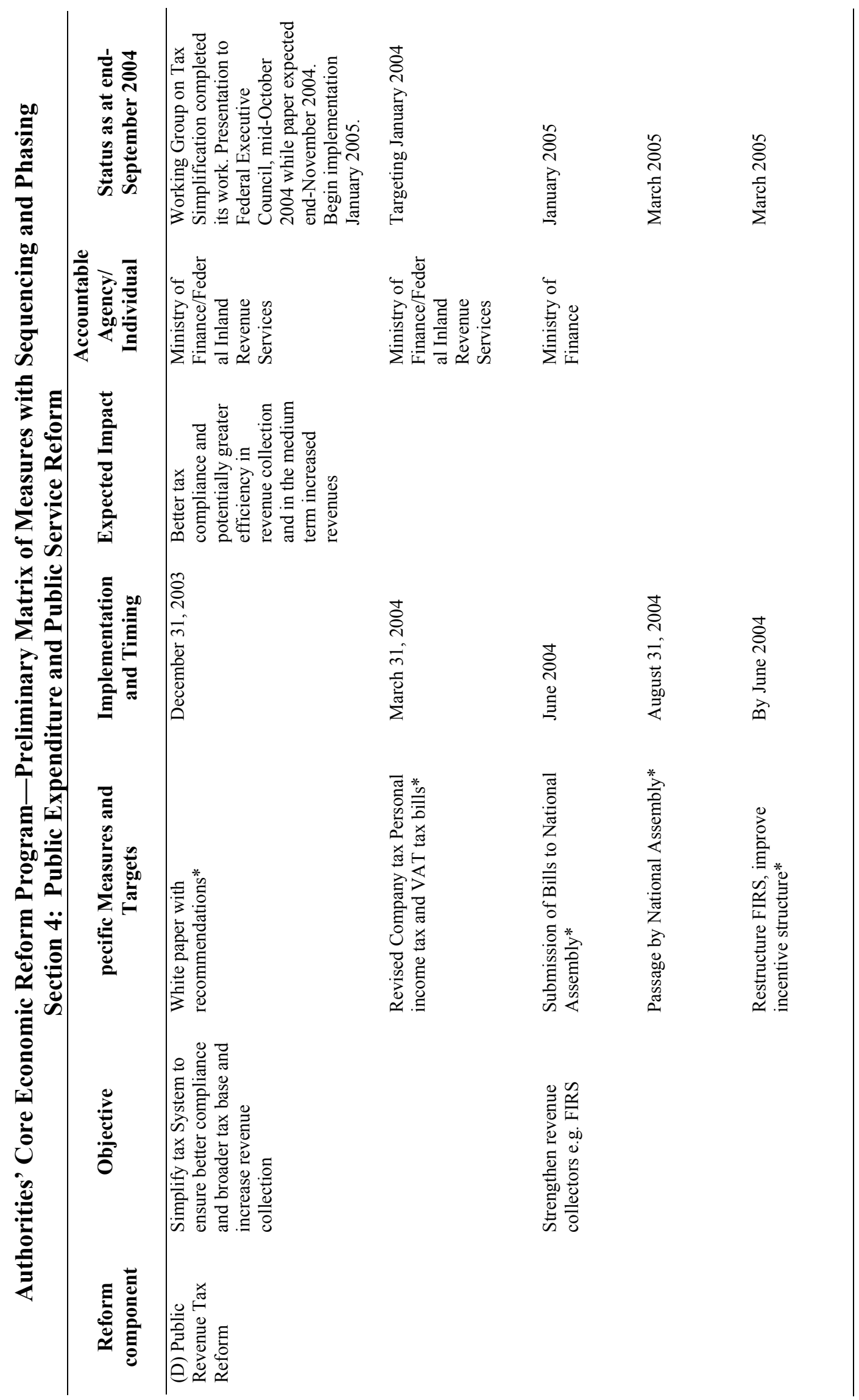



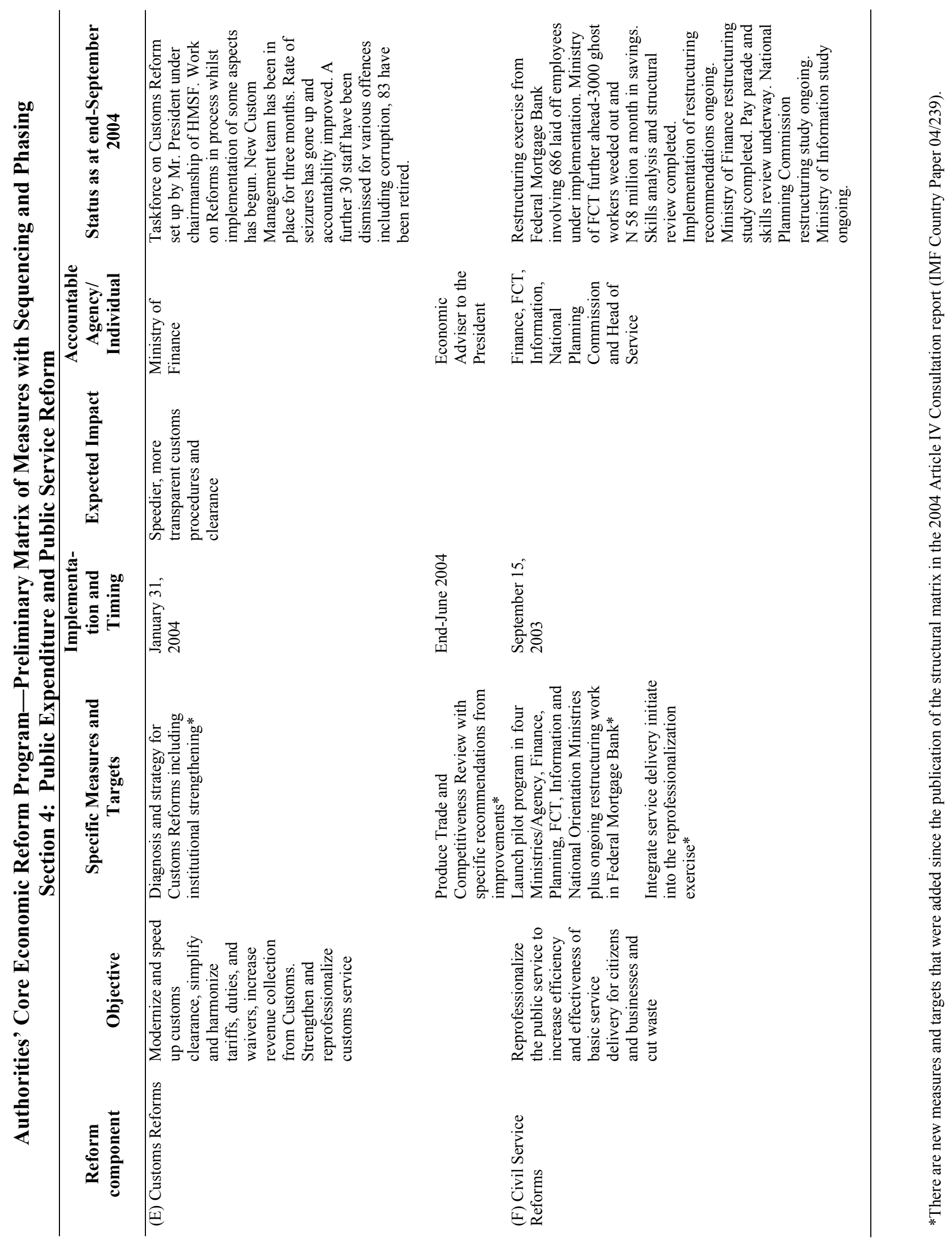


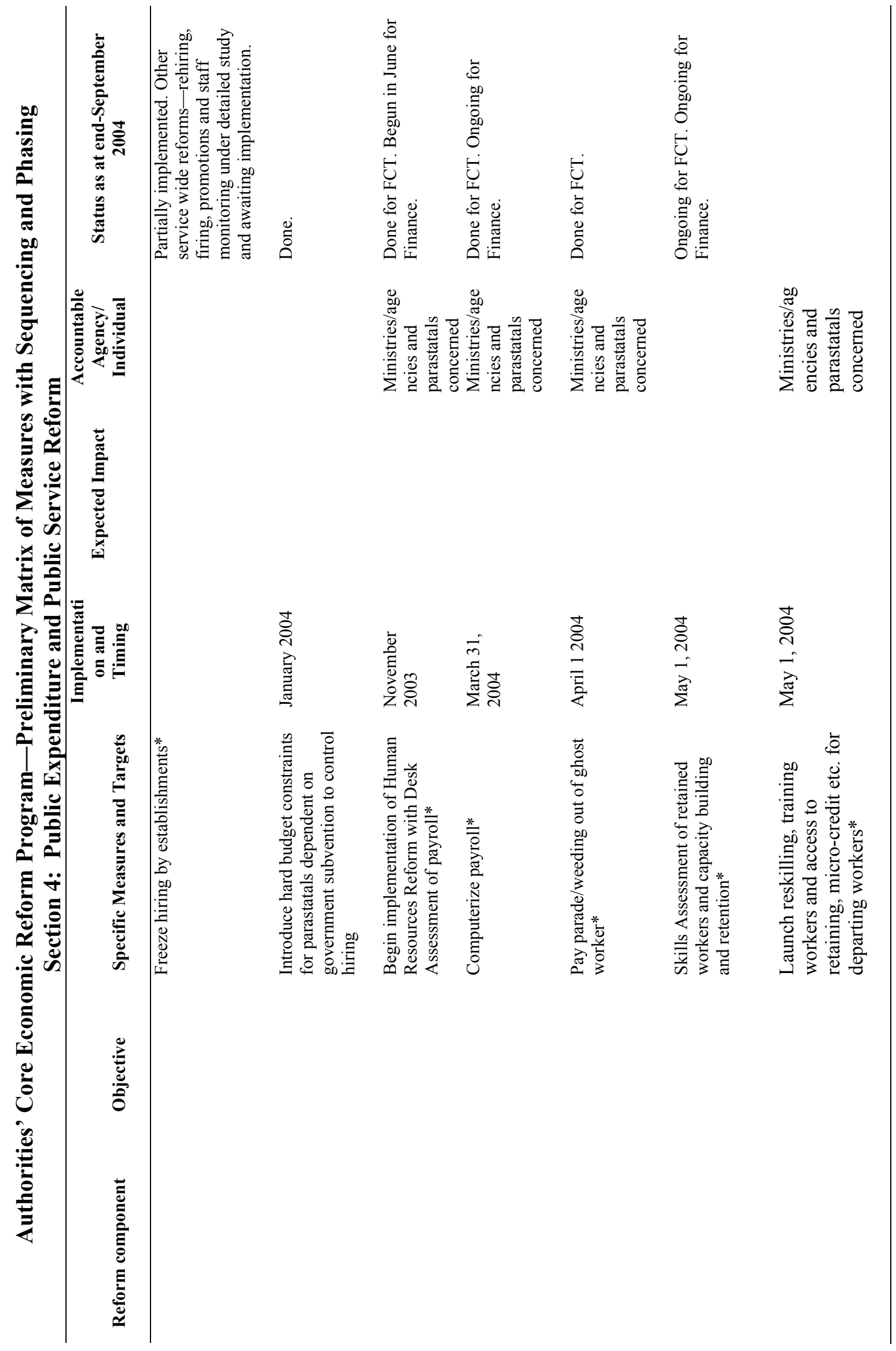




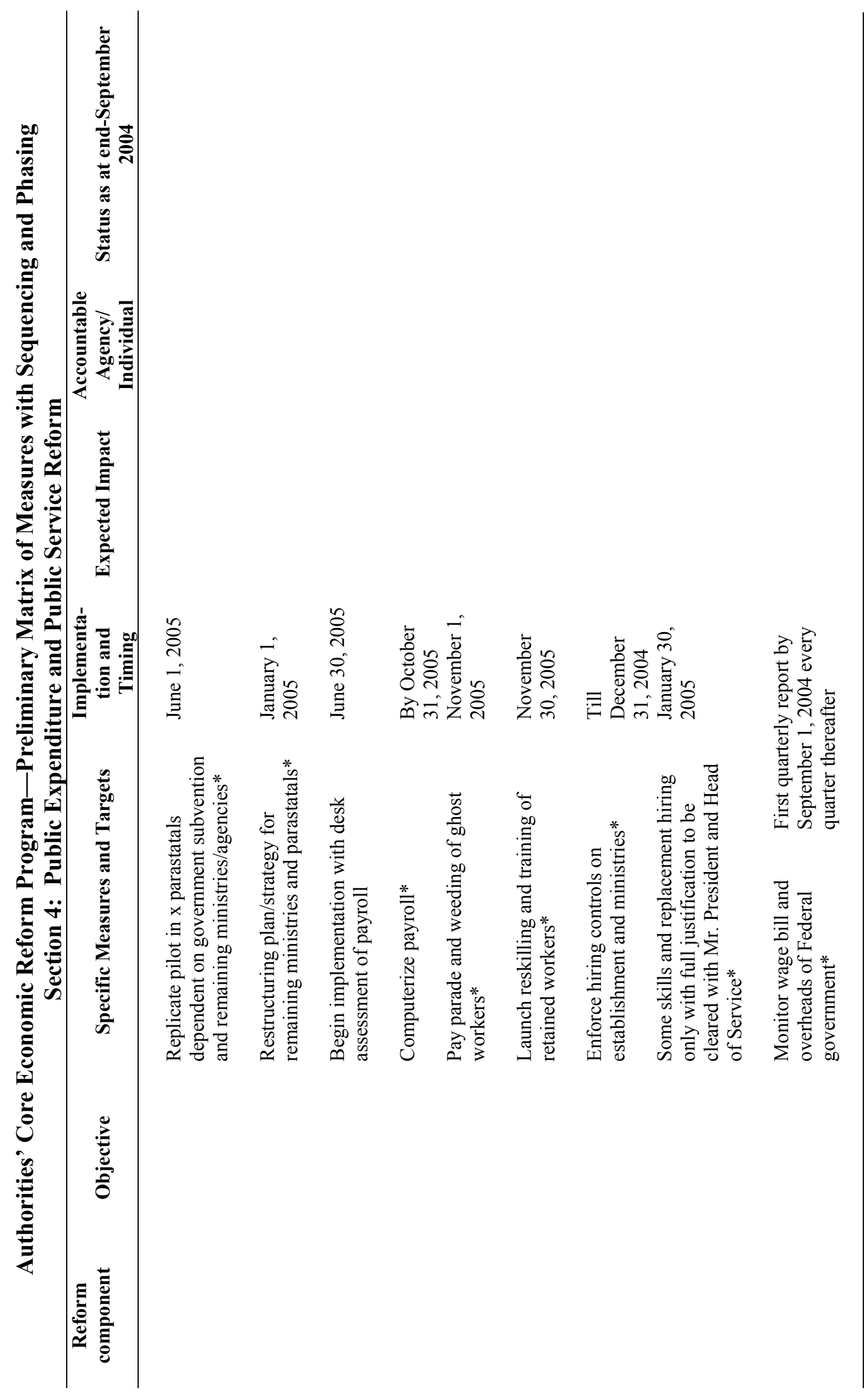




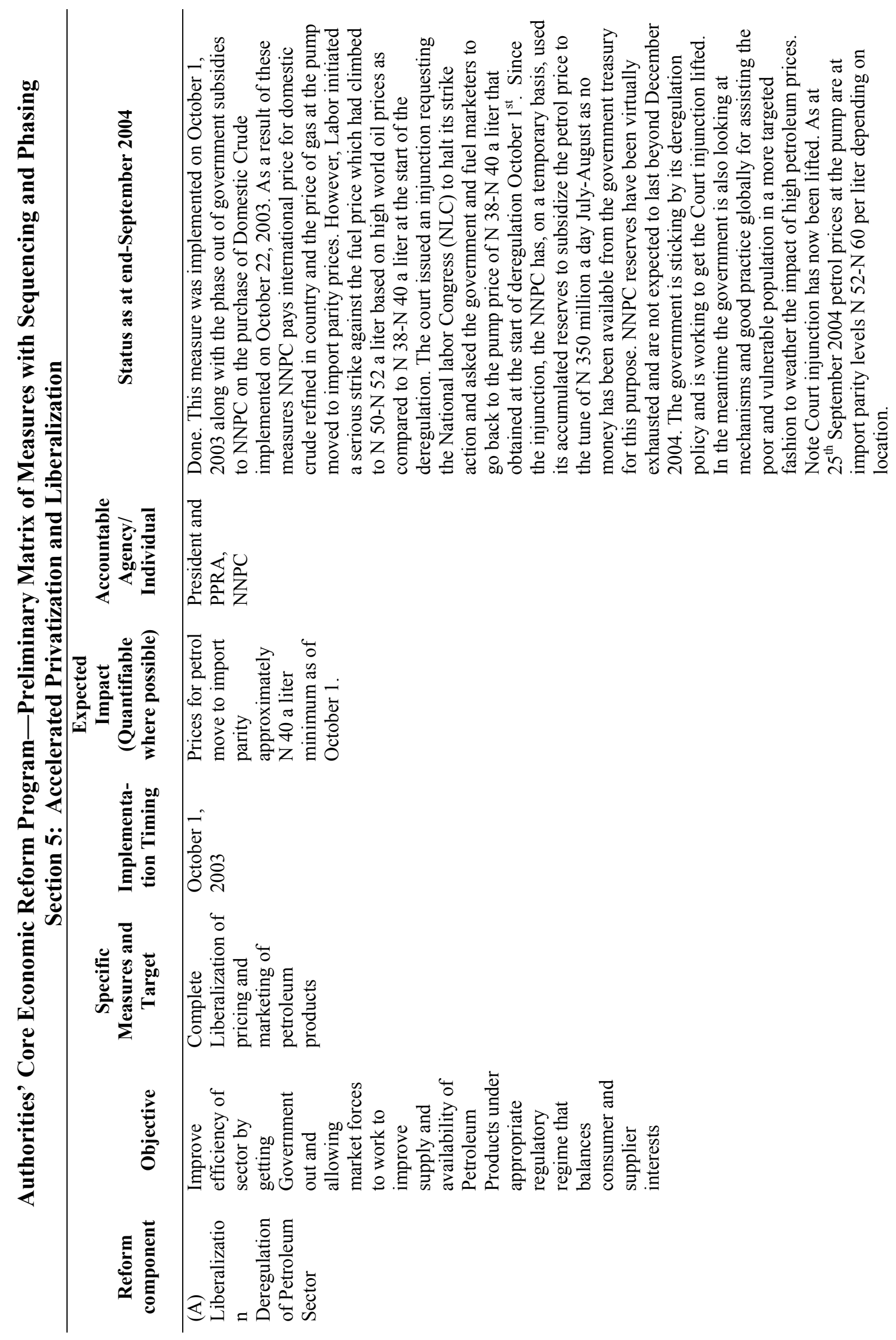




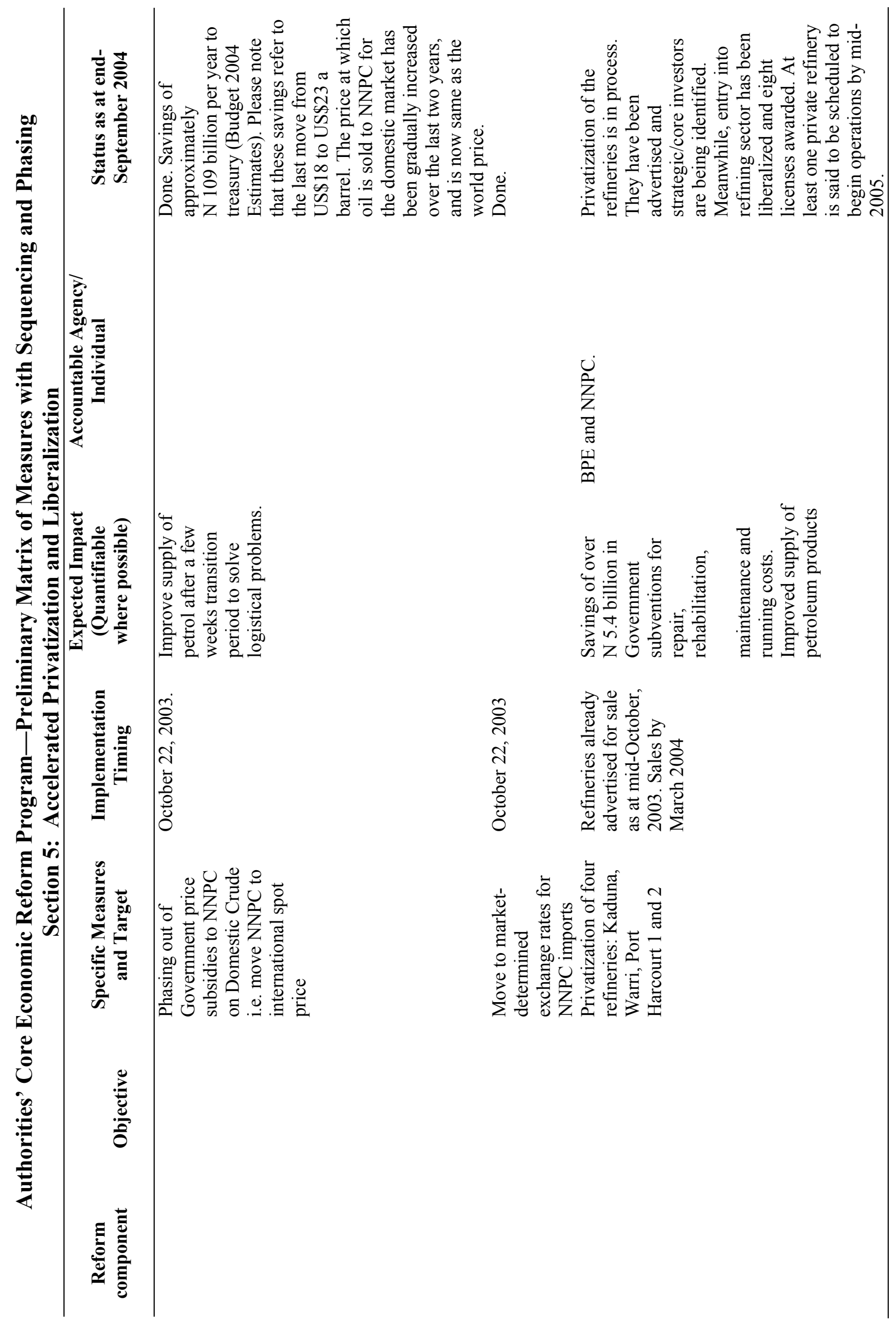



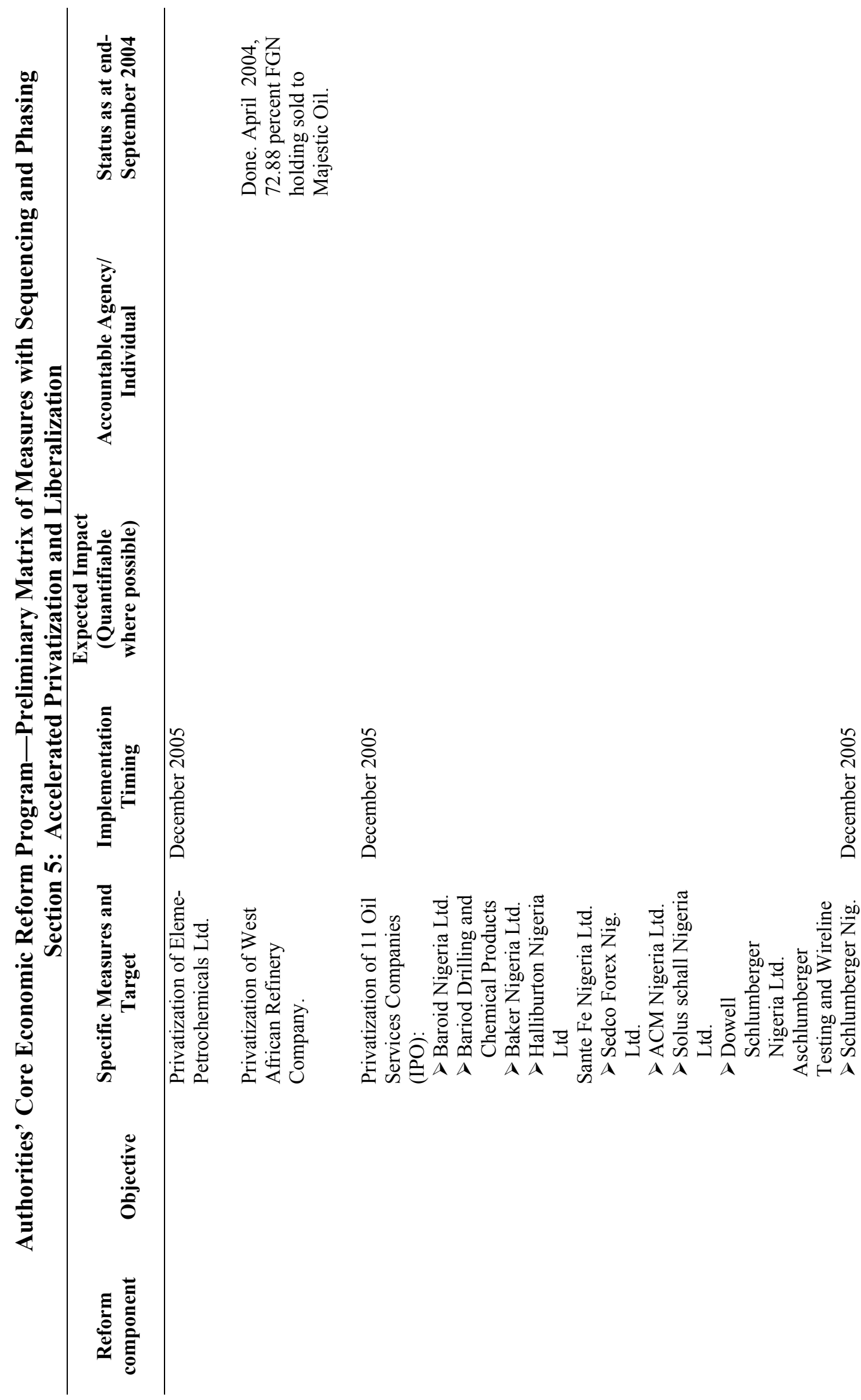

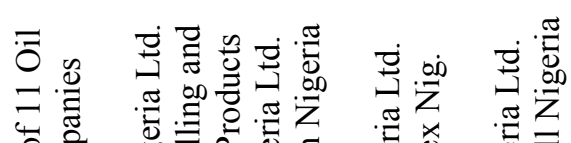

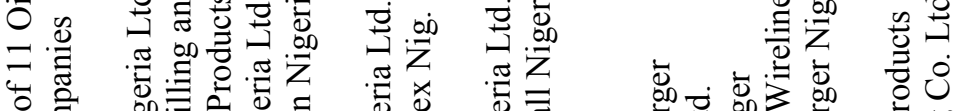

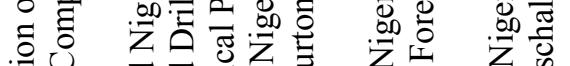

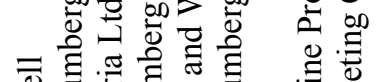
. 芯

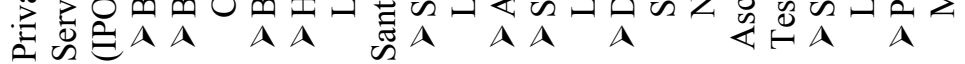




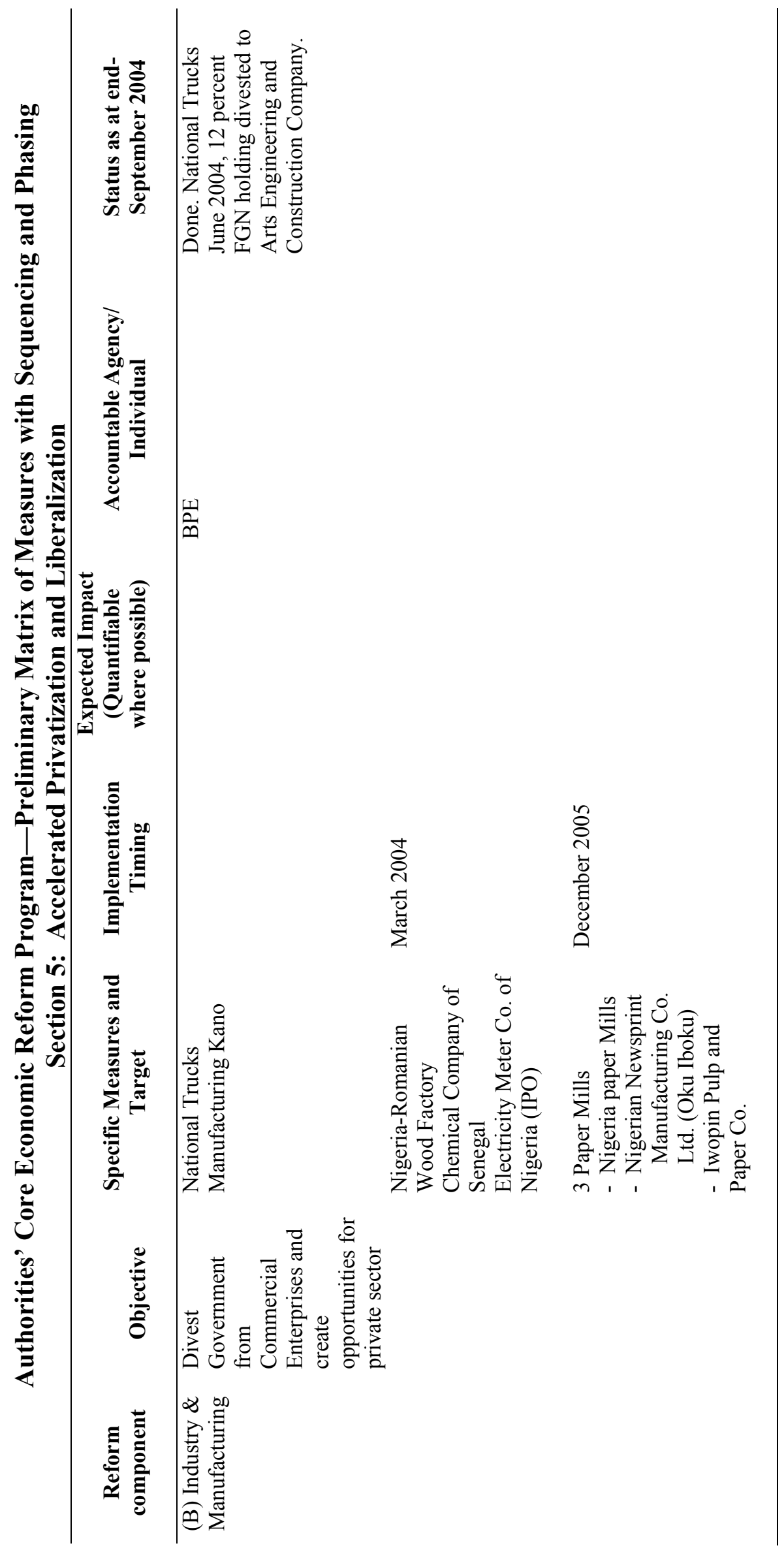




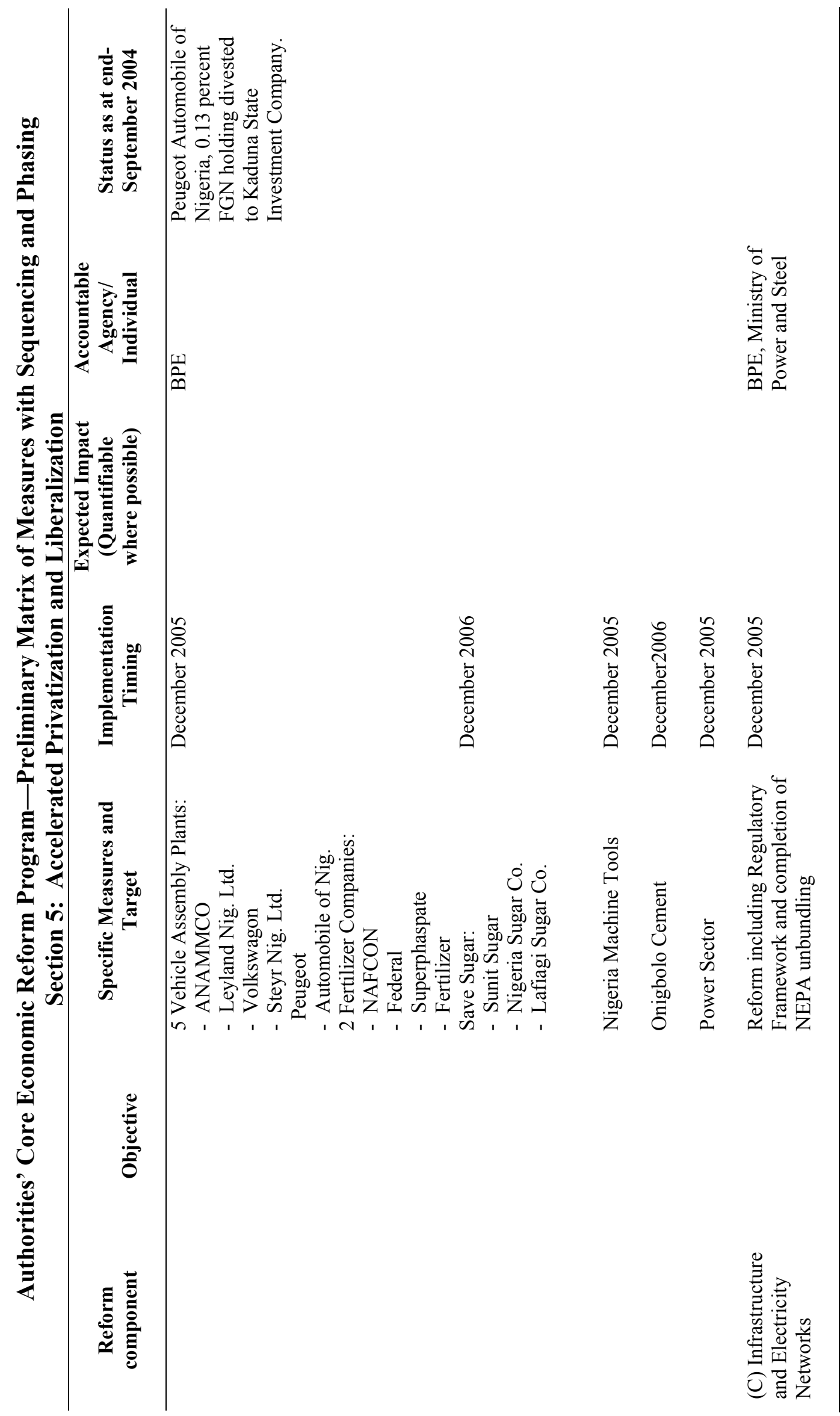




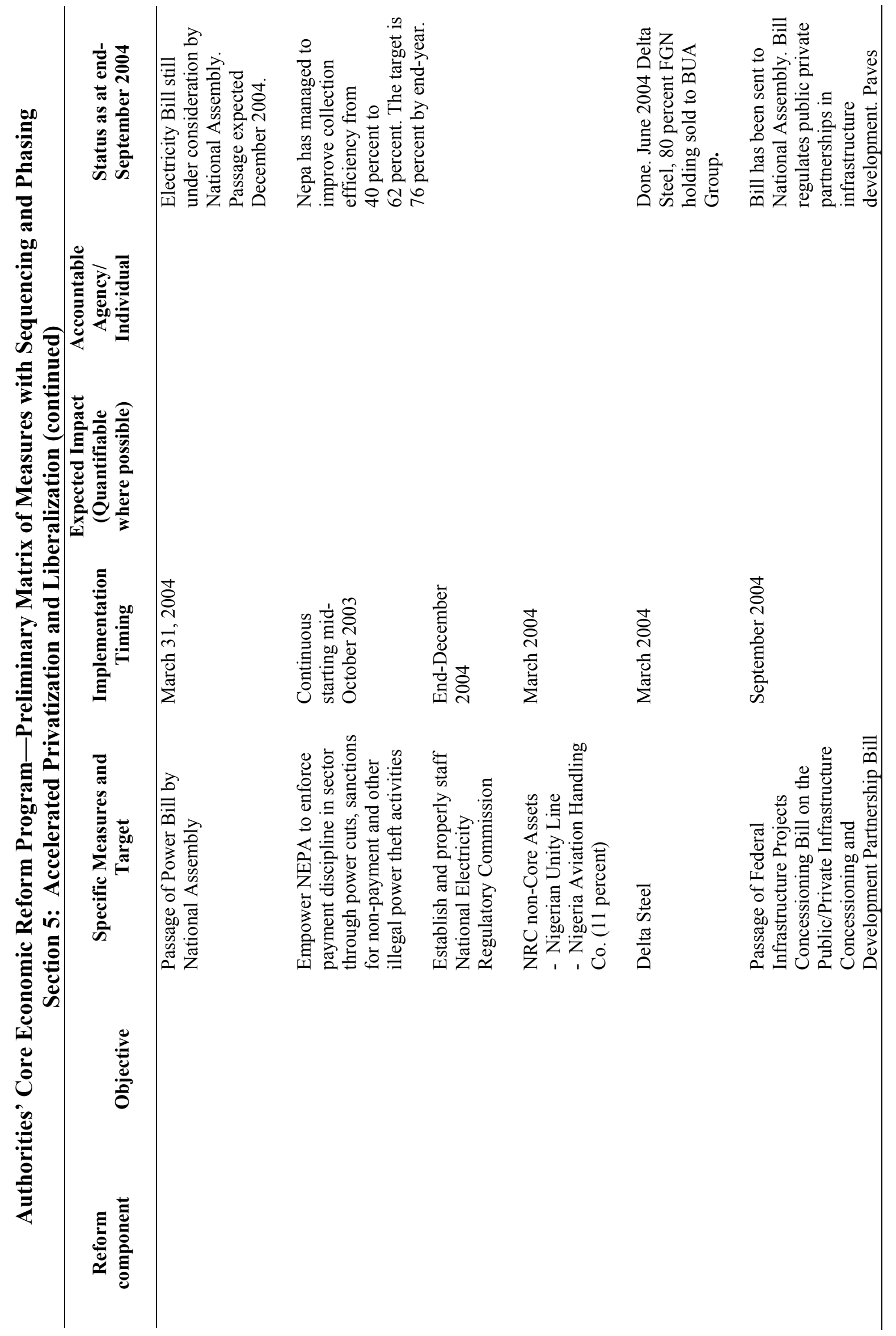




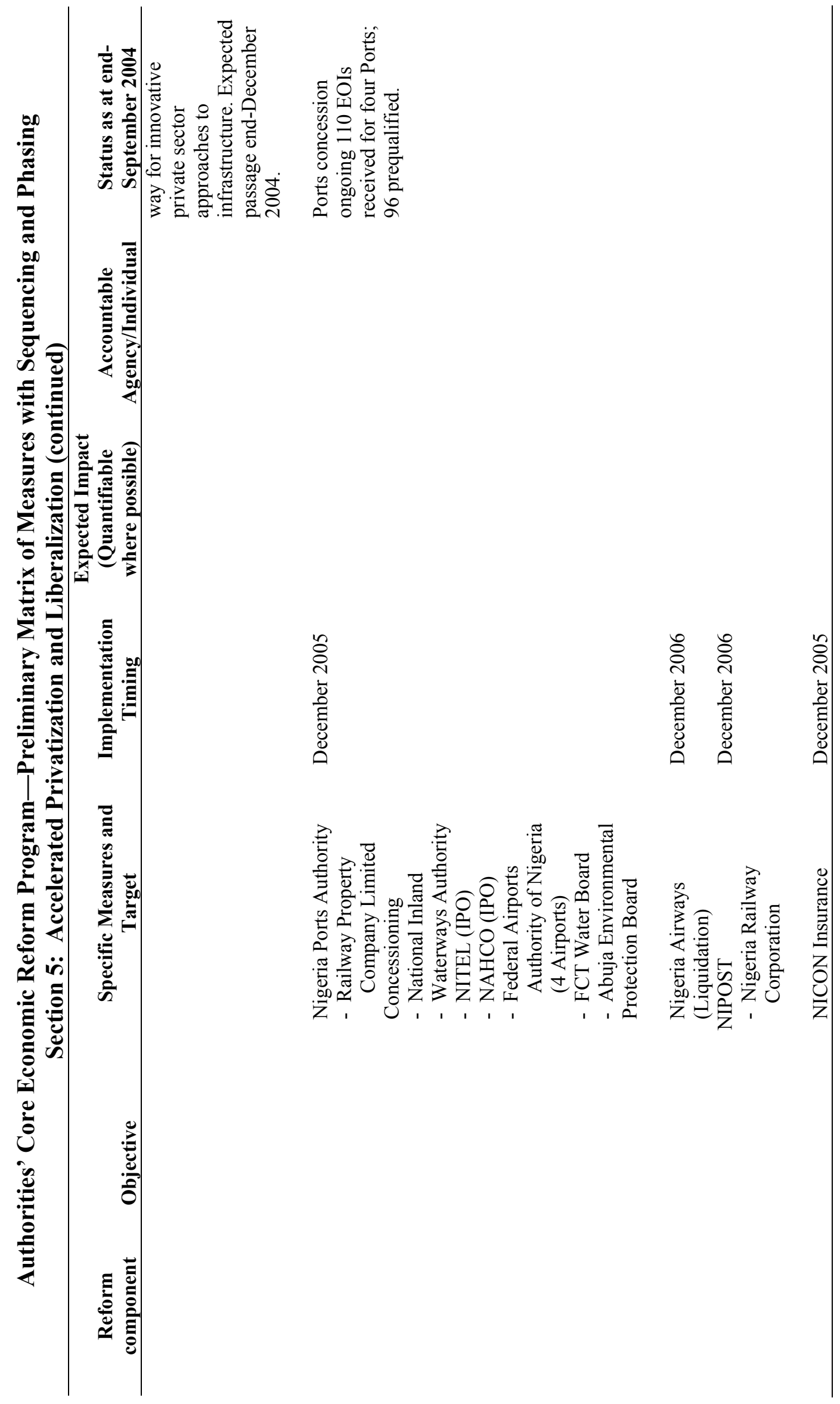




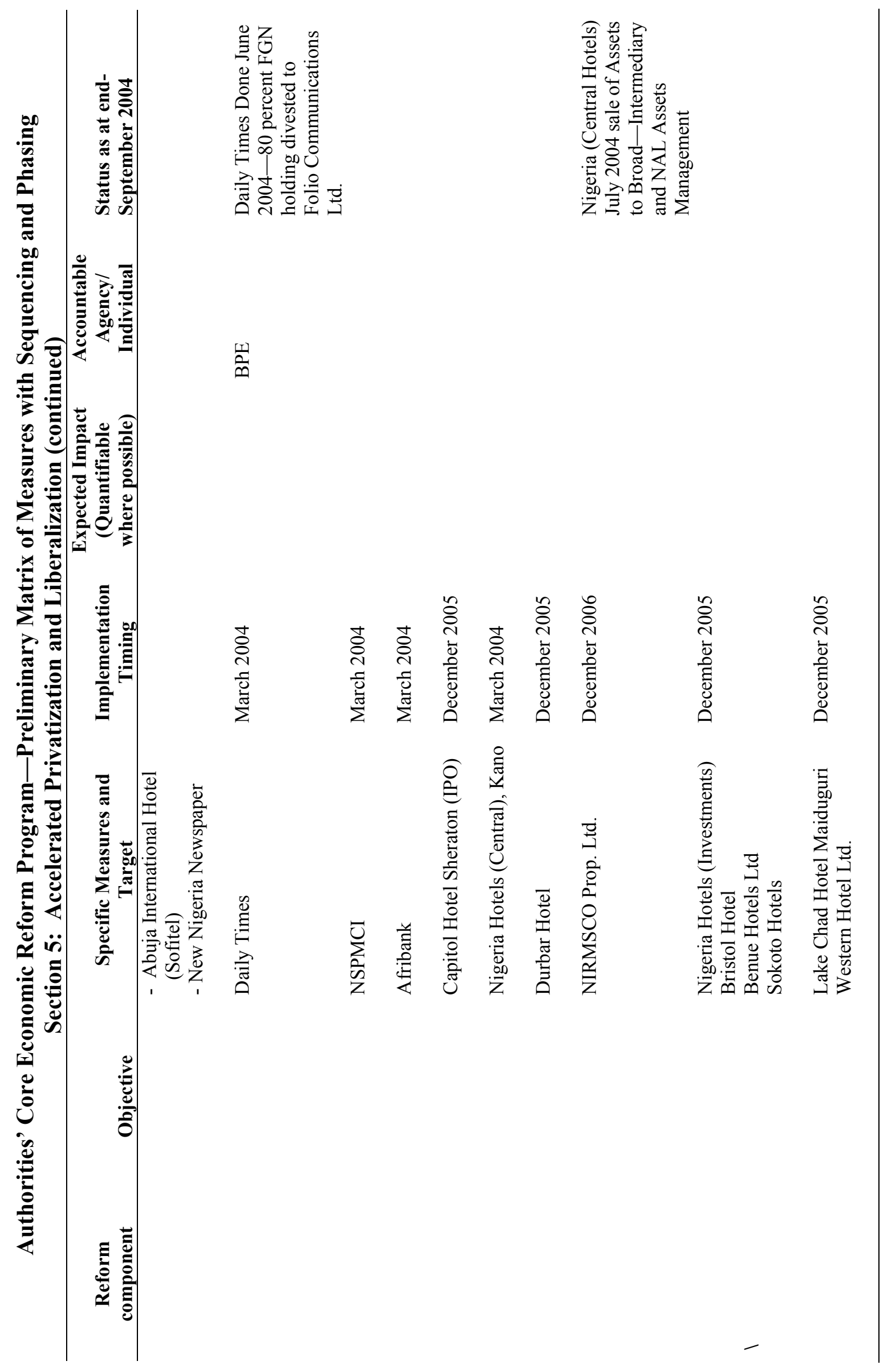









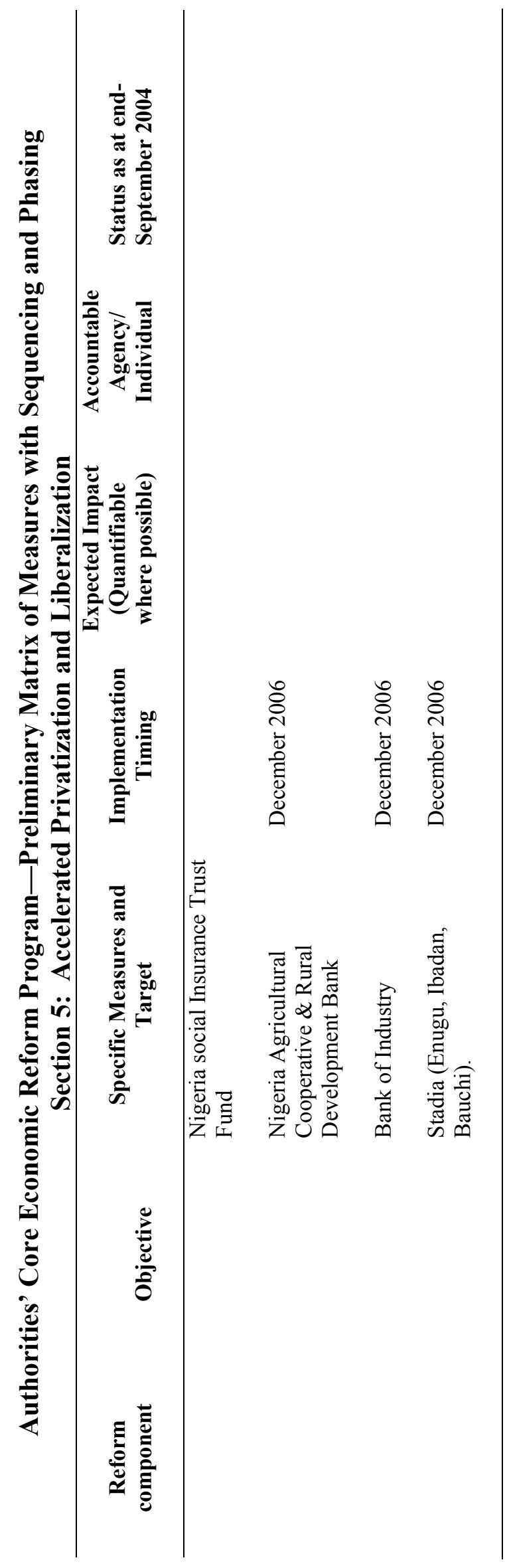


Nigeria: Tentative Work Program, 2005-06

Item Date

Review of developments at end-2004 and 2005 February/March 2005

Article IV consultation discussions.

Review of developments during the first quarter May 2005

of 2005 and prospects.

Mid-year review for 2005.

August/September 2005

Review of developments for the third quarter of

November 2005

2005.

Review of developments for end-2004 and 2005 February/March 2006

Article IV consultation discussions. 